
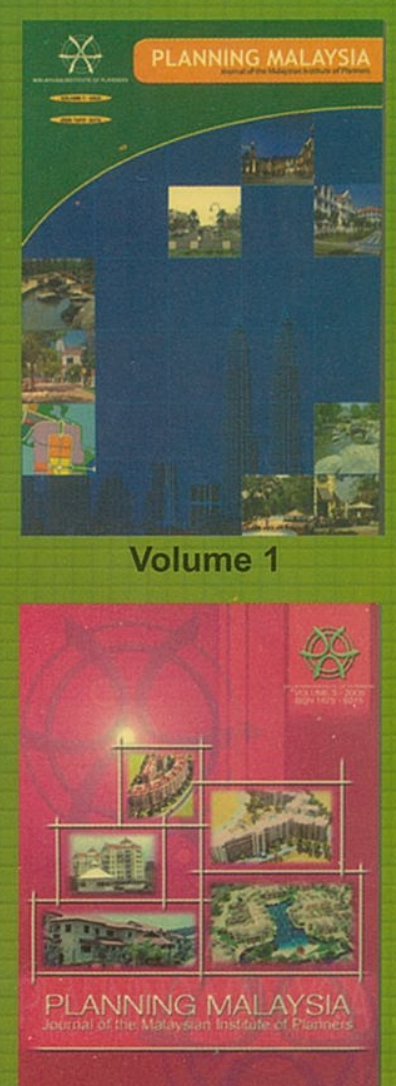

Volume 3
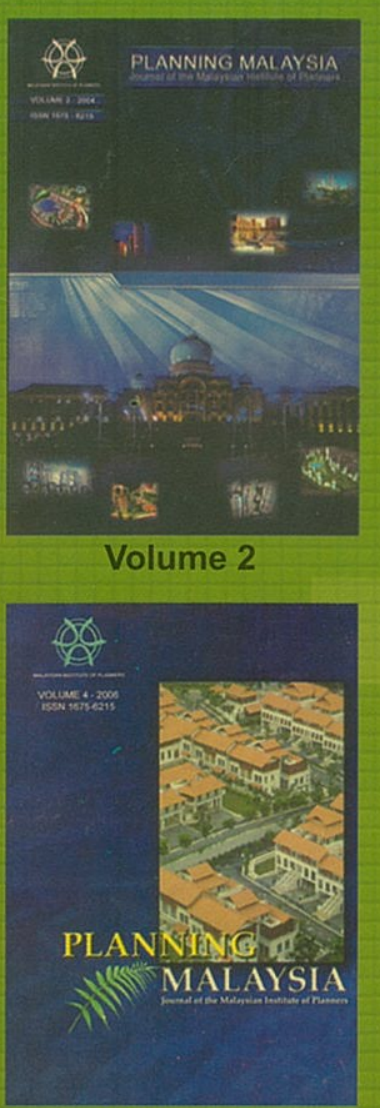

Volume 4

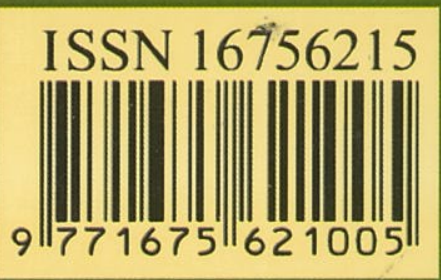

PLANNING MALAYSIA Journal of the Malaysian Institute of Planners

B-01-02, Jalan SS 7/13B, Aman Seri, Kelana Jaya 47301 Petaling Jaya, Selangor Darul Ehsan, MALAYSIA

Tel : (603) 7877-0637,7877-0636_Fax: (603) 7877-9636_Email : mip@mip.org.my

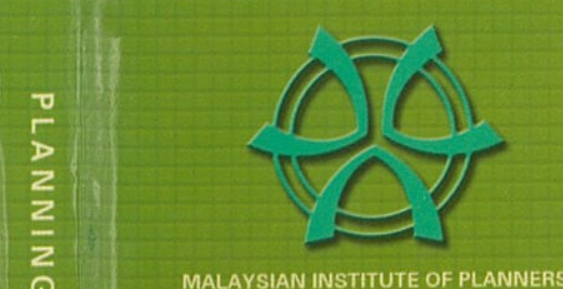

VOLUME $5-2007$

ISSN 1675-6215

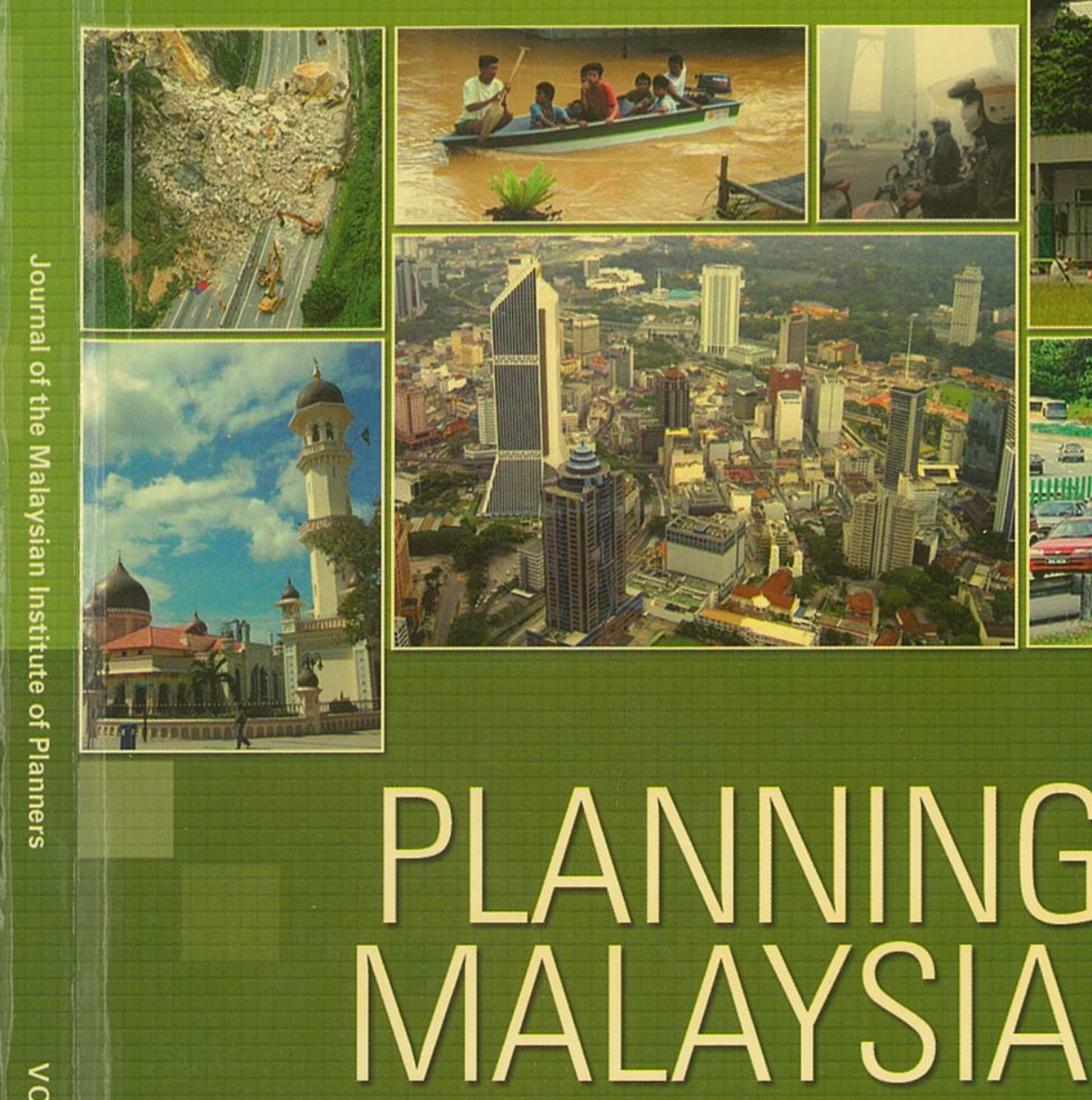

Journal of the Malaysian Institute of Planners

www.mip.org.my 


\section{PLANNING MALAYSIA}

Journal of the Malaysian Institute of Planners

\section{Advisor}

Norliza Bt. Hashim

Editor-in-Chief

Professor Dr. Alias Abdullah

Editorial Board

Professor Dr. Mansor Ibrahim

Dr. Mohamed Thalha Alithamby

Assoc. Professor Dr. Lee Lik Meng

Assoc. Professor Dr. Ho Chin Siong

Assoc. Professor Dr. Jamalunlaili Abdullah

Khairiah Bt. Hj. Mohd Talha

\section{Editorial \& Business Correspondence}

PLANNING MALAYSIA

Journal of the Malaysian Institute of Planners

B-01-02, Jalan SS7/13B, Aman Seri, Kelana Jaya

47301, Petaling Jaya, Selangor Darul Ehsan, MALAYSIA

Tel: +60378770637 Fax:+60378779636 Email:mip@mip.org.my

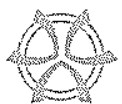

\section{Copyright $(\mathrm{MIP}, 2007$}

All rights reserved.

No part of this publication may be reproduced, stored in a retrieval system, or transmitted in any form or by any means, electronic, mechanical, photocopying, or otherwise without the prior permission of the publisher.

The views expressed in this publication are those of the author(s) and do not necessarily represent the views of MIP.

\section{Published By}

Malaysian Institute of Planners

ISSN Number

1675-6215 


\section{MIP Council Members}

(2005-2007 Session)

\section{President}

Norliza Bt. Hashim

Vice President

Professor Dr. Mansor B. Ibrahim

Hon. Secretary

Ahmad Suhaimi b. Ismail

Hon. Treasury

Mohd Nazri Mohd Noordin

Council Members

Professor Dr. Alias Abdullah

Jason Lee Poh Lee

Khairiah Bt. Talha

Assoc. Professor Wan Mohamed Yusoff

Ihsan Zainal Mokhtar

Mohd Zambri Husin

Ex-officio

Mohamad Nazri B. Jaafar

Co-opted Members

T. Mahesan

Dato' Zainuddin B. Muhammad

Datin Paduka Dr. Halimahton Saadiah Bt. Hashim

Ahmad Zamri B. Kamaruddin

Zainab Bt Mohd. Ghazali

Dato' Hj. Zainol B. Hj. Ayob

\section{Chairman of Sarawak/Sabah Chapter \\ Affandi Keli \\ Chairman of Northern Region Branch \\ Tan Thean Siew}

Chairman of Southern Region Committee

Mohd Anuar B. A. Wahab 


\section{CONTENTS}

Message from The President

iii

\section{Articles:}

1. Effectiveness of Public Participation Programme: A Feedback from Participants (Sabak Bernam District Local Plan and Kuala Lumpur Structure Plan)

By: Dasimah Omar \& Oliver Ling Hoon Leh

2. Multicriteria Analysis of Flood Causes in Kuala Lumpur By: Nur Fazzillah Muhamed Noordin, Alias Abdullah \& Muhammad Nur Azraei Shahbudin

3. Urban Housing Development: Town Planning Issues By:Ibrahim Mohd@Ahmad, Ezrin Arbi \& Ahmad Ramly.

4. Sustainable City Planning: Emphasis on The Management of Environmentally Sensitive Areas

By: Halimaton Saadiah Hashim, Joy Jacqueline Pereira \& Ibrahim Komoo

5. The Environment Component in Sustainability Assessment at The Local Level Plan

By: Abdul Hadi Harman Shah, Shaharudin Idrus \& Abdul Samad Hadi.

6. Developing a Communicative Planning Approach to Resolve Land Use Conflicts in Jelutong Area of Georgetown, Penang, Malaysia

By: Mohammad Abdul Mohit \& Raja Mohd. Firdous B. R.M.

Harun

7. Komuniti Mapan: Penilaian Tahap Kemapanan Komuniti Orang Asli Temiar Di Negeri Perak

By: Khairul Hisyam B. Kamarudin \& Ibrahim B. Ngah

8. Book Review: "The Boulevard Book"

By: Shu Charng Yen

Notes to contributors and guidelines for manuscript submission.......

"Whoever travels in search of knowledge is on Jih?d until he returns"

(Transmitted by Tirmidhi \& Darimi)

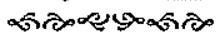




\section{MESSAGE FROM THE PRESIDENT}

\section{Dear Readers,}

MIP is once again proud to produce its fifth volume of Planning Malaysia. It is indeed a great achievement to the Institute as we strive to encourage members to write and share new ideas on planning and urban development.

The wide ranging topics in this journal reflect the various dimensions of urban planning that is holistic and comprehensive. One of the key objectives of this journal is to provide a platform for town planners to share new ideas and experiences on urban planning. Such new ideas are by research, studies undertaken or actual hands-on experiences of planners. Thus we hope this journal provides a better insight to all readers of the broad dimensions that urban or town planning has and the role town planners play in growth and development of the nation.

Planning Malaysia is Malaysian Institute of Planners gift to the industry and to date we have extended the journal to various planning related organizations, institutions of higher learning as well as to all members of the Institute. We hope to eventually extend the circulation of this journal to non-planning related organisations and institutions that play an indirect role in planning within and outside the country as we hope to share the Malaysian experience with as many others.

Congratulations once again to the Editor-in-Chief, Dr Alias Abdullah and his team of Editorial Board for the dedication and continuous support to the Institute

Thank you.

Norliza Bt. Hashim

PRESIDENT

(2005-2007) 


\author{
PLANNING MALAYSIA \\ Journal of the Malaysian Institute of Planners (2007) V, 1 - 16
}

\title{
EFFECTIVENESS OF PUBLIC PARTICIPATION PROGRAMME: \\ A FEEDBACK FROM PARTICIPANTS \\ (SABAK BERNAM DISTRICT LOCAL PLAN AND KUALA LUMPUR STRUCTURE PLAN)
}

\author{
Dasimah Omar ${ }^{1} \&$ Oliver Ling Hoon Leh ${ }^{2}$ \\ Faculty of Architecture, Planning and Surveying \\ UNIVERSITI TEKNOLOGI MARA, MALAYSIA
}

\begin{abstract}
Nowadays, public awareness on the potential dangers of environmental problems and the negative impact from the development has been increasing. Public has the right to know and participate in making decisions, particularly in those have potentially affect on the communities in which they live and work. Furthermore, Malaysia is adopting the Rio Declaration - Sustainable Development and Agenda 21. One of the fundamental prerequisites for the achievement of sustainable development is broad public participation in decision-making. Research had been carried out to identify the effectiveness of the public participation programme for Sabak Bernam District Local Plan 2002-2015 and Kuala Lumpur Structure Plan 2020. The research was carried out by collecting feedback from the participants of public exhibitions and workshops for both of the plans. Through the research, it was found that series of workshops are the effective method of public participation for development plan as compared to public exhibition after draft proposal of the plan has been completed. An effective and successful public participation programme should allow members of the community to have an active voice in the process and to have a free access to important information
\end{abstract}

Keywords: Public Participation, District Local Plan, Structure Plan, Effectiveness

\section{INTRODUCTION}

Some major ecological disasters which caused heavy losses had a great impact on the development of public participation. These disasters have made the

\footnotetext{
${ }^{1}$ Ph.D., Associate Professor of Town \& Country Planning Department, UiTM. She can be contacted at dasimaho@yahoo.com.

${ }^{2}$ Lecturer of Town and Country Planning Department, UiTM. He can be contacted at oli761@yahoo.com.
} 
public increasingly aware of the potential dangers of environmental problem, and therefore insisted on better and safer regulations and more openness in matters of ecological importance. Authorities were forced to involve citizens in the decision making process and to provide more access to information. In many countries, this led to special legislation in this field. In the United States, the Right-to-Know Acts were expanded after the Bhopal disaster, which included the obligation to provide information for the people living in the neighbourhood of chemical and other heavy industrial plants regarding the dangers threatening them. In this way an effective emergency plan and management system could be designed.

The public have the right to know and participate in decision making. One of the fundamental prerequisites for the achievement of sustainable development is broad public participation in decision-making. "Environmental issues are best handled with the participation of all concerned citizens, at the relevant level" (Principle 10, the Rio Declaration). It was in line with our survey that was carried out in year 2003 and 2004. We found that most of the respondents believed that effective public participation programme would increase environmental quality.

Generally, public participation has many advantages to both citizens and planning authorities (and decision makers). Some of the advantages are:

\section{For Citizens / Public:}

- The opportunity to share their opinions, criticise and influence public decisions in relation to the future planning.

- The opportunity to learn other citizens' perspectives that take into account environmental, social and economic considerations.

- The freedom of speech and to be heard.

- The opportunity to reach consensus.

- The opportunity to collect background information of their areas and information on the future planning of their areas.

- The opportunity to contribute towards better environment for their living and working area.

- Increase the public ability to understand the planning process.

2. For Decision-Makers and Planning Authorities:

- The opportunity to communicate with a variety of people especially at the grass-root level.

- The opportunity to strengthen the quality of decisions and final plan.

- The opportunity to access more information. 
- The opportunity to achieve and demonstrate more transparency in the planning decision-making process.

- The increase in the level of public acceptance on government's plan and decision.

As mentioned by Ortolano (1984), the public hearing is the most rigid. A hearing officer generally governs the proceedings and a stenographer makes a verbatim transcript. Presentations are formal and there is little interaction among participants. Large group meetings can be much less formal than hearing. However, it is difficult for many citizens to contribute directly in large assemblies unless provisions are made to break them up into small discussion groups.

In order to move towards more sustainable development, there is a need to identify and increase the effectiveness of public participation programme. The effective public participation programme will increase the level of cooperation between planning authorities and public to achieve their similar planning goal, which will benefit all people.

A research had been carried out to identify the effectiveness of the public participation programme for Sabak Bernam District Local Plan 2002-2015 (SBDLP) and Kuala Lumpur Structure Plan 2020 (KLSP). The research was carried out by collecting feedback from the participants of public exhibitions and workshops for both of the plans.

\section{OBJECTIVES}

There are three main objectives of this study:

i. To identify the basic principles and requirements for effective public participation programme.

ii. To analyse the effectiveness of the public participation methods currently practiced in the development plan preparation process.

iii. To identify the appropriate methods, approaches and principles for more effective public participation for the study area.

\section{METHODOLOGY}

This research involved the collection of primary and secondary data. SPSS software was used for data analysis. The research was based on a set of questionnaire. A total of 51 respondents were interviewed for the SBDLP and 
another 31 respondents for KLSP through a return mailed questionnaire. Secondary information was collected from the related agencies through interviewing the officers.

\section{REQUIREMENTS UNDER THE ACTS}

\section{Public Participation in the Preparation of Local Plan under Act 172}

The new provision of Town and Country Planning Act 1976 (Act 172), under Section 12A, stated that before commencing the preparation of a local plan, the local planning authority shall take such steps as will in its opinion secure:

(a) that publicity is given in its area to the draft local plan that will be prepared, its objection and the purpose for its preparation, and matters that the local planning authority proposes to include in the plan;

(b) that persons who may be expected to desire an opportunity of making representations to the local planning authority in respect of those matters are made aware that they are entitled to, and are given, an opportunity of doing so.

Section 12A does not limit the period for public to make representations. However, Sabak Bernam District Council has organised few workshops and exhibitions for public to participate in the Sabak Bernam District Local Plan making process; starting from early stage until end of the plan preparation.

Under the Section 13 of the Act, when the local planning authority has prepared a draft local plan, it shall, before adopting a draft local plan, but not before the structure plan, make copies of the draft local plan available for inspection at its office and at such other places as it may determine for not less than 4 weeks. Beside, objections to or representations in respect of the draft local plan may be made to the local planning authority.

Under the Section 14, Act 172, for the purpose of considering objections to and representations in respect of a draft local plan, the local planning authority may cause a local inquiry or other hearing to be held by a committee of 3 persons appointed by the State Planning Committee (SPC).

According to Section 15, Act 172, after considering the objections or representations, the local planning authority shall submit the draft local plan or the draft local plan as modified so as to take account of the objections or representations or of any matters arising therefrom, to the State Planning 
Committee for its approval. Therefore, local planning authority is not required under the Act 172 to follow strictly the public objections or representations, local planning authority is required to consider or 'take account' of the objections or representations.

\section{The Sabak Bernam District Local Plan 2002-2015 (SBDLP)}

SBDLP is the first Local Plan prepared under the provision of Section 12a, Town and Country Planning (Amendment) Act 2001. The public participation programmes were held at every stage of SBDLP preparation process, which started with:

a. A workshop and exhibition at the early stage of study (Seranta Awal); followed by

b. A workshop after the technical report was prepared;

c. A workshop after draft proposal was prepared; and

d. An exhibition after the draft proposal had been amended.

Additional to this, the method of public participation has been modified from 'public exhibition' and 'public hearing' to 'workshops', 'public exhibition' and 'public hearing' (see Photo A, B, C, D, and E).

\section{Public Participation in the Preparation of Kuala Lumpur Structure Plan under Act 267}

Kuala Lumpur Structure Plan 2020 had been prepared under the provision of Federal Territory (Planning) Act 1982 (Act 267). Under the provision in Section 7 , Act 267, after the draft structure plan has been prepared, public can inspect and purchase copy of draft structure plan, and able to make objections in writing within the period not less than one month as per mentioned in gazette and local newspapers. For the purpose of considering and reporting any objection, Minister shall appoint a Committee. In considering any objection, the Committee shall as soon as practicable hear any person including representatives of Government Department or statutory bodies who in filing the objection has made a request to be heard.

Under the same Section, sub-section 7, the Commissioner also didn't required to follow strictly the objections, but only "shall consider the report of the Committee and may make such amendments to the draft structure plan as he considers proper ...". 


\section{The Kua'a Lumpur Structure Plan 2020 (KLSP)}

The KLSP still applies the methods of 'public exhibition' and 'public hearing' for the public to participate after the draft KLSP was prepared. Besides the public exhibition, Kuala Lumpur City Hall also had given special briefing to a number of organisations based on request. Kuala Lumpur City Hall had organised road shows at some strategic locations such as KLCC Suria shopping complex, Mid Valley shopping complex, Selayang and KL Central (see Photo F, G and H). Kuala Lumpur City Hall had also put the draft KLSP in the city hall's web site ${ }^{3}$ for public viewing and reading. For the purpose of effective publicity, it was discovered that the City Hall had spent a lot of money for advertisement through television programmes, banners and newspapers, on-line reports and video presentations.

\section{ANALYSIS AND FINDINGS}

The analysis involved analysing of feedback from the respondents who were involved in public participation in the Kuala Lumpur Structure Plan 2020 and Sabak Bernam District Local Plan 2002-2015. Microsoft Excel and SPSS software were utilised in the analysis of primary data. In this study, the analysis was carried out by computing the feedbacks from respondents separately for these two development plans. Feedbacks of respondents have been studied to identify the effectiveness of the overall programmes and the effectiveness of each main aspect or element of public participation. The effectiveness of these two development plans' public participation programmes are discussed together but not for the purpose of direct comparing due to the different characteristics of both plans and programmes.

From the survey, it was found that, the highest aspects of concern for most of the respondents were infrastructure and public facilities development, future economic development, and environmental issues and quality. In general, all respondents for SBDLP felt that, the public participation programme was effective. However, for KLSP, there were $23.3 \%$ of the respondents who felt that the public participation programme was not effective.

For SBDLP, the effectiveness of the programme also includes the use of banners and effective presentations (only $6.0 \%$ of the respondents said that the banners and presentations were not effective) and the information was clearly understood by respondents. Besides that, the public participation programme

\footnotetext{
${ }^{3}$ See http://pskl2020.dbkl.gov.my.
} 
managed to deliver enough relevant information to participants, used effective methods of publicity and effective methods for participants to give ideas, opinions or comments. The methods used in the public participation programme included written comments and oral discussion during the workshop.

In addition, the programme had successfully made the participants believe that the government would consider their opinions seriously in the process of preparing the plan. Most of them felt that they have equal rights and chances of getting information.

Other factors contributed to the effectiveness of the public participation programme for SBDLP were:

a. The limitation of the SBDLP was clearly explained by the study team during the workshop. As a result, the participants received better understanding regarding the scope of the discussion.

b. Majority of the respondents received response from the government on their decision, as well as the reasons for accepting or rejecting the public opinions that was done through the two-way communication during the workshop.

c. Participants were guided by the study consultants or professional planners effectively during the workshop.

Nevertheless, the public participation programmes had faced few weaknesses as described here:

a. The programme failed to deliver enough information on the future development of the area to the participants. The public were expecting more details or comprehensive information on the future development for their areas.

b. The development constraints were not presented clearly, lack of detailed information and not specific for the public to understand.

For KLSP, the public participation programme was less effective. This was shown in the survey data where $23.3 \%$ of the respondents felt the programme was not effective. These included the use of banners and presentations. There were $26.7 \%$ of the respondents mentioned the banners and presentations were not really effective and another $33.3 \%$ of the respondents could not understand the information provided in exhibition or report. Here, the public participation programmes had failed to deliver enough relevant information to the majority of the participants in the campaign. 
Besides that, the method used in giving ideas, opinions or comments by participants also was less effective. The programme was not successful in delivering enough information on the future development of the area during the public exhibition. One third $(33.3 \%)$ of the respondents felt that the written form method used was not effective. The study shows $61.3 \%$ of the respondents from KLSP believed the government would not consider their opinions or comments seriously, and $50 \%$ of the respondents felt that they did not have equal rights and chances on planning and development of Kuala Lumpur. However, the publicity of the programme was carried out effectively.

Other factors contributing to the ineffectiveness of the public participation programme for KLSP were:

a. The information on the environmental quality was not presented/delivered clearly, lack of detailed information and not specific for the participants.

b. The limitation of the KLSP and the development constraints were also not presented clearly, lack of detailed information and not specific enough for the participants.

c. Majority of the respondents stated that they did not receive response from the City Hall on final decision as well as on reasons for accepting or rejecting their opinions. As a result, the respondents' belief the government would not consider their opinions seriously.

d. Technical advice given by the Kuala Lumpur City Hall personnel (i.e. the town planners) was not comprehensive enough. Some of the participants did not get the technical advice. This might affect their understanding on the information or plans presented.

\section{RECOMMENDATION AND CONCLUSION}

\section{a) Effective methods through series of workshop and public exhibitions}

From this study, it was found that organizing series of workshops was a more effective method of public participation as compared to having one public exhibition after the draft proposal or plan has been completed. This is because an effective and successful public participation programme should allow members of the community to have an active voice in the process and to have free access to important information. Besides that, through the workshop (the two-way communication) it could: 
a. Create a dialogue session that provides feedback;

b. Easily establish trust and credibility in the community;

c. Give input and discuss issues with stakeholders and related groups or people;

d. Ensure the planning authority to fulfill their obligations on the needs of the public, in particular the participants;

e. Let the public be involved in the early process, receive feedback and address them before making decisions;

f. Give opportunities to participants to understand the preparation of plan and to give input directly to the study team starting from the beginning of the plan preparation process;

g. Let the planners and the public understand and respect each others' values and limitations through direct two-way communication;

h. Make all segments of the interested community to have an equal opportunity to receive information and participate in the process through open discussion and written form;

i. Let the planning authority and planners evaluate the effectiveness of the programme after every workshop or discussion session;

j. Allow the planning consultants/authority to give direct response to the public or participants on the issues or views highlighted; and

k. Give opportunities to participants to ask and to get more information from planners.

The series of workshops and public exhibitions should be organised from the beginning of the plan preparation to the final stage of the process, which include:

a. Workshop at the early stage (before the start of the plan preparation);

b. Workshop and public exhibition after the technical report has been prepared; and

c. Workshop and public exhibition after the draft proposal has been prepared.

These workshops should be participated by the planning authority, planners, all the stakeholders and general public. Workshop at the early stage should aim at getting the public informed about the purpose, scope and the importance of the plan making. Besides that, the workshop should give opportunity to the public and stakeholders to give their opinions and views before the preparation of the plan by the planning authority and consultants. 
The workshops and public exhibitions should be held at strategic locations, such as public hall, town square and public transport terminal. The criteria of good location are:
a. High accessibility via public transport system and roads,
b. Public focus area or community centre, and
c. Ample and suitable space for various activities/purposes.

\section{b) Establish public trust}

According to the feedback from respondents, the government (planning authority) is the proper agency to act as an organiser for the public participation programme. However, the organiser of the public participation programme should consider the following actions to increase the public trust upon the organiser:

a. Establishing trust and credibility in the community through honesty and openness;

b. Involving the public early in the process, receiving feedback, and addressing public concerns before making decisions;

c. Understanding and respecting the values and limitations of participants;

d. Providing sufficient information on the development objectives, issues, challenges and potentials, existing environmental quality, positive and negative impacts of the proposed plan, and the limitations of the development plan for public / participants;

e. Inviting everyone to participate and giving equal opportunity to all participants;

f. Showing high appreciation to the participants using appropriate approach, such as a letter of appreciation informing them the actions taken by the planning authority on their opinions, comments or views.

\section{c) Improve the effectiveness of the public participation programme}

There are other proper actions that could be taken by the organiser to improve the effectiveness of the public participation programme. These include:

a. Evaluating the best types of activities for the community to participate;

b. Planning the public participation activities ahead of time, allowing flexibility for changing interest levels in the community; 
c. Taking steps, such as issuing multilingual fact sheets or encouraging the formation of citizen advisory groups, to ensure that all segments of the interested community have an equal opportunity in receiving information and participating in the process;

d. Using simple and suitable language and also appropriate format of presentation (report, banner and multimedia presentation);

e. Educating the public regarding the purpose, importance and scope of the development plan, as well as the right, obligation and the proper ways for public to participate;

f. Giving detail explanation to the public / participants before they are divided into smaller groups for effective discussion;

g. Providing sufficient number of planning advisors during the workshop and public exhibitions;

h. Allowing participants to give their comments, opinions or views in both oral and written form;

i. Setting up more places for exhibition, including the access to on-line exhibition;

j. Evaluating periodically on the effectiveness of the public participation programme;

k. Using video recording to record the public views and comments;

1. Providing mobile exhibition room and more venues for public exhibition, such as in housing areas, shopping centres, hospitals, public transport terminals / stations, public halls and high learning institutions;

m. Providing on-line public participation;

n. Providing free parking fee and special discounted public transport fare for participants;

o. Educating public on the importance of public participation in planning process; and

p. Providing longer period (more than one month) for public exhibition and it should include public holidays.

"If you want to know how shoe fits, ask the person who is wearing it, not the one who made it". Planners or planning authority should not always think they are providing the best for the public without effective public participation in the planning process. 


\section{REFERENCES:}

\section{Books:}

Conor, Desmond M. 1997. Constructive Citizen Participation: How to Prevent and Resolve Public Controversy. Connor Development Services Ltd: Canada.

Conor, Desmond M. 1999. Model Approaches for Public Participation. Connor Development Services Ltd: Canada.

Hunt D. and Johnson C. 1995. Environmental Management Systems - Principle and Practice. McGraw Hill Book Company: London.

Jones K. and Scholz A. 2003. "World Summit to the Movement - Do You Have a Pulse?"in Earth Island Journal. EBSCO Publishing.

Karel van der Zwiep. 1994. "Public Participation as an Instrument for Environmental Protection" in Manual on Public Participation in Environmental Decision Making. Regional Environmental Center for Central and Eastern Europe.

Laws of Malaysia. Federal Territory (Planning) Act 1982 - Act 267.

Laws of Malaysia. 2002. Town and Country Planning Act 1976 (Act 172). International Law Book Services: Kuala Lumpur.

Nagy M. T. et al. 1994. Manual on Public Participation in Environmental Decision Making. Regional Environmental Center for Central and Eastern Europe: Europe.

Ortolano L. 1984. Environmental Planning and Decision Making. Stanford University: Canada.

The Co-Intelligence Institute. 2002. Principles of Public Participation.

\section{Internet:}

Agenda 21 and the 1992 Earth Summit Agreements. http://habitat.igc.org.

Fundacion Ambientey Recursos Naturales. 2001. Access to Decision-Making Processes. www.farn.org.ar/docs/pp/en procesos.html.

Fundacion Ambientey Recursos Naturales. 2001. Access to Public Information. www.farn.org.ar/docs/pp/en information1.html.

United Nations Division for Sustainable Development. 2002. United Nations: Sustainable Development. http://www.un.org.

U. S. Environmental Protection Agency. 2002. RCRA Public Participation Manual. www.epa.gov/epaoswer/hazwaste/permit/pubpart/manual.htm. 


\section{APPENDIX:}

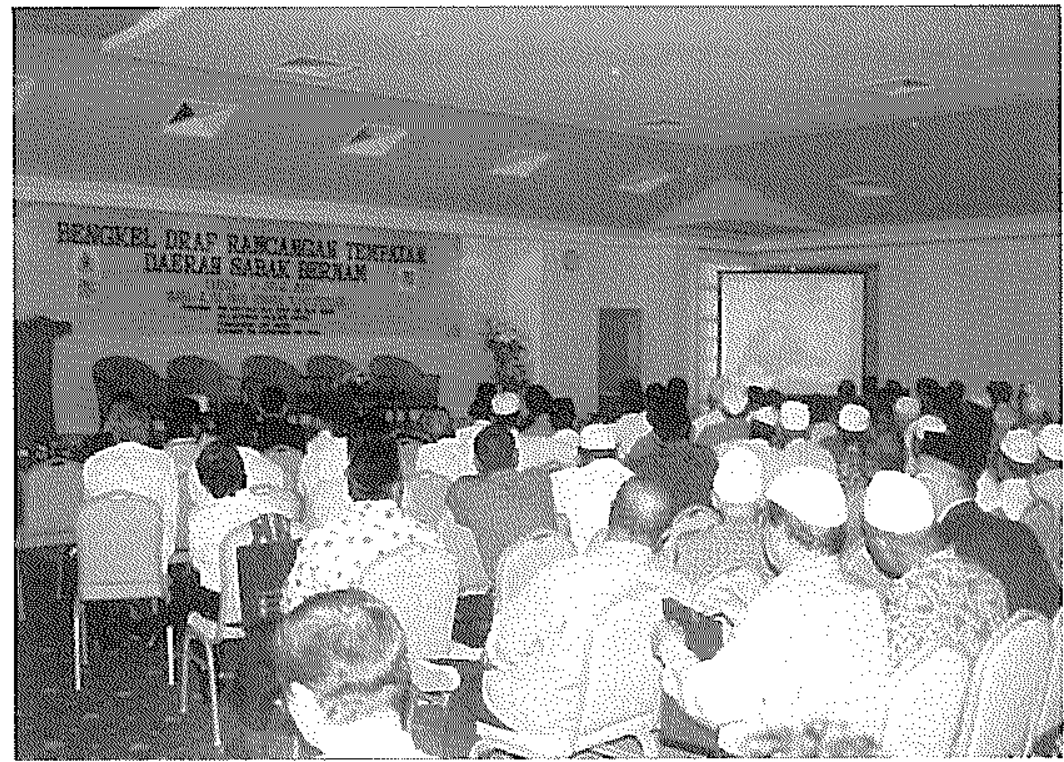

Photo A: Workshop for Draft Sabak Bernam District Local Plan (SBDLP) held on 10 July, 2003.

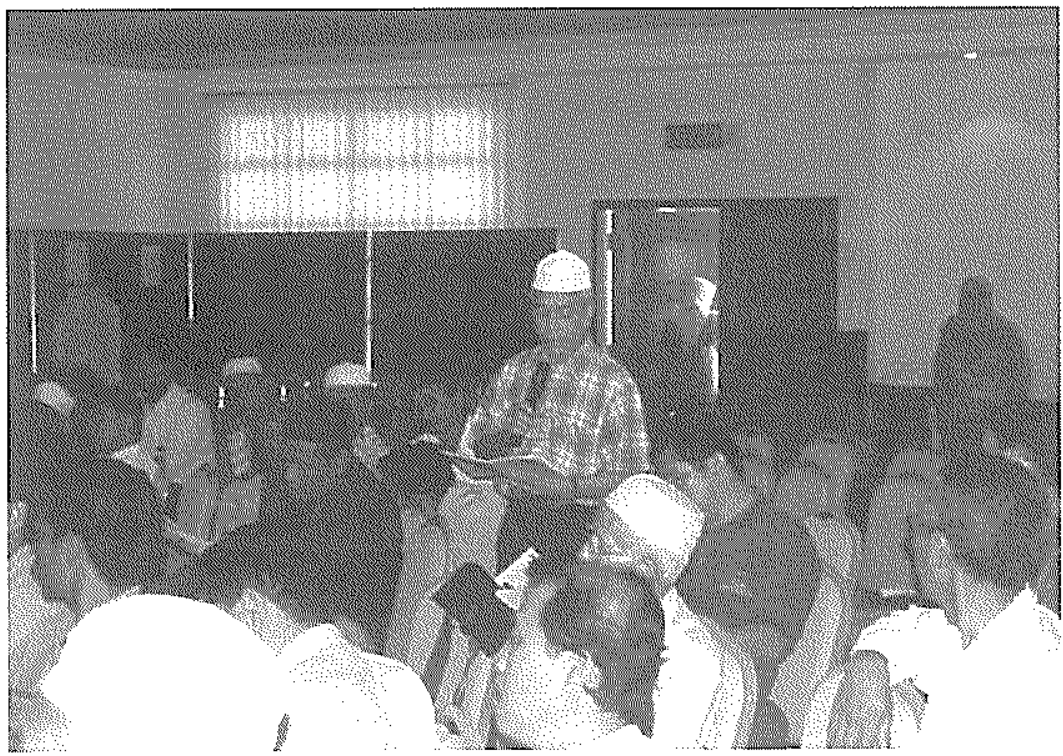

Photo B: Participants are giving their opinions, comments and views in the SBDLP workshop. 


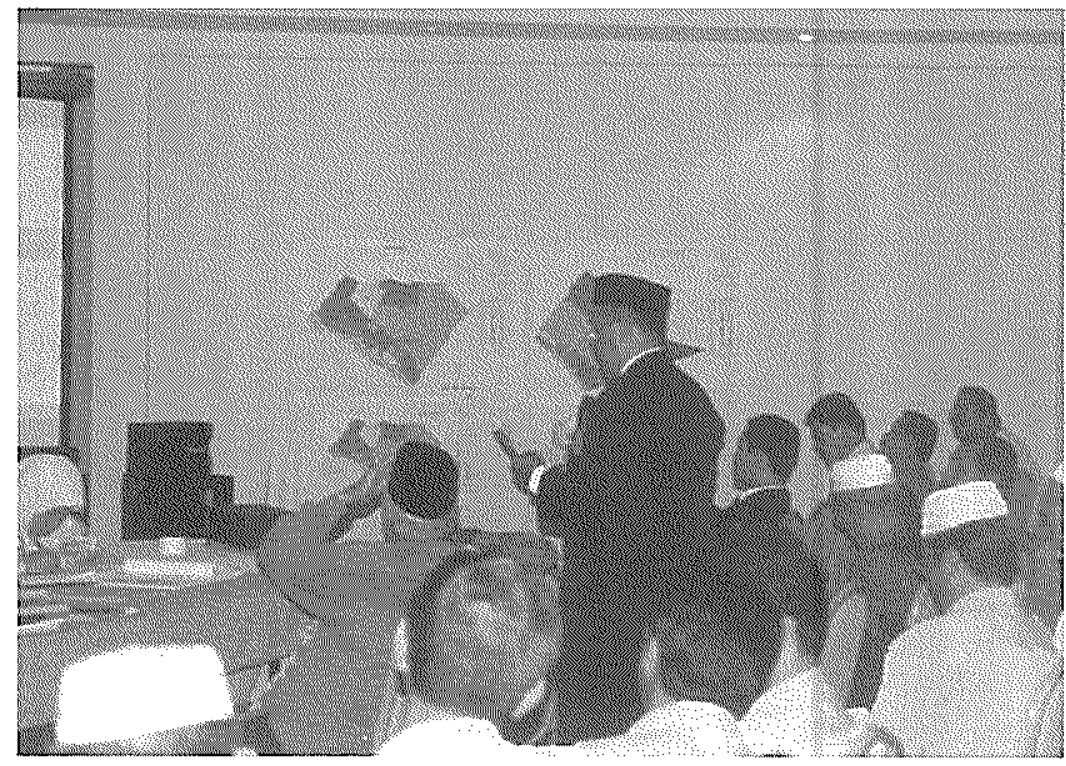

Photo C: Participants are giving their opinions, comments and views in the SBDLP workshop.

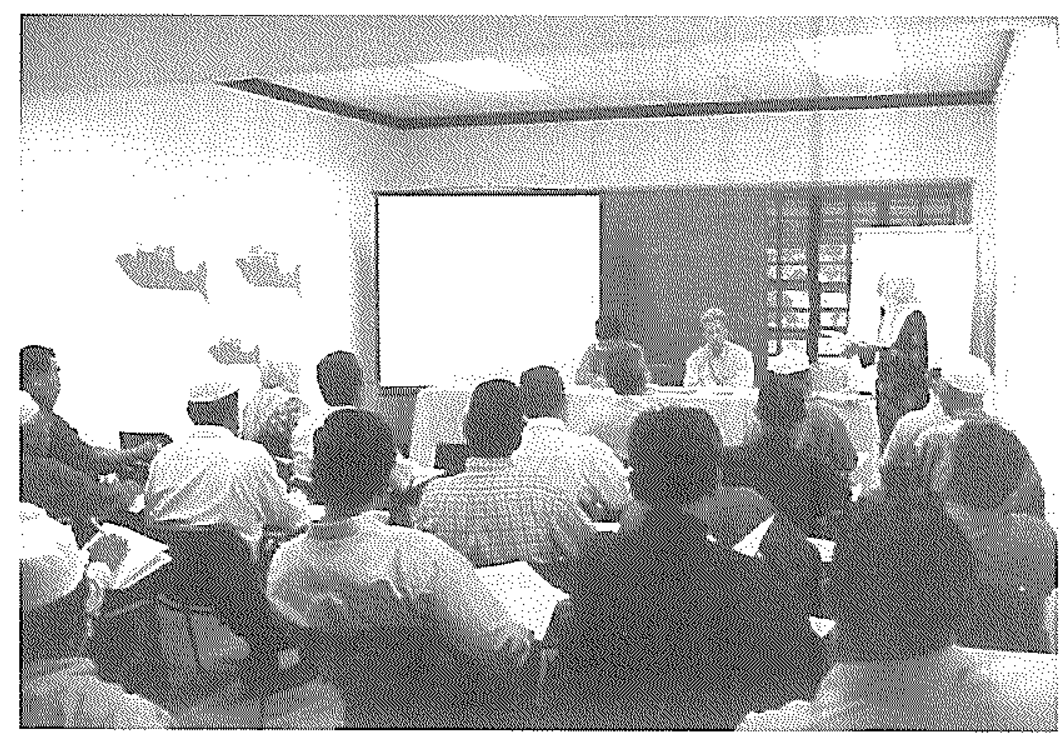

Photo D: Small group discussion in one of the sessions during the workshop (SBDLP). 


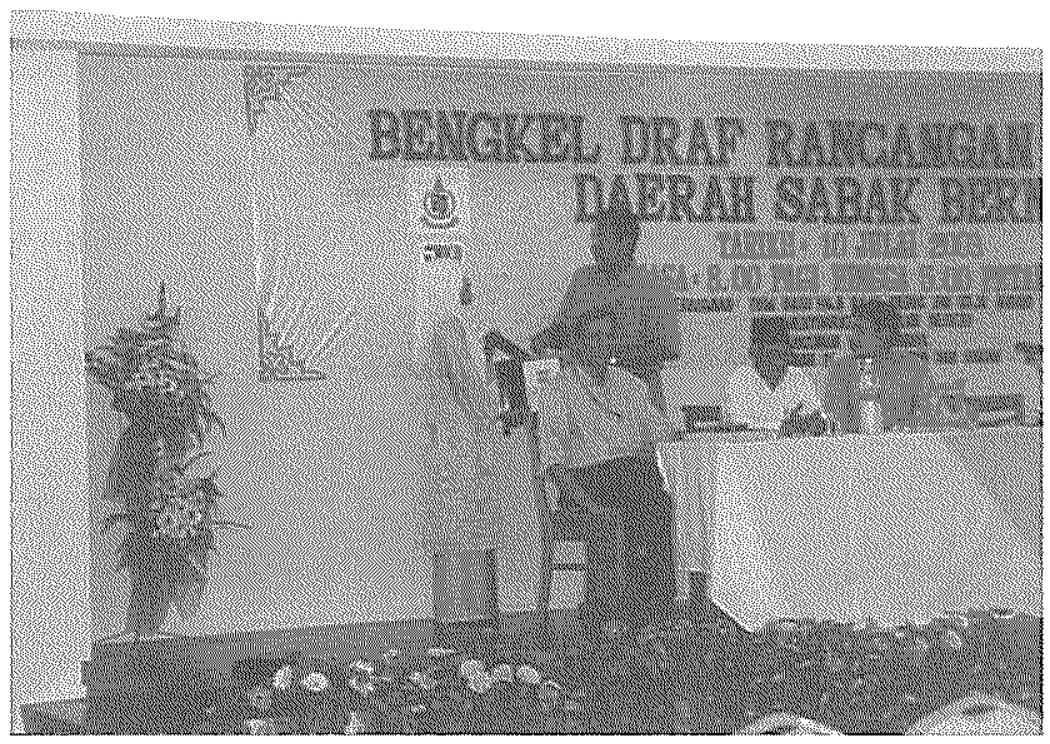

Photo E: 'Lucky draw' event to attract public to participate in the workshop (SBDLP).

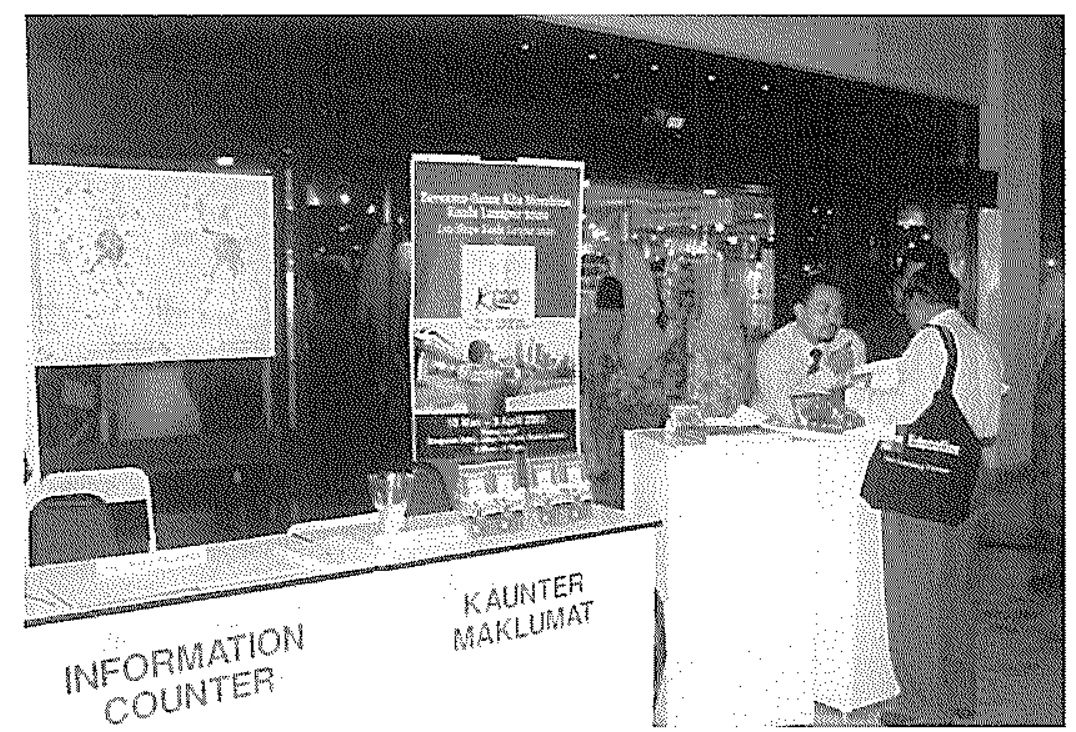

Photo F: Information counter and counter for selling draft KLSP report. 


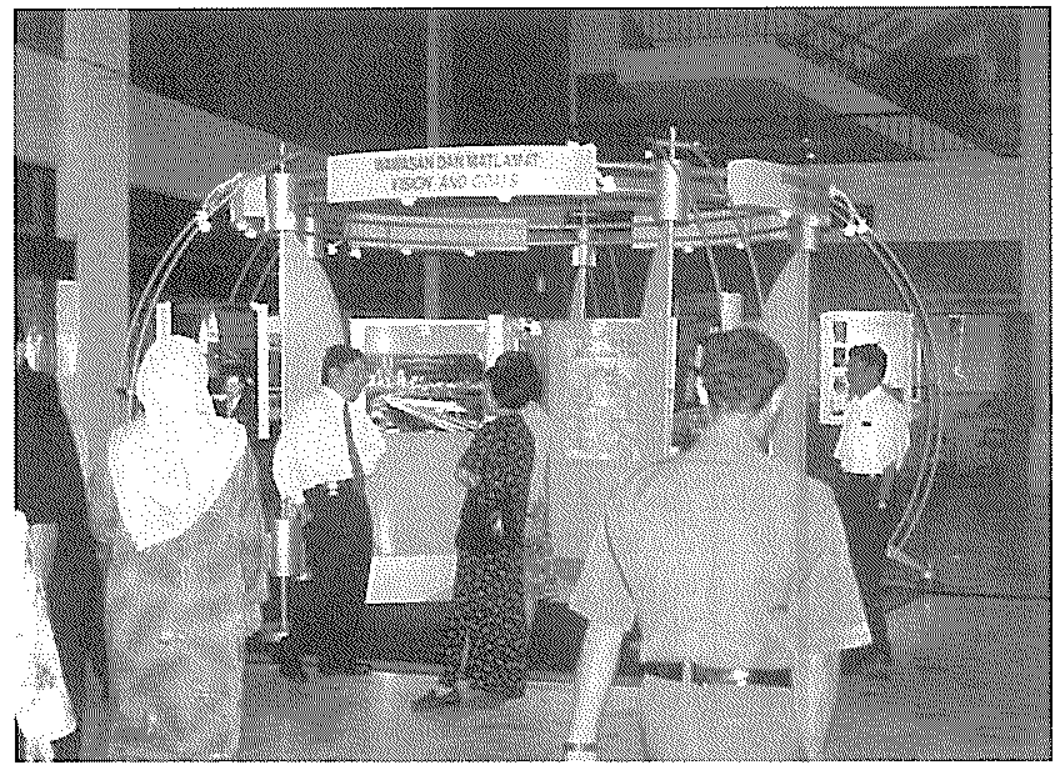

Photo G: Public exhibition of Draft Kuala Lumpur Structure Plan.

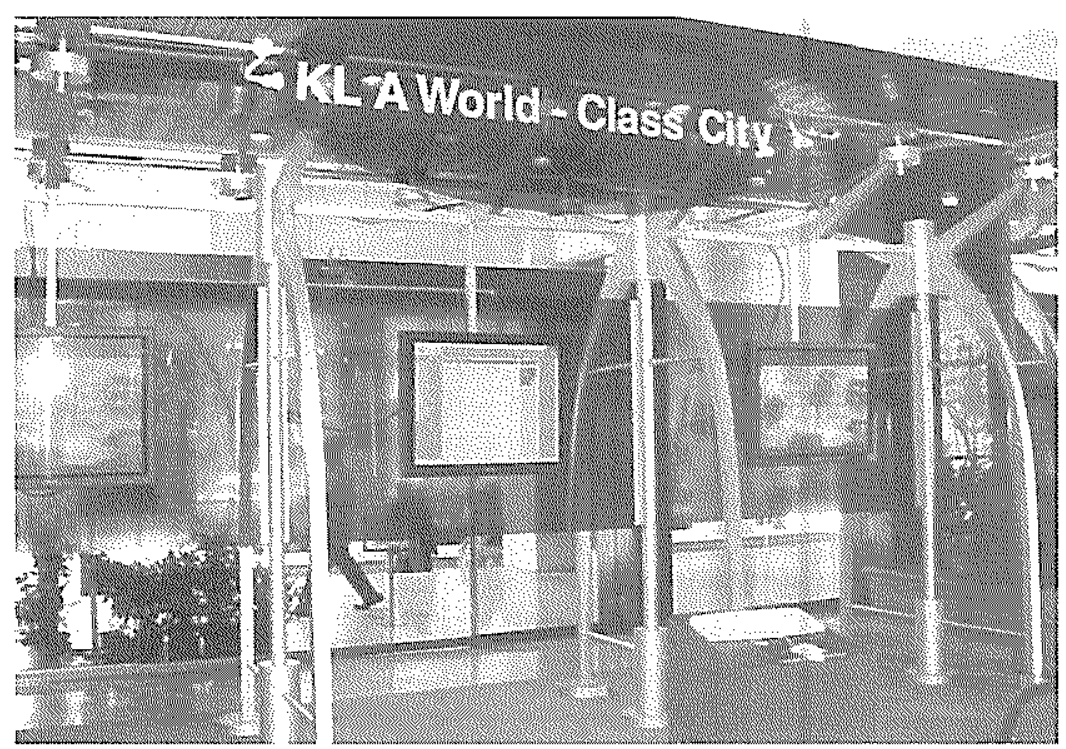

Photo H: The use of multimedia in the Draft Kuala Lumpur Structure Plan exhibition. 


\author{
PLANNING MALAYSIA \\ Journal of the Malaysian Institute of Planners (2007) V, $17-42$
}

\title{
MULTICRITERIA ANALYSIS OF FLOOD CAUSES IN KUALA LUMPUR
}

\author{
Nur Fazzillah Muhamed Noordin ${ }^{1}$ \\ Project Executive, \\ GEOINFO SERVICES SDN BHD \\ Alias Abdullah ${ }^{2}$ \& Muhammad Nur Azraei Shahbudin ${ }^{3}$ \\ INTERNATIONAL ISLAMIC UNIVERSITY MALAYSIA
}

\begin{abstract}
In today's world, natural disasters are becoming frequent occurrence as a result of human's excess and waste in using resources, especially land. Its effects can be seen in disasters such as flood in urban areas where population and built-up area is dense. Many studies have been conducted in flood prediction and river management but very few concentrate on evaluation of flood occurrence factors at rivers in urban areas. This study evaluates the significance of factors that cause urban flash floods in Kuala Lumpur by using Multi-Criteria Analysis (MCA) method with special reference to DEFINITE software. This study carries out a systematic approach encompassing a selection of criteria that determines the root cause of flood through consultation with major stakeholders like Department of Irrigation and Drainage (DID), Department of Environment (DOE), Kuala Lumpur City Hall (DBKL), and Malaysian Meteorological Department (MMD). Less than obvious results are due to the complexity and reality of the problem based on the interview of stakeholders with different views on the local environment. The MCA results reveal that stream and land (land use) are the main causes of flooding in urban areas that can be solved with a proper physical planning.
\end{abstract}

Keywords: MCDA, Flood Disasters, Risk Management, Urbanisation, Environment

\footnotetext{
${ }^{1}$ She received a Bachelor Degree of Urban and Regional Planning from International Islamic University Malaysia (fazzillah@geoinfo.com.my).

${ }^{2}$ Professor, Department of Urban and Regional Planning, Kulliyyah of Architecture and Environmental Design, International Islamic University Malaysia, Kuala Lumpur (dralias@iiu.edu.my).

${ }^{3}$ Research Officer, IIUM Consultancies, International Islamic University Malaysia, Kuala Lumpur (azraeishahbudin@gmail.com).
} 


\section{INTRODUCTION}

In 1998 Yangtze's worst flood in 44 years occurred due to deforestation and intensive land development (Brown and Halweil, 1998) whilst in 2004, Bangladesh 10-year cycle floods arrived early also due to deforestation and irrigation (Logan, 2004). However, the 1995 flood in the Netherlands was due to melt water from mountains and extremely heavy rainfall ${ }^{4}$ and the 2002 flood

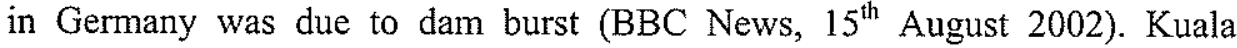
Lumpur is similar to China and Bangladesh where floods were due to human hand, in contrast with the Netherlands and Germany where floods were natural disasters.

Understanding the flood problem begins by finding out its root cause. The root cause is uncovered through the systematic approach of evaluating the causes of flood in urban areas such as Kuala Lumpur. A systematic approach would encompass a selection of criteria that can determine which, from a range of factors, are the root causes of flood. By establishing the root causes of flood measures can be taken to solve the flood problem from a specific scope of recommendations.

Working out the factors that cause floods is important although arguably there could be conflicting results. This is due to the complexity and reality of the problem and is based on the evaluation of authorities with different expertise and specialisations. The complexity of the problem could prevent any definite measure to be recommended for flood mitigation. However, short-term and long-term initiatives are recommended.

This study evaluates the significance of factors that cause urban flash floods at the Sg. ${ }^{5}$ Gombak catchment area within Kuala Lumpur by using the MultiCriteria Analysis (also called the Multiple Criteria Decision Analysis (MCDA)) method. The application of MCA in this study has shown its effectiveness in assisting urban planners, authorities, decision makers, stakeholders and the public or end users as stated in Spatial Planning And Decision Support System For Modelling Water Resources (Alias Abdullah et al., 2004), and Evaluating Rail Network Options Using MCDA (Ali Sharifi et al., 2004). It is aimed to assist parties who have an interest in urban flooding to take measures that will mitigate the hazards in the study area through long-term and short-term initiatives

\footnotetext{
${ }^{4}$ Ministerie van Buitelandse Zaker, 2005

${ }^{5}$ Sg. represents sungai or river. E.g., Sg. Gombak means Gombak River.
} 


\section{The Problem}

The Klang Valley (comprising of Kuala Lumpur and five other districts in Selangor State) has grown to encompass a wide expanse of highly urbanised area since 1860 as people from the rural areas had begun to migrate to the towns in hopes of a better life. Lack of proper planning back then forced many to set up squatter colonies. The advent of urbanisation saw Kuala Lumpur face many problems both social and physical in nature. The ad-hoc town gave way to a rapidly developing but unplanned city that grew dangerously close to the rivers. In the past, the occurrence of these floods is notably more often and more vicious. According to Salmah (2004), the problem of increased occurrences of flash floods in the Klang Valley is a consequence of unplanned development in the flood plains, resulting in changes to the environment.

There are two main rivers in Kuala Lumpur that are most prone to flooding due to their close proximity to urban areas, specifically Sg. Gombak and Sg. Klang. There is much evidence of public and drainage works being done to control the flooding of Sg. Klang such as the Stormwater Management and Road Tunnel $\left(\right.$ SMART) ${ }^{6}$, a two-pronged project under the Federal Government to alleviate the flood problem and ease traffic congestion in Kuala Lumpur city centre. On the other hand, there has been no news as yet of flood control measures intended for Sg. Gombak. Thus, Sg. Gombak catchment area within Kuala Lumpur is the case for this study and a reference for the MCA evaluation (see Figure 1).

There can be many causes of flood in Sg. Gombak due to the natural phenomena. However, the main factors that cause floods in urban areas like Kuala Lumpur mostly stem from human activities.

The first factor is land use change (here we called it as land factor). For the past fifty years the morphology of Kuala Lumpur had significantly changed from a known mining town to a modern capital city. The rapid urbanisation process had made Kuala Lumpur a modern concrete jungle. Empirical studies by scholars from various universities and research institutes had showed that floods in Kuala Lumpur and Klang Valley were due to impervious land or ground surfaces that cannot absorb water into the soil effectively thus causing flood at areas closest to the rivers.

\footnotetext{
${ }^{6}$ SMART is an acronym for Stormwater Management and Road Tunnel, a project under the Federal Government of Malaysia initiated to alleviate the flooding problem in the city centre of Kuala Lumpur. See http://www.smarttunnel.com.my/home.htm on the project.
} 


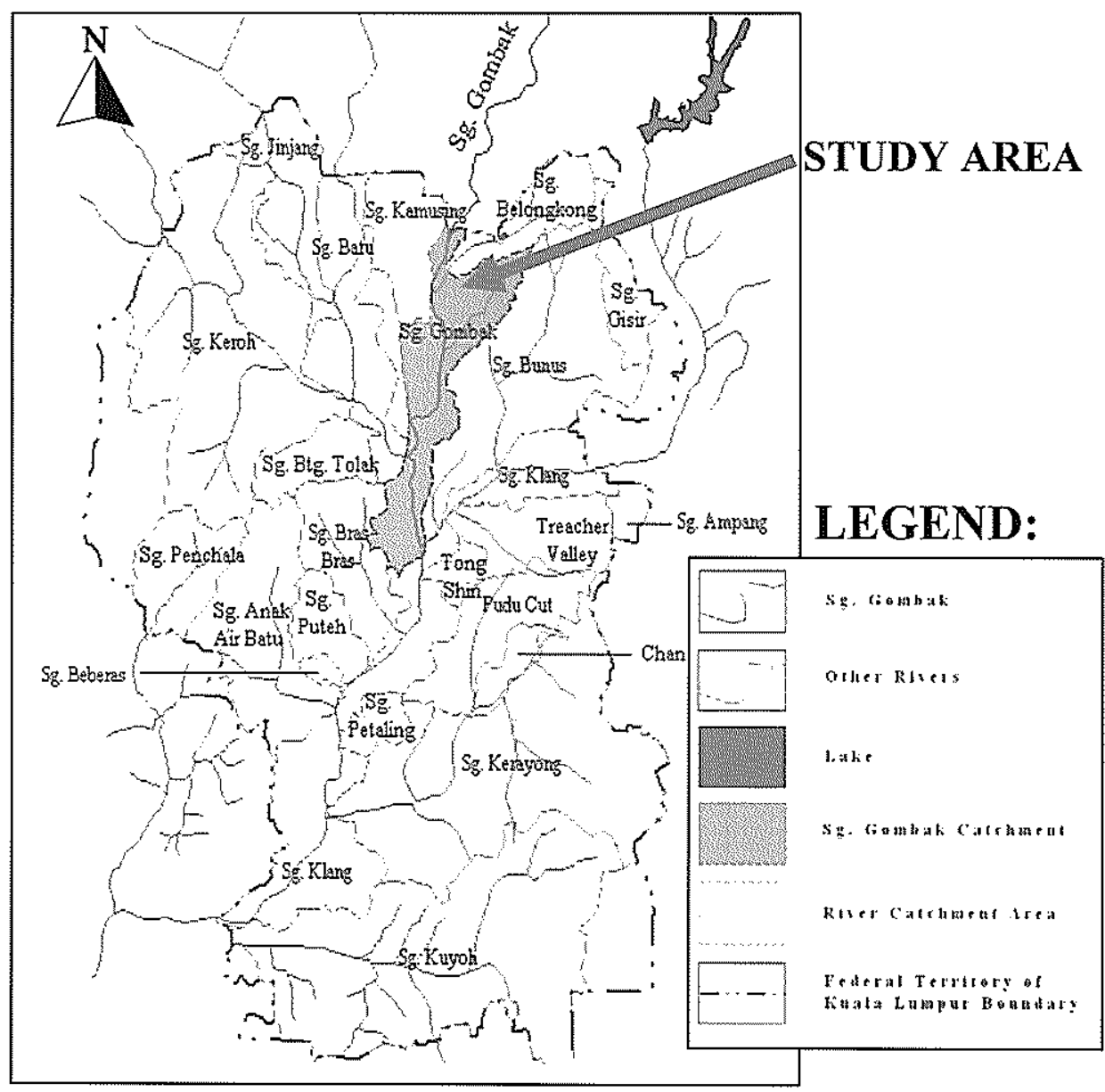

Figure 1: The Study Area of Sg. Gombak, Kuala Lumpur

The second factor is Sg. Gombak does not have the capacity to drain off water quickly during heavy rain. In the ' $90 \mathrm{~s}$, it was cited that the cause for flooding in the Kuala Lumpur city centre was due to clogging of drains and its capacity to hold very low volume of water.

The third factor is heavy rain as the cause of flooding. Floods occur more often during the monsoon season as the monsoon storms rain heavily on the west coast of Peninsular Malaysia. Other weather factors that contribute to flooding are such as the global La Nina effect. As the monsoon storms follow a set pattern each year, there should be increased ability to manage the weather 
effects. Even so, more often than not urban flooding also occurs after only a light evening shower.

\section{OBJECTIVE}

The main objective is to find out systematically the most significant urban flood factor of highest priority in Sg. Gombak catchment area within Kuala Lumpur. The systematic evaluation uses MCA, which includes weight assignation of a selection of criteria by authorities and pairwise comparison of the objectives of each authority. Four government departments namely DID (Department of Irrigation and Drainage), DOE (Department of Environment), DBKL (Kuala Lumpur City Hall) and MMD (Malaysian MeteorologicaL Department), are chosen for the interview due to their relevance to the study area and scope of work.

\section{RIVER HYDROLOGY AND THE CHARACTERISTICS OF URBAN FLOODS}

Urban flood characteristics are different from rural floods. Firstly there must be a definition of what is known as 'urban area' and secondly what is the definition of 'flood'. From then on, the collective term of 'urban flood' can be better understood in terms of physical area where it occurs, its causes or factors, and its basic dynamics. Through the understanding of urban floods, criteria (including its respective indicator) for urban flood improvement are then derived and selected for the weight assignation and evaluation exercise.

\section{URBAN FLOOD OCCURRENCE FACTORS}

The factors are generally reasons that cause and intensify flood events in urban areas. Smith (1998) summarises the factors of flood occurrence - rain, basin (stable and variable), and channel factors (refer Figure 2). 


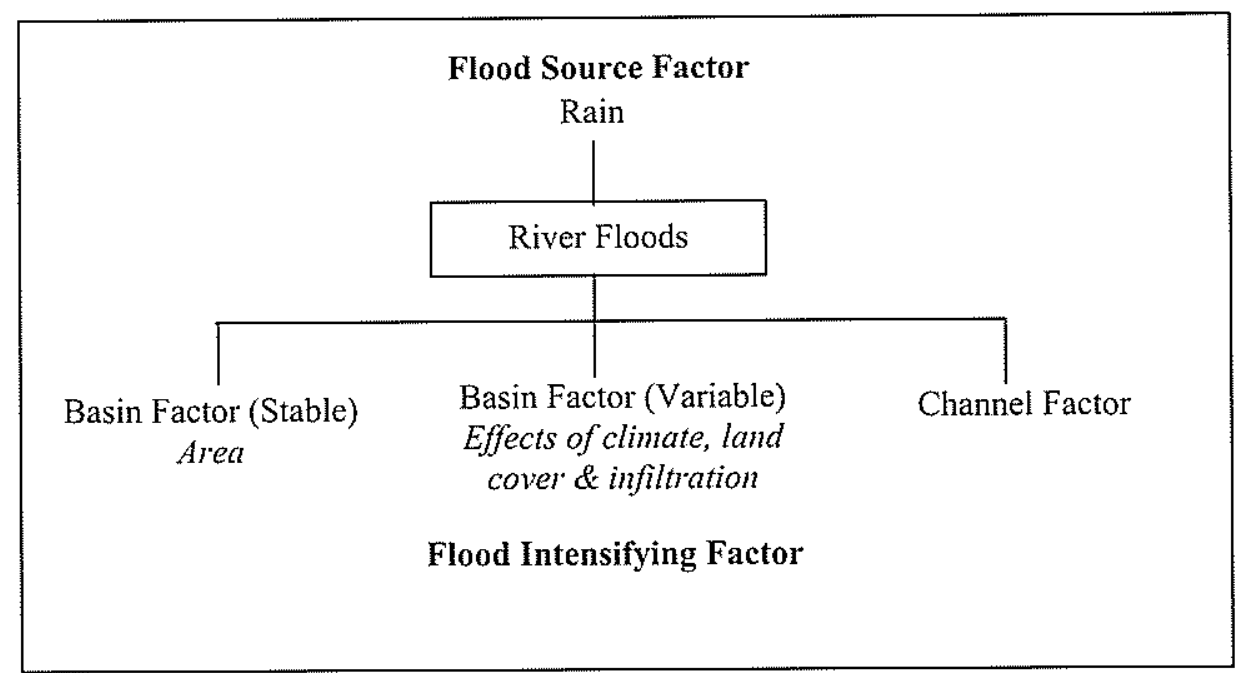

Figure 2: Flood cause factor and flood intensifying factors (After Smith, 1998)

\section{FLOOD MITIGATION AUTHORITIES RELATED TO SG. GOMBAK CATCHMENT AREA}

Understanding the organisation of authorities in charge of flood mitigation is imperative so that the choice of authorities to be interviewed will focus on the problem at hand. Only four authorities are selected for the interview so that their overall opinions will give an overview to the flood problem in Sg. Gombak. The first would be the authority responsible for planning and development of land within Sg. Gombak catchment area (i.e. DBKL), and the second is the authority responsible for the Sg. Gombak watercourse (i.e. DID). The third would be the authority responsible for the environment as a whole (i.e. DOE) and the fourth is the authority that can forecast the flood-causing weather (i.e. MMD).

\section{MCA EVALUATION AND FINDINGS}

The multiple criteria evaluation (MCE) of the flood factors is carried out based on the performances of each factor on various defined criteria and the relative importance of each criterion. The objective data is derived through assessment of the land use and environmental impacts of each flood factor interviews and processed using MCDA. In observing the performance of each flood factor on a different criterion shows that there is one option that dominates the others. This 
is expected although the flood factors are comparable to each other due to the nature of the problem. The result of this process is given in the "effects table".

The subjective information relates to the relative importance of objectives and criteria valued in interviews using the pairwise comparison method. In this process, the authorities made judgements on the relative importance of three main objectives in obtaining the flood factor i.e. physical planning, engineering and environmental objectives. Physical planning is important because the study area is located in a highly built-up area and therefore planning is essential, whereas engineering objective is included for the stream aspect, and lastly, environmental objective is to present the ecological aspect of the problem. The authorities interviewed include DID, DBKL, DOE, and MMD.

\section{A structured pairwise comparison as the assessment procedure}

Structured pairwise comparison is a priority assessment procedure, a judgement on the relative importance of the three main objectives outlined, namely physical planning, engineering and environmental aspects. Using the pairwise comparison method, the representatives of authorities made an assessment on the priorities of objectives. For this process the following procedure was used.

The main objectives were presented in a table such as Table 1 . Then, each representative was asked to rank the importance or relevance of the main objectives of the flood factors as seen by each authority. Table 1 depicts the outcome of the survey of various authorities.

The representatives then rank the order of importance between each of the objectives. Using the information in Table 1 for a structured pairwise comparison technique, the relative importance of the objectives and criteria for each authority was derived. Table 2 presents the relative importance of the main objectives as derived from Table 1.

Based on Table 1 that presents the relative importance of the main objectives as perceived by each authority, three out of four authorities stated identical relative importance of the main objectives. In the survey, all the authorities feel that the physical planning objective is relatively strongly more important than the other objectives when it comes to evaluating flood occurrence factors. However, in the opinion of $\mathrm{MMD}$, the environmental objective is less important as the natural environment can be controlled or predicted only to a certain extent such as rainfall, wind flow, weather pattern, etc. 
Table 1: Summary of relative importance of the main objectives as perceived by each authority

\begin{tabular}{|c|c|c|c|c|c|}
\hline & $\begin{array}{l}\text { Weakly } \\
\text { more } \\
\text { important }\end{array}$ & $\begin{array}{l}\text { Strongly } \\
\text { more } \\
\text { important }\end{array}$ & & $\begin{array}{c}\text { Weakly } \\
\text { more } \\
\text { important }\end{array}$ & $\begin{array}{l}\text { Strongly } \\
\text { more } \\
\text { important }\end{array}$ \\
\hline DID & & & DOE & & \\
\hline $\begin{array}{l}\text { Physical } \\
\text { Planning }\end{array}$ & & $\mathrm{X}$ & $\begin{array}{l}\text { Physical } \\
\text { Planning }\end{array}$ & & $\mathrm{X}$ \\
\hline Engineering & $X$ & & Engineering & & $\mathrm{X}$ \\
\hline Environment & $\mathrm{X}$ & & Environment & $X$ & \\
\hline DBKL & & & MMD & & \\
\hline $\begin{array}{l}\text { Physical } \\
\text { Planning }\end{array}$ & & $\mathrm{X}$ & $\begin{array}{l}\text { Physical } \\
\text { Planning }\end{array}$ & & $\mathrm{X}$ \\
\hline Engineering & $\mathrm{X}$ & & Engineering & $\mathrm{X}$ & \\
\hline Environment & $\mathrm{X}$ & & Environment & $\mathrm{X}$ & \\
\hline
\end{tabular}

According to DID, the physical planning is most important especially in the integration of drainage to the urban layout for channeling runoff and floodwaters especially from critical points. DBKL also agrees in this respect, not only with the view that proper physical planning can help mitigate flooding near the city centre but also on enforcement of garbage dumping into the river. In the opinion of $\mathrm{DOE}$, the engineering objective also has strong importance in this study because the engineering aspect of the river plays a significant role in controlling and mitigating flood; such as those that contribute to smooth flow of water including shape of streambed and its material, sedimentation rate, etc.

Table 2 shows the detailed results of the structured pairwise comparison method that was calculated. The authority that assigned the highest weight to physical planning objective is DBKL. With Kuala Lumpur geared towards excellent standards (world-class), the physical aspect is most important. This view is also somewhat shared by DID. 
Table 2: Structured pairwise comparison method

(weights translation as perceived by each authority)

\begin{tabular}{|l|c|c|}
\hline \multicolumn{1}{|c|}{ DID } & Weight & (\%) \\
\hline Physical Planning & 0.694 & 69.4 \\
\hline Engineering & 0.128 & 12.8 \\
\hline Environment & 0.178 & 17.8 \\
\hline \multicolumn{1}{|c|}{ DOE } & & \\
\hline Physical Planning & 0.439 & 43.9 \\
\hline Engineering & 0.323 & 32.3 \\
\hline Environment & 0.238 & 23.8 \\
\hline \multicolumn{1}{|c|}{ DBKL } & & \\
\hline & & 70.4 \\
\hline Physical Planning & 0.704 & 15.4 \\
\hline Engineering & 0.154 & 14.2 \\
\hline Environment & 0.142 & \\
\hline & & 58.2 \\
\hline MMD & 0.582 & 25.8 \\
\hline Physical Planning & 0.258 & 16.0 \\
\hline Engineering & 0.160 & \\
\hline Environment & & \\
\hline
\end{tabular}

The physical planning objective is important as stated by DID for practical aspects. In the survey of the authority representatives' opinion, much of their work involves laying down drainage at the most appropriate location besides monitoring and maintaining it. This calls for a lot of time spent on planning, research, and cost, therefore making the physical planning objective their concern in order not to waste valuable time, manpower and money. Like DBKL, engineering and environmental objectives are lesser concerns in terms of flooding although it was stressed that DID pays equal attention to all objectives. This is due to engineering being a means to mitigate flood before it happens i.e. river and drainage construction, whereas environment is beyond their scope of work. 
With both DOE and MMD, although the weight is definitely more on physical planning, it appears as if both authorities' representatives balance their views to encompass the bigger picture. The weights assigned to all three objectives are more evenly spread although not to the point of being equal. There being no doubt that physical planning is the objective with the highest weight in all four authorities, the second highest weight on engineering and lowest weight on environmental objectives was also assigned by all except for DID.

\section{Evaluation objectives, criteria and indicators}

With the authorities' rank of objective importance known, evaluation of the flood factors commences with the basic outline of objectives, criteria and indicators of the study. The table summarising this is reproduced and rearranged with the inclusion of the MCDA objectives as shown in Table 3 . Figure 3 illustrates the structure of MCA evaluation.

Table 3: Objectives, criteria and indicators in evaluating urban flood occurrence

\begin{tabular}{|l|l|l|}
\hline \multicolumn{1}{|c|}{ MAIN } & \multicolumn{1}{|c|}{ CRITERIA } & \multicolumn{1}{c|}{ INDICATOR } \\
\hline \multirow{5}{*}{$\begin{array}{l}\text { PHYSICAL } \\
\text { PLANNING }\end{array}$} & $\begin{array}{l}\text { a. Maximise natural } \\
\text { absorption } \\
\text { mechanism }\end{array}$ & $\begin{array}{l}\text { Natural ground cover } \\
\text { designated for each flood } \\
\text { factor to prevent flood }\end{array}$ \\
\cline { 2 - 4 } & $\begin{array}{l}\text { b. Minimise built-up } \\
\text { density in the urban } \\
\text { area }\end{array}$ & $\begin{array}{l}\text { Developed area within } \\
\text { catchment that delays water } \\
\text { flow into ground or stream }\end{array}$ \\
\cline { 2 - 4 } & $\begin{array}{l}\text { c. Maximise strategic } \\
\text { initiatives in } \\
\text { managing river and } \\
\text { flood issue }\end{array}$ & $\begin{array}{l}\text { Strategic plans implemented } \\
\text { within the last 5 years for } \\
\text { floods }\end{array}$ \\
\hline \multirow{5}{*}{$\begin{array}{l}\text { ENGINEERING } \\
\text { OBJECTIVES }\end{array}$} & $\begin{array}{l}\text { d. Maximise specific } \\
\text { and scientific data on } \\
\text { frequency and } \\
\text { magnitude of flooding }\end{array}$ & $\begin{array}{l}\text { Number of floods in 2003- } \\
\text { 2004 caused by each factor }\end{array}$ \\
\cline { 2 - 4 } & $\begin{array}{l}\text { e. Maximise utilisation } \\
\text { of flood warning } \\
\text { system }\end{array}$ & $\begin{array}{l}\text { Usage of flood warning } \\
\text { board / siren }\end{array}$ \\
\hline
\end{tabular}




\begin{tabular}{|c|c|c|}
\hline $\begin{array}{c}\text { MAIN } \\
\text { OBJECTIVES }\end{array}$ & CRITERIA & INDICATOR \\
\hline \multirow[b]{3}{*}{$\begin{array}{l}\text { ENVIRONMENTAL } \\
\text { OBJECTIVES }\end{array}$} & $\begin{array}{l}\text { f. Maximise river } \\
\text { conservation } \\
\text { (naturalness of the } \\
\text { river) }\end{array}$ & $\begin{array}{l}\text { Percent length of river with } \\
\text { natural bank }\end{array}$ \\
\hline & $\begin{array}{l}\text { g. Minimise river } \\
\text { modifications }\end{array}$ & $\begin{array}{l}\text { Percent length of river with } \\
\text { modified bank }\end{array}$ \\
\hline & $\begin{array}{l}\text { h. Maximise experts' } \\
\text { knowledge to study } \\
\text { on urban flood } \\
\text { problems (including } \\
\text { decision makers, } \\
\text { stakeholders, } \\
\text { engineers and } \\
\text { planners) }\end{array}$ & $\begin{array}{l}\text { No. of studies conducted on } \\
\text { flood }\end{array}$ \\
\hline
\end{tabular}

The three main objectives of this study are underpinned by certain criteria. The criteria are to achieve the objectives of the study through indicators. Next, with the criteria and indicators on hand, the "effects table" is developed specifically for this study, the element on which multi-criteria evaluation ${ }^{7}$ is based upon. It consists of rows of indicators outlined previously (also known as "effects" in this exercise), and columns of urban flood factors. The urban flood factors in this study are three; namely land (as in relation to urbanisation), stream (as in relation to drainage) and rain (as in relation to weather). In the boxes where indicators and flood factors correspond, the performances of the indicators are assigned in appropriate units.

This data input into the effects table was done by the four representatives of the authorities; namely DID, DOE, DBKL and MMD. Looking at the main objectives, physical planning aspect is reflected in DBKL as one of the authorities, engineering aspect is reflected in DID and partly the DOE, and the environment aspect is reflected in DOE and MMD. All the interviewees are from the public sector because a greater number of people are affected by the decisions that are made in comparison with other sectors such as NGOs and private sector. The method of data input is through interview and telephone

\footnotetext{
${ }^{7}$ DEFINITE2.0 software (2000) was developed by the Institute for Environmental Studies, Vrije University, Amsterdam, The Netherlands.
} 
interview. In some cases, one officer did not have all the data required; therefore the survey is continued with other officers within the department.

Table 5 shows the effects table as filled in by representatives of the Department of Irrigation and Drainage (DID). According to DID, the data in this effects table is estimation and is not conclusive.

Table 5: Effects table showing performance of each flood occurrence factor - DID, Kuala Lumpur

\begin{tabular}{|c|c|c|c|c|}
\hline Department of Irrigation and & Unit & Land & Stream & Rain \\
\hline \multicolumn{5}{|l|}{ PHYSICAL PLANNING OBJECTIVES } \\
\hline \multicolumn{5}{|c|}{ a. Maximise natural absorption mechanism } \\
\hline $\begin{array}{l}\text { Natural ground cover designated } \\
\text { to prevent flood (for each flood } \\
\text { factor) }\end{array}$ & $\%$ & 12 & 15 & 0 \\
\hline \multicolumn{5}{|c|}{ b. Minimise built-up density in the urban area } \\
\hline $\begin{array}{l}\text { Developed area within catchment } \\
\text { that delays water flow into } \\
\text { ground or stream }\end{array}$ & $\%$ & 80 & 15 & 5 \\
\hline \multicolumn{5}{|c|}{ c. Maximise strategic initiatives in managing river and flood issue } \\
\hline $\begin{array}{l}\text { Strategic plans implemented } \\
\text { within the last } 5 \text { years (for flood } \\
\text { mitigation) }\end{array}$ & $\begin{array}{l}\text { No. of } \\
\text { strategies }\end{array}$ & 2 & 1 & 0 \\
\hline \multicolumn{5}{|l|}{ ENGINEERING OBJECTIVES } \\
\hline \multicolumn{5}{|c|}{$\begin{array}{l}\text { d. Maximise specific and scientific data on frequency and magnitude of } \\
\text { flooding }\end{array}$} \\
\hline $\begin{array}{l}\text { Number of floods in 2003-2004 } \\
\text { caused by each factor }\end{array}$ & $\begin{array}{l}\text { No. of } \\
\text { events }\end{array}$ & 0 & 0 & 5 \\
\hline \multicolumn{5}{|c|}{ e. Maximise utilisation of flood warning system } \\
\hline $\begin{array}{l}\text { Usage of flood warning board / } \\
\text { siren in } 2003-2004\end{array}$ & $\begin{array}{l}\text { No. of } \\
\text { times }\end{array}$ & 3 & 3 & 0 \\
\hline \multicolumn{5}{|l|}{ ENVIRONMENTAL OBJECTIVES } \\
\hline \multicolumn{5}{|c|}{ f. Maximise river conservation (naturalness of the river) } \\
\hline $\begin{array}{l}\text { Percent length of river with } \\
\text { natural bank }\end{array}$ & $\%$ & 30 & 5 & 0 \\
\hline \multicolumn{5}{|l|}{ g. Minimise river modifications } \\
\hline $\begin{array}{l}\text { Percent length of river with } \\
\text { modified bank }\end{array}$ & $\%$ & 70 & 95 & 0 \\
\hline \multicolumn{5}{|c|}{$\begin{array}{l}\text { h. Maximise experts' knowledge to study on urban flood problems (including } \\
\text { decision makers, stakeholders, engineers and planners) }\end{array}$} \\
\hline $\begin{array}{l}\text { No. of studies conducted on flood } \\
\text { in the last } 5 \text { years }\end{array}$ & $\begin{array}{l}\text { No. of } \\
\text { studies }\end{array}$ & 0 & 0 & 0 \\
\hline
\end{tabular}




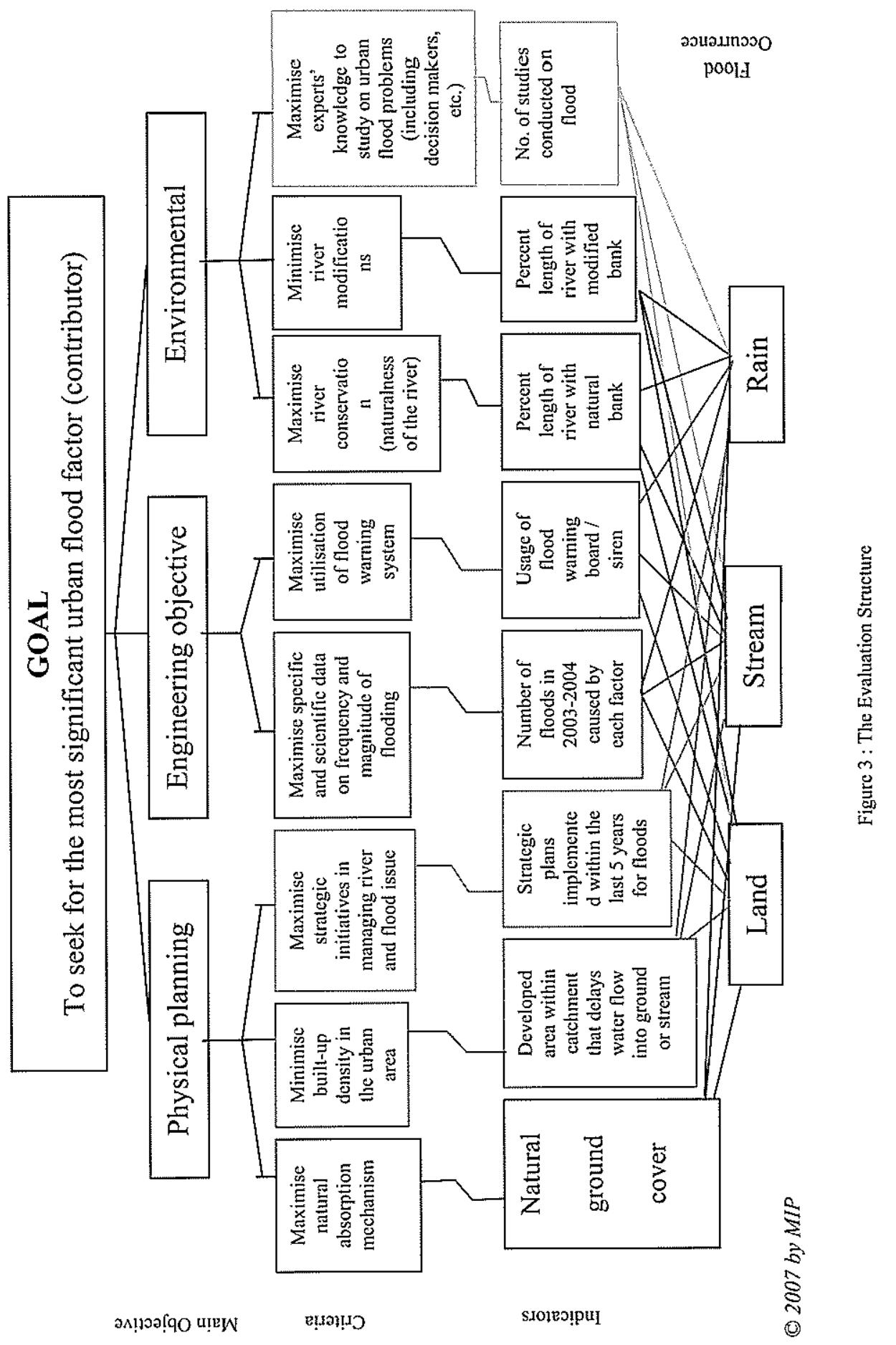


Table 5: Effects table showing performance of each flood occurrence factor - DID, Kuala Lumpur

\begin{tabular}{|c|c|c|c|c|}
\hline Department of Irigation and? & Unit & Land & Stream & Rain \\
\hline \multicolumn{5}{|c|}{ PHYSICAL PLANNING OBJECTIVES } \\
\hline \multicolumn{5}{|c|}{ i. $\quad$ Maximise natural absorption mechanism } \\
\hline $\begin{array}{l}\text { Natural ground cover designated } \\
\text { to prevent flood (for each flood } \\
\text { factor) }\end{array}$ & $\%$ & 12 & 15 & 0 \\
\hline \multicolumn{5}{|c|}{ j. Minimise built-up density in the urban area } \\
\hline $\begin{array}{l}\text { Developed area within catchment } \\
\text { that delays water flow into } \\
\text { ground or stream }\end{array}$ & $\%$ & 80 & 15 & 5 \\
\hline \multicolumn{5}{|c|}{ k. Maximise strategic initiatives in managing river and flood issue } \\
\hline $\begin{array}{l}\text { Strategic plans implemented } \\
\text { within the last } 5 \text { years (for flood } \\
\text { mitigation) }\end{array}$ & $\begin{array}{l}\text { No. of } \\
\text { strategies }\end{array}$ & 2 & 1 & 0 \\
\hline \multicolumn{5}{|l|}{ ENGINEERING OBJECTIVES } \\
\hline \multicolumn{5}{|c|}{$\begin{array}{l}\text { 1. Maximise specific and scientific data on frequency and magnitude of } \\
\text { flooding }\end{array}$} \\
\hline $\begin{array}{l}\text { Number of floods in } 2003-2004 \\
\text { caused by each factor }\end{array}$ & $\begin{array}{l}\text { No. of } \\
\text { events }\end{array}$ & 0 & 0 & 5 \\
\hline \multicolumn{5}{|c|}{ m. Maximise utilisation of flood warning system } \\
\hline $\begin{array}{l}\text { Usage of flood warning board / } \\
\text { siren in } 2003-2004\end{array}$ & $\begin{array}{l}\text { No. of } \\
\text { times }\end{array}$ & 3 & 3 & 0 \\
\hline \multicolumn{5}{|c|}{ ENVIRONMENTAL OBJECTIVES } \\
\hline \multicolumn{5}{|c|}{ n. Maximise river conservation (naturalness of the river) } \\
\hline $\begin{array}{l}\text { Percent length of river with } \\
\text { natural bank }\end{array}$ & $\%$ & 30 & 5 & 0 \\
\hline \multicolumn{5}{|l|}{ o. Minimise river modifications } \\
\hline $\begin{array}{l}\text { Percent length of river with } \\
\text { modified bank }\end{array}$ & $\%$ & 70 & 95 & 0 \\
\hline \multicolumn{5}{|c|}{$\begin{array}{l}\text { p. Maximise experts' knowledge to study on urban flood problems (including } \\
\text { decision makers, stakeholders, engineers and planners) }\end{array}$} \\
\hline $\begin{array}{l}\text { No. of studies conducted on flood } \\
\text { in the last } 5 \text { years }\end{array}$ & $\begin{array}{l}\text { No. of } \\
\text { studies }\end{array}$ & 0 & 0 & 0 \\
\hline
\end{tabular}


Table 6: Effects table showing performance of each flood occurrence factor - DOE, Kuala Lumpur

\begin{tabular}{|c|c|c|c|c|}
\hline Department of Environment & Unit & Land & Stream & Rain \\
\hline \multicolumn{5}{|l|}{ PHYSICAL PLANNING OBJECTIVES } \\
\hline \multicolumn{5}{|l|}{ a. Maximise absorption of excess water } \\
\hline $\begin{array}{l}\text { Natural ground cover designated } \\
\text { to prevent flood (for each flood } \\
\text { factor) }\end{array}$ & $\%$ & 7 & 30 & 5 \\
\hline \multicolumn{5}{|c|}{ b. Minimise built-up area density in the urban area } \\
\hline $\begin{array}{l}\text { Developed area within catchment } \\
\text { that delays water flow into } \\
\text { ground or stream }\end{array}$ & $\%$ & 75 & 15 & 3 \\
\hline \multicolumn{5}{|c|}{ c. Maximise strategic initiatives in managing river and flood issue } \\
\hline $\begin{array}{l}\text { Strategic plans implemented } \\
\text { within the last } 5 \text { years (for flood } \\
\text { mitigation) }\end{array}$ & $\begin{array}{l}\text { No. of } \\
\text { strategie } \\
\text { s }\end{array}$ & 3 & 2 & 0 \\
\hline \multicolumn{5}{|c|}{ ENGINEERING OBJECTIVES } \\
\hline \multicolumn{5}{|c|}{$\begin{array}{l}\text { d. Maximise specific and scientific data on frequency and magnitude of } \\
\text { flooding }\end{array}$} \\
\hline $\begin{array}{l}\text { Number of floods in } 2003-2004 \\
\text { caused by each factor }\end{array}$ & $\begin{array}{l}\text { No. of } \\
\text { events }\end{array}$ & 3 & 2 & 3 \\
\hline \multicolumn{5}{|c|}{ e. Maximise utilisation of flood warning system } \\
\hline $\begin{array}{l}\text { Usage of flood warning board / } \\
\text { siren in 2003-2004 }\end{array}$ & $\begin{array}{l}\text { No. of } \\
\text { times }\end{array}$ & 0 & 3 & 5 \\
\hline \multicolumn{5}{|c|}{ ENVIRONMENTAL OBJECTIVES } \\
\hline \multicolumn{5}{|c|}{ f. Maximise river conservation (naturalness of the river) } \\
\hline $\begin{array}{l}\text { Percent length of river with } \\
\text { natural bank }\end{array}$ & $\%$ & 15 & 15 & 70 \\
\hline \multicolumn{5}{|l|}{ g. Minimise river modifications } \\
\hline $\begin{array}{l}\text { Percent length of river with } \\
\text { modified bank }\end{array}$ & $\%$ & 15 & 80 & 5 \\
\hline \multicolumn{5}{|c|}{$\begin{array}{l}\text { Maximise experts' knowledge to study on urban flood problems (including } \\
\text { decision makers, stakeholders, engineers and planners) }\end{array}$} \\
\hline No. of studies conducted on flood & $\begin{array}{l}\text { No. of } \\
\text { studies }\end{array}$ & 0 & 0 & 0 \\
\hline
\end{tabular}


Table 7: Effects table showing performance of each flood occurrence factor - DBKL

\begin{tabular}{|c|c|c|c|c|}
\hline Kuala Lumpur City Hall & Unit & Land & Stream & Rainfall \\
\hline \multicolumn{5}{|l|}{ PHYSICAL PLANNING OBJECTIVES } \\
\hline \multicolumn{5}{|l|}{ a. Maximise absorption of excess water } \\
\hline $\begin{array}{l}\text { Natural ground cover } \\
\text { designated to prevent flood (for } \\
\text { each flood factor) }\end{array}$ & $\%$ & 30 & 10 & 20 \\
\hline \multicolumn{5}{|c|}{ b. Minimise built-up area density in the urban area } \\
\hline $\begin{array}{l}\text { Developed area within } \\
\text { catchment that delays water } \\
\text { flow into ground or stream }\end{array}$ & $\%$ & 10 & 35 & 55 \\
\hline \multicolumn{5}{|c|}{ c. Maximise strategic initiatives in managing river and flood issue } \\
\hline $\begin{array}{l}\text { Strategic plans implemented } \\
\text { within the last } 5 \text { years (for flood } \\
\text { mitigation) }\end{array}$ & $\begin{array}{l}\text { No. of } \\
\text { strategies }\end{array}$ & 1 & 1 & 0 \\
\hline \multicolumn{5}{|l|}{ ENGINEERING OBJECTIVES } \\
\hline \multicolumn{5}{|c|}{$\begin{array}{l}\text { d. Maximise specific and scientific data on frequency and magnitude of } \\
\text { flooding }\end{array}$} \\
\hline $\begin{array}{l}\text { Number of floods in } 2003-2004 \\
\text { caused by each alternative }\end{array}$ & $\begin{array}{l}\text { No. of } \\
\text { flood }\end{array}$ & 0 & 2 & 3 \\
\hline \multicolumn{5}{|c|}{ e. Maximise utilisation of flood warning system } \\
\hline $\begin{array}{l}\text { Usage of flood warning board / } \\
\text { siren in } 2003-2004\end{array}$ & $\begin{array}{c}\text { No. of } \\
\text { times }\end{array}$ & 0 & 5 & 5 \\
\hline \multicolumn{5}{|c|}{ ENVIRONMENTAL OBJECTIVES } \\
\hline \multicolumn{5}{|c|}{ f. Maximise river conservation (naturalness of the river) } \\
\hline $\begin{array}{l}\text { Percent length of river with } \\
\text { natural bank }\end{array}$ & $\%$ & 10 & 5 & 0 \\
\hline \multicolumn{5}{|l|}{ g. Minimise river modifications } \\
\hline $\begin{array}{l}\text { Percent length of river with } \\
\text { modified bank }\end{array}$ & $\%$ & 15 & 90 & 0 \\
\hline \multicolumn{5}{|c|}{$\begin{array}{l}\text { h. Maximise experts' knowledge to study on urban flood problems (including } \\
\text { decision makers, stakeholders, engineers and planners) }\end{array}$} \\
\hline $\begin{array}{l}\text { No. of studies conducted on } \\
\text { flood }\end{array}$ & $\begin{array}{l}\text { No. of } \\
\text { studies }\end{array}$ & 1 & 1 & 0 \\
\hline
\end{tabular}


Table 8: Effects table showing performance of each flood occurrence factorMMD, Kuala Lumpur

\begin{tabular}{|c|c|c|c|c|}
\hline Malaysia Meteorology Department & Unit & Land & Stream & Rain \\
\hline \multicolumn{5}{|l|}{ PHYSICAL PLANNING OBJECTIVES } \\
\hline \multicolumn{5}{|l|}{ a. Maximise absorption of excess water } \\
\hline $\begin{array}{l}\text { Natural ground cover designated } \\
\text { to prevent flood (for each flood } \\
\text { factor) }\end{array}$ & $\%$ & 0 & 10 & 20 \\
\hline \multicolumn{5}{|c|}{ b. Minimise built-up area density in the urban area } \\
\hline $\begin{array}{l}\text { Developed area within catchment } \\
\text { that delays water flow into } \\
\text { ground or stream }\end{array}$ & $\%$ & 40 & 10 & 10 \\
\hline \multicolumn{5}{|c|}{ c. Maximise strategic initiatives in managing river and flood issue } \\
\hline $\begin{array}{l}\text { Strategic plans implemented } \\
\text { within the last } 5 \text { years (for flood } \\
\text { mitigation) }\end{array}$ & $\begin{array}{l}\text { No. of } \\
\text { strategie } \\
\mathrm{s}\end{array}$ & 0 & 0 & 1 \\
\hline \multicolumn{5}{|c|}{ ENGINEERING OBJECTIVES } \\
\hline \multicolumn{5}{|c|}{$\begin{array}{l}\text { d. Maximise specific and scientific data on frequency and magnitude of } \\
\text { flooding }\end{array}$} \\
\hline $\begin{array}{l}\text { Number of floods in 2003-2004 } \\
\text { caused by each factor }\end{array}$ & $\begin{array}{l}\text { No. of } \\
\text { flood }\end{array}$ & 0 & 2 & 2 \\
\hline \multicolumn{5}{|c|}{ e. Maximise utilisation of flood warning system } \\
\hline $\begin{array}{l}\text { Usage of flood warning board / } \\
\text { siren }\end{array}$ & $\begin{array}{l}\text { No. of } \\
\text { times }\end{array}$ & 0 & 0 & 2 \\
\hline \multicolumn{5}{|l|}{ ENVIRONMENTAL OBJECTIVES } \\
\hline \multicolumn{5}{|c|}{ f. Maximise river conservation (naturalness of the river) } \\
\hline $\begin{array}{l}\text { Percent length of river with } \\
\text { natural bank }\end{array}$ & $\%$ & 50 & 50 & 0 \\
\hline \multicolumn{5}{|l|}{ g. Minimise river modifications } \\
\hline $\begin{array}{l}\text { Percent length of river with } \\
\text { modified bank }\end{array}$ & $\%$ & 50 & 50 & 0 \\
\hline \multicolumn{5}{|c|}{$\begin{array}{l}\text { h. Maximise experts' knowledge to study on urban flood problems (including } \\
\text { decision makers, stakeholders, engineers and planners) }\end{array}$} \\
\hline No. of studies conducted on flood & $\begin{array}{l}\text { No. of } \\
\text { studies }\end{array}$ & 0 & 0 & 2 \\
\hline
\end{tabular}

\section{Multicriteria Analysis}

After completing the objective information in the effects tables, the three flood factors were computed and analysed to show the overall performance of the flood factors. Because the indicators used to measure the performance of each factor have different units of measurement with varying magnitudes, before any 
further processing can be done, they are put through a standardisation procedure reflecting the accuracy of each of the three flood factors. At the next step the standardised indicator scores of the factors were aggregated into a composite index representing the overall accuracy of each flood factor. These overall performance scores are used to rank the three factors. The overall performance of the flood factors is shown in Figure 4, 5, 6, 7, and 8 in the following pages. The boxes similar to a bar graph are a graphic presentation of the indicators in the effects table. The higher the box is, the better the performance.

Figure 4 shows the scores of DID as mostly for land and stream factors. The DOE in Figure 5 is somewhat more balanced on average for the three factors, although for the separate indicators there are significant differences. DBKL as depicted in Figure 6, and MMD as shown in Figure 7, have markedly higher scores for the land and rain factors respectively. Figure 8 shows the overall performance of all authorities on each flood factor. 


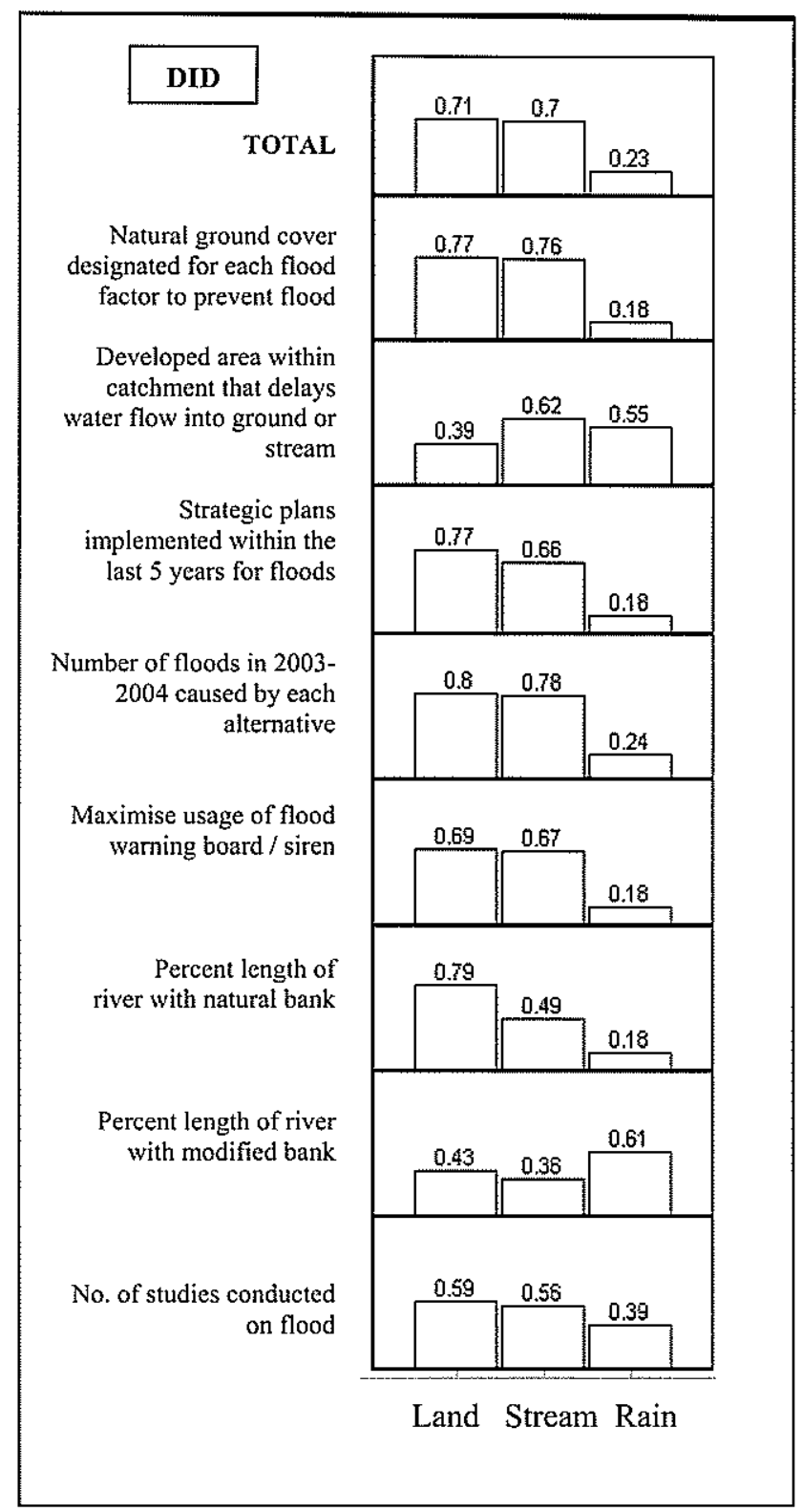

Figure 4: The overall performance of each factor on different indicators (equal weight for each objective) - Department of Irrigation and Drainage 


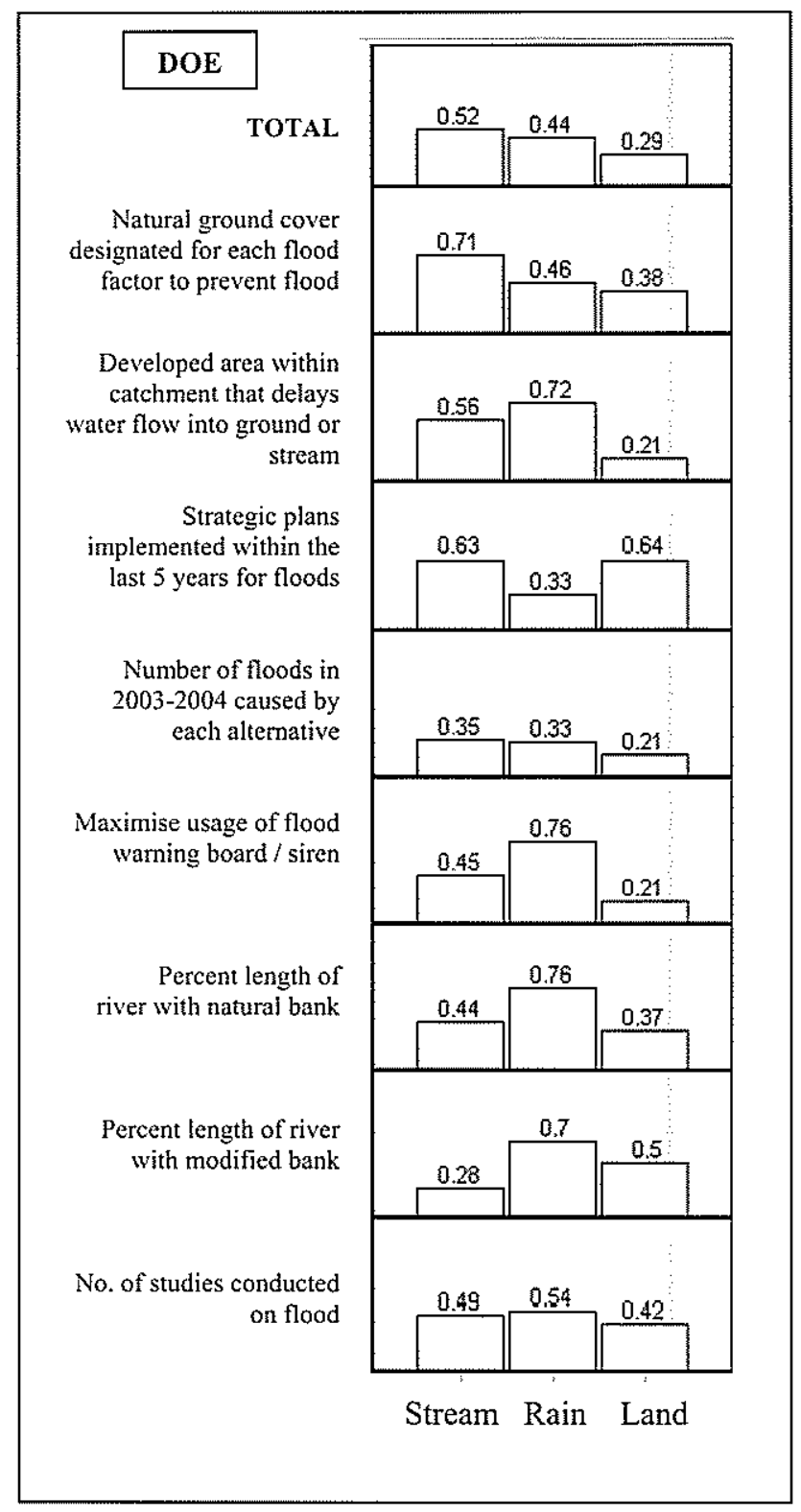

Figure 5: The overall performance of each factor on different indicators (equal weight for each objective) - Department of Environment 


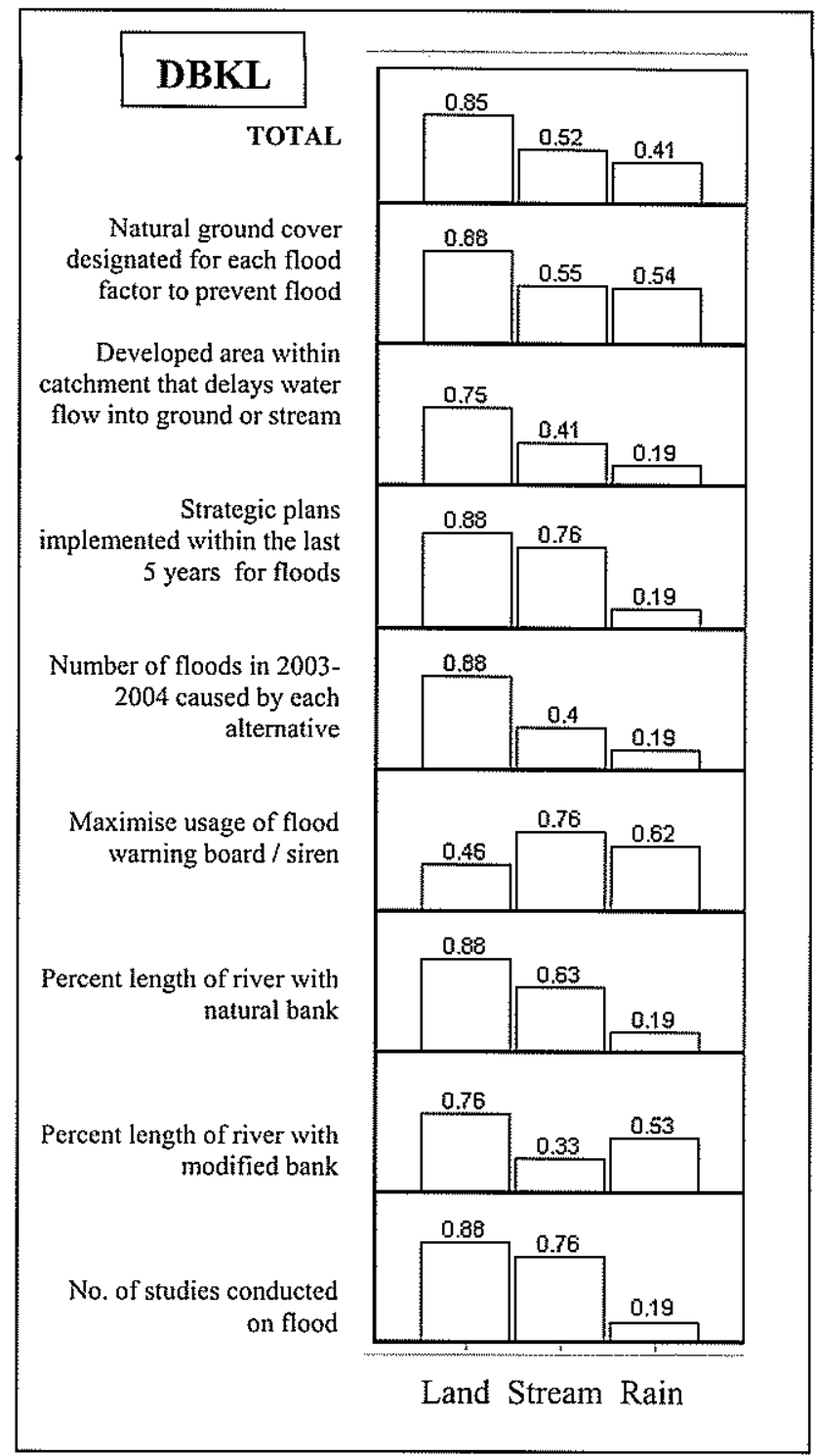

Figure 6: The overall performance of each factor on different indicators (equal weight for each objective) - City Hall Kuala Lumpur 


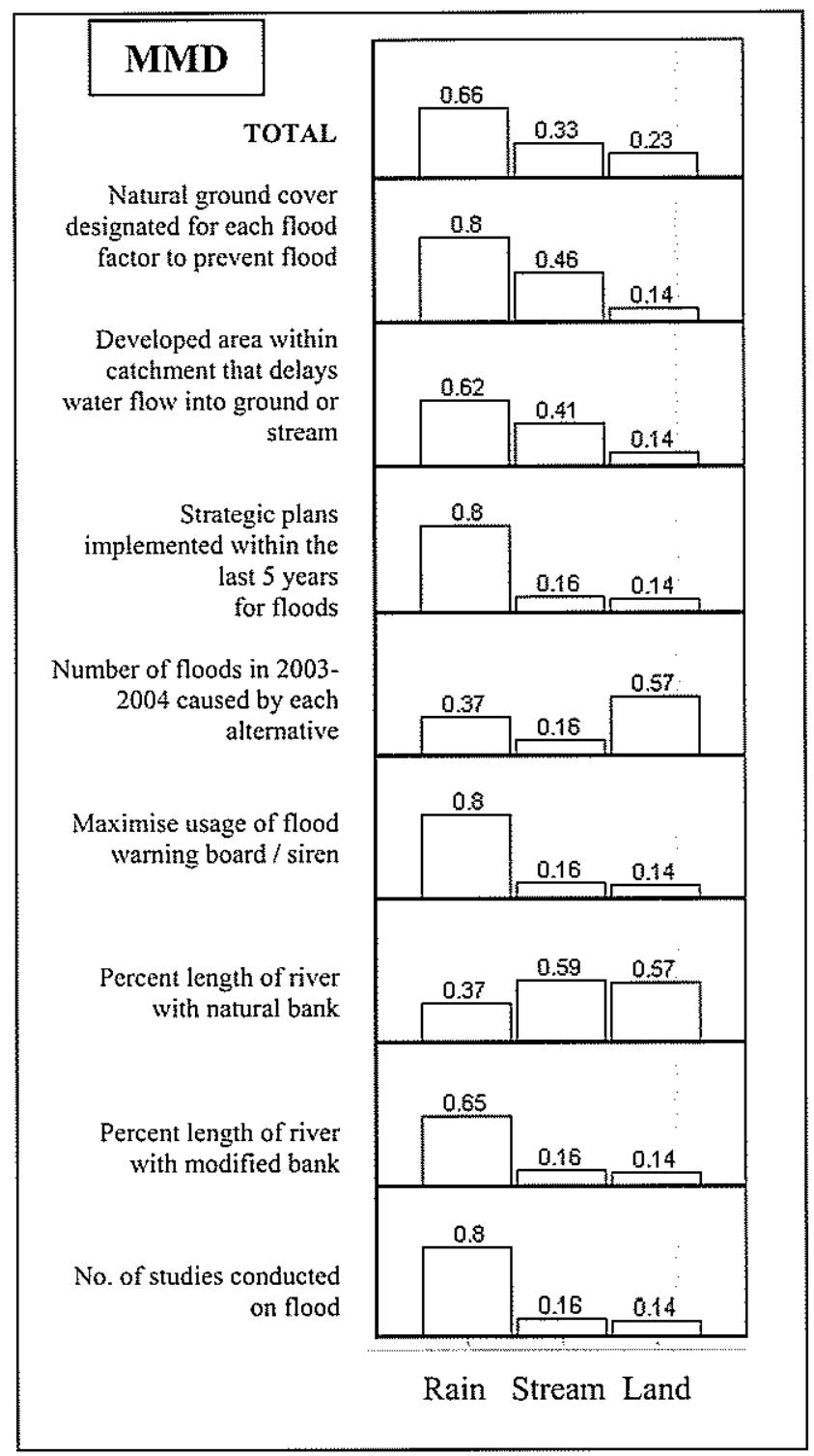

Figure 7: The overall performance of each factor on different indicators (equal weight for each objective) - Malaysian Meteorological Service 


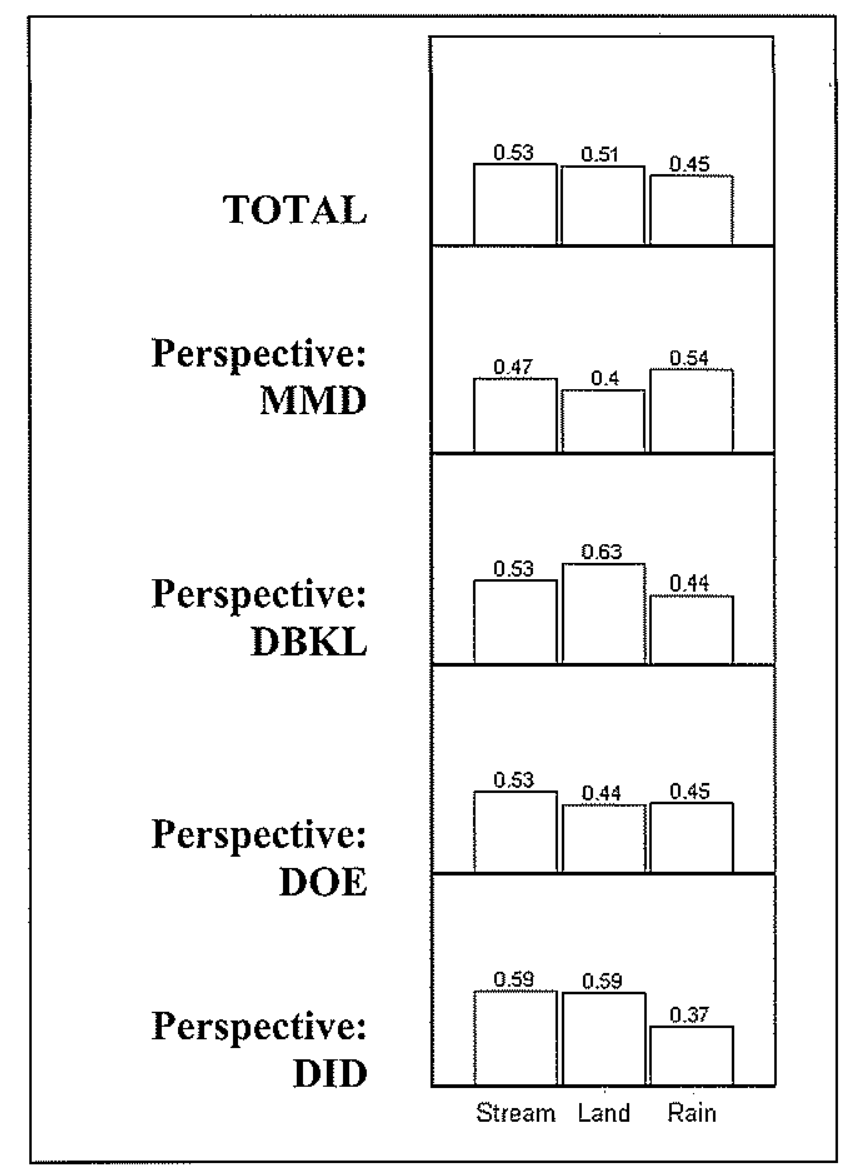

Figure 8: Overall performance of all authorities on each flood factor

From the standardisation procedure resulting in overall performance of the effects table, the performance of each indicator is now tested on the flood factors through a more detailed pairwise comparison of the importance of the effects. This second pairwise comparison has each representative assigning weights resulting in a "weighted summation'. 'Weights' is the value assigned to each effect in comparison to other effects. The standardized values of the effects are multiplied with the effective weights of the effects. The flood factor with the highest score is considered the best. The pie corresponds to the results bar, which eventually shows the flood factor of choice of the authorities.

Unlike the first structured pairwise comparison that resulted in physical planning as being the strongly important objective, the weighted summation shows a different aspect. The DOE representative's estimation from the effects 
table shows the weighted summation results as 'stream' being the main flood factor. On the other hand, MMD representative's estimation shows the weighted summation results as 'rain'. In this aspect, DOE and MMD seem to present opposing estimation as compared to their priority assessment results.

Figure 9 shows the overall rank of each flood factor tallied to the authorities based on the previous weight summation exercise. This is to show that stream factor emerged as the first ranked flood factor, closely followed by land factor.

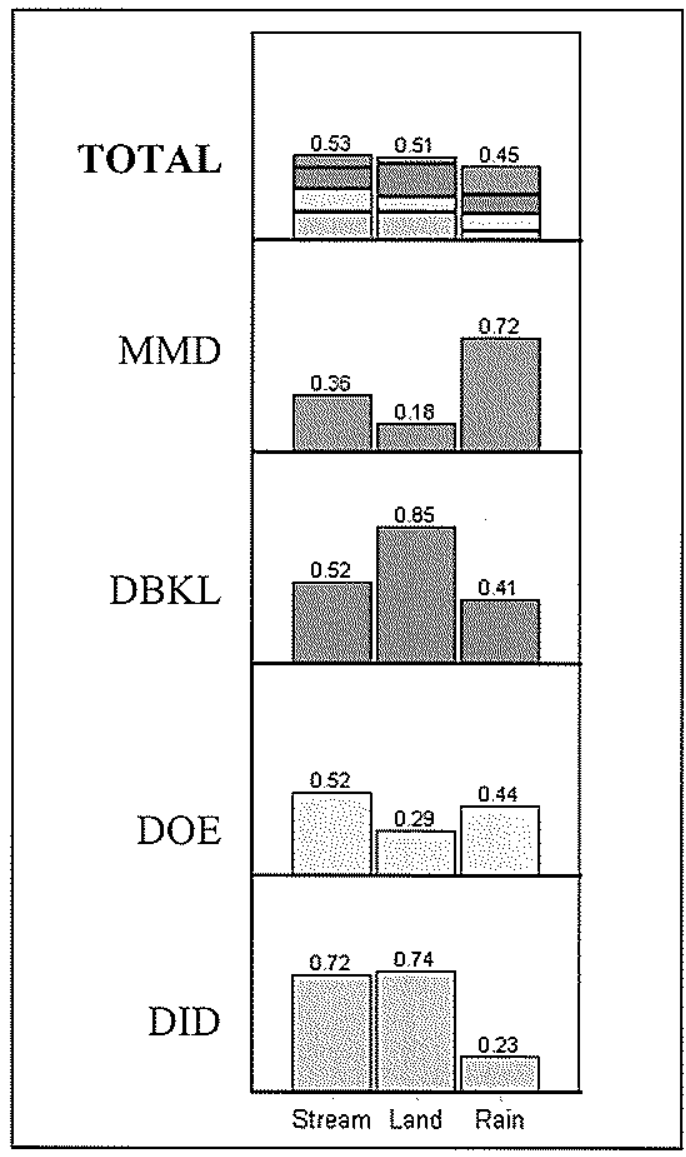

Figure 9: Overall rank of all authorities on each flood factor 


\section{CONCLUSION}

Ackoff's (1977) warning that 'an optimal solution is not an optimal solution to a problem unless a model is a perfect representation of a problem' rings true. From many dimensions such as literatures, public opinion surveys, questionnaires, etc., it is obvious that a flood is caused by any of these three major factors i.e. land, stream, and rain. This study proves that it can demonstrate a systematic approach to evaluate the major causes of urban floods.

Several conclusive outcomes can be emphasised. Firstly, through the pairwise comparison, all the four authorities agree that physical planning is the principal objective in solving flood problems in Kuala Lumpur. Secondly, the results of MCA show two out of four authorities choosing 'land' factor as the primary cause of flooding in urban area. However, the total score for 'stream' factor is slightly higher than 'land' factor even if it is the primary choice of only one authority. Thirdly, in terms of weight assignment of indicators, three out of four authorities assigned the highest weights on those indicators originating from physical planning objective in the criteria structure.

The connection between the results of pairwise comparison and MCA generally correspond to each other. Physical planning as the principal objective is consistent with 'land' factor, as in this study 'land' is a broad term for urbanisation, which is an aspect of physical planning. Thought there is no right or wrong answers, from the background study of the previous chapters it appears that the 'land' factor is indeed the topmost priority in controlling the flood problem because it is within our control.

As opposed to 'stream' and 'rain' which are natural elements that are difficult for man to change, 'land' is the only factor here that is governed by man-made laws, subject to man's activities and is directly within our control. 'Stream' and 'rain' are not $100 \%$ within our control even in terms of forecast; therefore, although each authority sets it as a priority, it does not justify their choice of physical planning as the main objective. The soil on riverbanks is naturally absorbent and can retain water. A river that is still flowing in its original form is able to retain water without bursting its banks during light rain. It is this characteristic of the river that we have to preserve by keeping the soil free from unnatural and impervious surfaces. 


\section{REFERENCES:}

Alias Abdullah et al. 2004. 'Spatial Planning and Decision Support System for Modelling Water Resources' in Water Environmental Planning: Towards Integrated Planning and Management of Water Resources for Environmental Risks, IIUM, Kuala Lumpur, pp 261-282.

Ali Sharifi et al. 2004. 'Evaluating Rail Network Options Using Multiple Criteria Decision Analysis: Case Study Klang Valley, Malaysia' in Applications of Planning and Decision Support Systems, IIUM, Kuala Lumpur, pp 21-60.

Salmah Zakaria 2004. 'Integrated River Basin Management' in Water Environmental Planning: Towards Integrated Planning and Management of Water Resources for Environmental Risks, IIUM, Kuala Lumpur, pp 1944.

Malczewski, Jacek 1999. GIS and Multicriteria Decision Analysis, John Wiley \& Sons Inc, New York.

Asakawa S. et al. 2004. 'Landscape change and the urbanisation process in Europe' in International Journal of Landscape and Urban Planning, Vol. 67, Elsevier, pp. 9-26.

Asian Development Bank 2002. Handbook on Environment Statistics, ADB

Davide Geneletti 2005. 'Multicriteria analysis to compare the impact of alternative road corridors: a case study in northern Italy' in Impact Assessment and Project Appraisal, Vol. 23, Beech Tree Publishing, pp. $135-146$ 


\title{
URBAN HOUSING DEVELOPMENT: TOWN PLANNING ISSUES
}

\author{
Ibrahim Mohd@Ahmad', Ezrin Arbin \& Ahmad Ramly \\ Faculty of Built Environment \\ UNIVERSITY OF MALAYA
}

\begin{abstract}
Town planning is seen to have imposed some degree of constraint on housing development and is discussed in a voluminous literature on the relationship between the planning system and housing land supply. The constraints are believed to have partly contributed to the increase in housing production costs leading to a mismatch between housing supply and demand. Since the government has entrusted the private sector to play an important and bigger role to meet housing needs, local planning authorities and planners should be more cautious in fulfilling their role in housing development. This paper attempts to raise some pivotal aspects of town planning that relate to the problems associated with housing land development in West Malaysia. The primary data was gathered through personal interviews with selected housing developers and analyzed using the factor analysis tool in SPSS. The result of the analysis shows that several aspects of town planning are strongly correlated with development plans and development control factors particularly on land identified for housing, layout plan approval and complying with planning standards.
\end{abstract}

Keywords: Town Planning Issues, Housing Developers, Development

\section{INTRODUCTION}

Owning a house is a gift to a family (Murie, 1976). To own a house, a family can either buy a house on a piece of land or in a high rise building or build a new house on their land. In urban areas, a family has less opportunity to build a home of their own except in traditional villages, self-help housing schemes such as in Salak Selatan, Kuala Lumpur and in squatter areas. However, squatter houses are considered illegal structures sitting on illegal land. Therefore, most inhabitants have more opportunities to buy houses in housing schemes where houses are built in various types such as flat, terrace, semi-detached and detached along with planning and building approval. All houses are made of concrete and roof tiles - the so called conventional type of housing.

\footnotetext{
${ }^{1}$ He can be contacted at ibrahim@mail.alambina.um.edu.my .
} 
Unfortunately, not all urban inhabitants (families, couples, bachelors) are able to live in such housing schemes because houses in the market are sold at the prices beyond their affordability. In big cities like Kuala Lumpur, about $30 \%$ of families living in squatter areas manifest that they were unable to buy houses in the market (CHKL, 2000). In this respect, many studies were carried out especially in the field of low cost and affordable housing. Based on their reports, inadvertently, the town planning was seen to be one of the factors that affect house prices (Agus, 1992; Chan, 1997; Marbeck, 1997, Ghani and Lee, 1997; Khairuddin, 2002). This is because in the housing production process, various stages are involved that, among others, include: schematic and layout submission; planning submission; and building submission. Thus, delays in the approval process, conditions specified in the approval and amendments required to the plan would have resulted in extra production costs compared to the initial proposal. Subsequently, the house prices would be set above the production costs.

From the economic point of view, the price of a property is determined by the property market - namely the supply and demand. The supply of new houses depends upon factors of production costs namely: land prices, building materials, labor wages, and management costs (Ghani and Lee, 1997). When the production cost is higher than the price, developers do not go ahead with the housing project, resulting less housing supply. The house prices of the existing housing stock will increase due to high demand (Harvey, 1992). The high demand for housing was seen during the economic booms when households had more disposable incomes. Conversely, the low housing demand was experienced during the economic recessions. The indication of the high demand for housing based on the economic cycle, boom and burst, can not be easily responded by housing developers because various factors affected their production along the development process (Simon and Henneberry, 2002). Among the factors was urban planning control because all development must obtain planning permission.

The planning permission for all development can only be obtained from the local planning authorities. These authorities, in West Malaysia, are empowered by the Town and Country Planning Act 1976 (Act 172) and its amendments, except for Federal Territory Kuala Lumpur, of which the planning law is called the Federal Territory (Planning) Act 1982. Thus, the planning authorities, as provided by law, are trying to implement the related and relevant government policies as well as to achieve the common planning objectives namely to provide the right site, at the right time, in the right place, for the right people which ultimately creates conducive urban environment for inhabitants and economic activities (Ratcliffe, 1981). 
Hence, all development of either merely one unit or more houses must obtain planning permissions and building approvals. The latter is actually not a function under the Town and Country Planning Act but it is under the Street, Drainage and Building Act 1974. In the process of getting these approvals there have been many issues raised up by those related studies. Among the most popular issues highlighted are the delays in obtaining the approvals. The claims, however, do not identify which planning factors cause problems and additional costs to the housing development or whether town planning causes are more problematic than the other factors, or 'planning problems' as mentioned may not refer to the actual planning activities but the building control under the planning department.

Therefore, the objectives of this paper are: first, to identify the subject of town planning control that cause difficulties to housing developers in developing housing estates from the view points of housing developers in West Malaysia; and the second, to identify the dimension of the interrelated constraint factors concerning the housing development associated with urban planning control in West Malaysia. In order to achieve these objectives, the discussion starts with the planning for housing as the background for housing provision and delivery system and followed by literature on planning constraints in developing housing and end with findings and conclusion.

\section{PLANNING FOR HOUSING}

There have been various efforts by the government to provide adequate housing or to meeting housing needs especially in major towns in Malaysia. In the early independent period, the government had highlighted the importance of providing public housing for the urban poor. Then, this effort was followed by the allocation of government funds to local authorities and financial institutions. The rate of interests and loan repayment periods were also touched. The high urban growth rates between 1960 s and 1970 s were seen as one of factors undermining the effort to provide adequate housing (Ozay, M 1988, Johari, M.Y 1991). The proliferation of squatter housing in major urban areas stimulated the government to solve the problems. In the Third Malaysia Plan (1976-1980), the government set the significant objective in the housing sector. The main objective was to have all Malaysians living in decent homes. The general definition of a decent home was referred to a house that provides safety, healthy, security, has adequate basic facility and has high accessibility to community facilities and amenities. In order to achieve these objectives, the government also realized that a home to a family must be within the affordable 
prices. Accordingly, the government outlined many measures to be implemented within the period of all the following Five year Malaysia plans. Among the measures were: the arrangement of finance for the owner occupier, identifying key players and encouraging private sector involvement. Looking at these measures, it seems that the government is more concerned with the conventional type of houses when it formulated housing objectives. In the Seventh Malaysia Plan (1995-2000), the targeted houses to be built were 800,000 units of which 71 percent will be built by the private sector. In the Eight Malaysia Plan (2001-2005), the objective of housing development program was "to increase accessibility to adequate, affordable and quality houses for all income groups. Priority will continue to be given to the development of low- and low medium-cost houses". To meet this objective, it was expected that the public and private sectors will intensify their efforts to meet the increasing demand. However, at the end of the plan period, the Bank Negara Annual Report 2005 highlighted that the number of houses built exceeded the target in the medium and high cost category. Until the end of year 2005 , there were 17,000 units of houses unsold.

In this context, the private sector involvement becomes an issue because it is well known fact that it main interest is to make lucrative profits. Any cost incurred in producing houses will be transferred to the buyers and the profit margin yielded should be higher than in other sectors (Harvey, 1992). To get the acceptable affordable price of houses or low cost housing, the government was asked to provide more "state land" to housing developers and to expedite the planning approval process (Chan, 1997). Without cheaper premium for land or free land, housing areas were moving out from the urban centers to the fringes mainly by converting the agriculture lands of the private properties. The planning control is, from this point of view, seemed to be more relax. More land released for housing means that planning gives approval to all conversion involving agriculture land. However, this approach does not guarantee the desired effect on house prices because the study in the UK has shown that large acreage of land release for housing development did not favorably change the house prices (Healey, 1992; Bramley, 1993). In addition, housing developers would have embraced more problems in developing agriculture land to be housing estates since the site was outside the local authority boundaries is not covered under any development plan. Even though the site was located within the local authority boundary, it was probably not in the residential zone. This is where the planning constraints exist. 


\section{PLANNING CONTROLS IN HOUSING DEVELOPMENT}

According to the development process, the housing project begins with the land acquisition stage and ends with the selling of houses built. Hence, the planning control comes in at the process of getting statutory approvals (Khairuddin, 2002). Within the development process, the planning constraints only appear when an application for approval is submitted to the local planning authorities or to land offices. In identifying the constraints, it is easier and clearer to discuss them by looking at the housing estate development rather than at the development of a small portion land for housing because housing estates involve large acreage of land area and comprise variety element of land uses.

Housing estates are being developed every where either within the town boundary or its outskirts. Their location, usually, are adjacent to the existing major roads or small towns. Most of the estates are developed after the conversion from agriculture to building category or by filling up the existing mining ponds. The developers would have carried out feasibility study and financial appraisal by which they would be able to gauge the 'yield' of the proposed projects prior the application for planning permission (Simon and Henneberry, 2002). The prospective developer must have adequate capital to proceed with the project. Financial aid can be obtained through bridging-finance facilities with certain interest rates.

The conversion from agriculture to building is under the prerogative of the states where it is delegated to the land offices concerned. In this respect, state town planning offices and the local planning authorities are only asked for recommendations. This requirement is set in the National Land Code 1965 (NLC). Under the NLC, the state may confer a piece of land to an individual or to a company with the specific category attached viz: Agriculture, Building, and Industry. Any change of usage that differs from the said category listed, needs approval from the land offices. According to the Real Estate and Housing Developer Association (REHDA), the time needed for the process of getting approvals from the from the Land Office is highly unpredictable because it comprises of various activities on the part of the government, technical departments such as Tenaga Nasional Bhd., Indah Water Consortium, PUAS and local planning authorities. There were cases where the time taken from the submission up to the approval stage spent more than 2 years (Marbeck, 1997).

The planning office must refer to the development plan of the area before giving consent to the land conversion. The development plan, either Structure Plan or Local Plan if any, identifies the land for housing in the form of new growth areas and attached with development policies that include inter-alia allowable 
densities, plot ratio and provisions for community and amenity facilities. To date, most of town and cities in West Malaysia had their Structure Plans and Local Plans prepared before the amendment of Town and Country Planning Act (TCP) 1976 in 1995. The amendments introduced a new development plan system that comprises National Physical Plan for Peninsular Malaysia (West Malaysia), Structure Plan for the states and Local Plan for town and cities. Consequently, if the land applied was not within the identified area, the planning office would not give approval. So far, the land office has never overruled the planning office for the land conversion approval (Roslan, 2002).

After the land has been converted, the application for the lay out plan approval must be obtained from the local planning authorities. The planning authority may not necessarily be the local authority of the area but can also be the Land Office if the area is not within the local authority boundary (TCP Act, 1976). In considering application for the layout approval, planning offices have many sorts of guidelines and regulations including the planning standards and policies. The application for conversion and housing layout approval does not seem to be easy, as many housing developers face various kinds of obstacles. For example, an applicant must visit or consult about 20 related technical departments which caused considerable delays in getting approval (Chan, 1997). Besides the technical departments involved in the process, the processing of an application also take a very long times to get the planning decision from the state planning office. The client charter printed several categories of applications and the possible period of getting approval. For the layout plan approval, the possible time should be within 12 months but in actual cases there are many more activities involved between the two parties (Planning offices and the applicant) because matters such as the completed forms, fees paid, drawing scale used, information and EIA report attached, and layout design would require more consultation and discussion that directly cause the delays. In addition, in major cities like Kuala Lumpur the number of planning applications to be tabled to the Town Planning Committee per. week are more than 40 whereas the capacity to make a decision is only for between 20 and 30 applications. So, the backlog applications keep on increasing. Thus, the delays in obtaining planning approval seem to be unavoidable during the economic boom period, although that may not be the case during recession.

The Town Planning Committee or the State Planning Authority may impose several conditions or subjects to be included in the proposed layout plan while considering approval based on the relevant development plans or current 'planning materials'. Among the common subjects are the changes of the proposed density, enlargement or relocation of the proposed community facilities as well as the increase in its numbers, infrastructure improvements or 
additional provisions. These requirements and changes may reduce the buildable site for houses; causes the increase in production costs and problems to the developers for whom the requirements and policies outlined by the development plan may force them to reconsider the proposals because the requirement will inevitably increase the production costs (Simon and Henneberry, 2002).

After the lay out approval, especially for a large housing scheme of more than 200 hectares, the applicant may phase out the scheme and consult the land office to submit application for subdivision of land, strata title and for individual titles according to the phase of development and also together with the Requisite Survey Plan (RS plan). The land office may give the approval after undergoing several steps in the process and technical meetings. Hence, this stage does not involve the urban planning office but only the Land Office. The planning office plays its role again when there are applications for planning permission or for 'development order' (for Federal Territory Kuala Lumpur only) according to the phasing of development as determined by the developers. At the development order stage, the consideration for planning matters would be more detailed. The common subjects are traffic circulations, parking requirements, net residential density and net plot ratio for commercial usage, facilities and utilities. In Kuala Lumpur, the development charges for excess density, excess floor area and lack of car-parking provision are calculated at this stage and must be paid before the permission is released. The decisions made by the Planning Authorities almost always contain conditions imposed by the technical departments.

After obtaining the development order and paying the necessary fees, developers must submit application for building approval. The building control section in the local authorities has its own steps of process. While the application is being considered, the developer is allowed to carry out earth work and land leveling for construction. However, this kind of activities requires permission from the Civil Engineering Office (usually Public Work Department). The time taken for building approval which could be more than a year is not going to be discussed in detail here because it does not come under urban planning jurisdiction.

\section{ISSUES OF URBAN PLANNING AND HOUSING DEVELOPMENT}

Planning can impose conditions in giving out approval. The major contribution to the increase in production costs are the provision of infrastructures and changes of the scheme design (Ghani and Choong, 1997). The infrastructure involving high costs includes the identified viaduct, bypassed and the road 
widening. These types of infrastructure construction would have swallowed much of the capital costs leaving a small portion for the others. Moreover, these result in high loan requirements which subsequently increase the amount paid for interest. The amendment to the design does not only refer to the building design, but also the allocation of land for community facilities and amenities according to the specified standards (Planning Standards and Design Guidelines). The developers have to bear all costs and transfer them to the buyers.

By looking at the possible factors in production cost, town planning authority may alter the land availability for housing if the development plan does not identify the land to be new development areas. This is where the anticipated land requirement for a particular town may not accurately reflect the actual acreage of land needed. This technical error, consequently, would cause the potential land and low price land undeveloped (Buang, 1997). The planning officer may also refuse to give recommendation to the land office for converting agriculture land or redeveloping ex-mining ponds. This action, either consciously or unconsciously, will unintentionally be limiting the amount of land to be converted to residential development. Subsequently, land prices will increase because the land approved for housing can be sold at higher prices (Monk, 1991).

Based on the above discussions, it is possible that Town planning may impose constraints to housing development through the development plan by which the land is identified for future development together with development policies on intensity, designs and land use zoning. Through the development control, the local planning authority sets out procedure to be followed, processing requirements, planning standards and duration of its activities. During the decision making, there is more room for town planning to impose extra conditions or amendments and improvement that need to be complied with. The following discussions based on the analysis of the data collected will encompass the dimensions of the constraints.

\section{DATA COLLECTION AND ANALYSIS}

Information about the planning control applied by state and local planning authorities was gathered through the secondary sources such as books and reports, joumals and seminar papers relating to housing and planning. The objectives outlined in this paper can be achieved by primary data which were obtained from the housing developers because they were the sector facing the problems. Thus, all housing developers become the 'population' for the sample. 
There were 1099 registered housing developers in Peninsular Malaysia in 2004/2005 (REHDA). Due to unavoidable factors that include limited time, lack of financial resources and manpower, only 137 housing developers were interviewed by using sets of structured questionnaires according to the 'proportionate stratified sample' method. This method of sampling is able to get representatives from each stratum (the registered developers in each state). All registered housing developers in each stratum were given a number each and then the sample was drawn by using the statistic random table. The selected housing developers were then traced to their addresses based on their name of establishments in Real Estate and Housing Developer Association (REHDA) Directory Reports. The size of the sample in this case, however, is adequate for statistical analysis because the size of more than $30(>30)$ is considered as a large sample where the 'mean' will be closer to a 'mean' of normal distributed curve for the whole population so long as the population size is at least twice the sample size (Spiegel, 1972. p 142, McClave and Sincich, 2006).

All completed questionnaires were processed by using the SPSS software that enables the process of factor analysis. This method is able to explain the relationship between the items under study. For the factor analysis, there were several important procedures and steps that needed to be followed (Nachmias, 1996). The method assumes that items representing a single dimension will highly correlate with that dimension. Thus, the correlation between item and factor is represented by a "factor loading". A factor loading is similar to a correlation coefficient that can be interpreted the same way.

\section{DISCUSSION OF FINDINGS}

\section{Results of the data analysis}

The data in Table 1 can be interpreted in many ways. However, for the purpose of the method of identifying the significant constraints of the factors, the coefficient or 'loading' of less than 0.3 can be ignored (Mahzan, 2002). The bold figures show the high factor loading where the relationship between the item and the factors is considered strong. The rest of item loadings are too weak to be considered as good indicators of the dimension investigated. Moreover, the factors with the highest percentage of explained variance provide the most parsimonious representation of the items (Nachmias, 1996.p.472). Therefore, the table reveals that the most parsimonious factor is the development plan (existing Structure and Local Plan) with 66.9 percent and the least parsimonious is planning communication and correspondence ( 3.43 percent) excluding the non planning factors. 
Table 1:

Factors of difficulties in housing development

\begin{tabular}{|c|c|c|c|c|c|c|}
\hline Items & F 1 & F 2 & F 3 & F 4 & F 5 & F 6 \\
\hline Land Location & 0.580 & 0.351 & 0.450 & 0.383 & 0.210 & 0.216 \\
\hline Land Constraint & 0.276 & 0.165 & 0.673 & 0.161 & 0.159 & 0.083 \\
\hline Land Holding & 0.319 & 0.228 & 0.270 & 0.203 & 0.633 & 0.127 \\
\hline Land Category & 0.207 & 0.240 & 0.504 & 0.212 & 0.249 & 0.166 \\
\hline Land Size & 0.480 & 0.192 & 0.479 & 0.428 & 0.250 & 0.190 \\
\hline Land Conversion & 0.616 & 0.316 & 0.302 & 0.316 & 0.363 & 0.169 \\
\hline $\begin{array}{l}\text { Land Subdivision } \\
\text { and individual title }\end{array}$ & 0.455 & 0.498 & 0.281 & 0.418 & 0.251 & 0.120 \\
\hline Layout approval & 0.456 & 0.498 & 0.281 & 0.418 & 0.251 & 0.129 \\
\hline Housing density & 0.462 & 0.361 & 0.179 & 0.441 & 0.301 & 0.058 \\
\hline Housing design & 0.379 & 0.300 & 0.279 & 0.678 & 0.210 & 0.156 \\
\hline Road design & 0.298 & 0.691 & 0.162 & 0.188 & 0.176 & 0.097 \\
\hline $\begin{array}{l}\text { Provision of } \\
\text { Community } \\
\text { facilities }\end{array}$ & 0.765 & 0.278 & 0.276 & 0.205 & 0.236 & 0.137 \\
\hline $\begin{array}{l}\text { Provision of } \\
\text { Utilities }\end{array}$ & 0.393 & 0.495 & 0.331 & 0.0 .242 & 0.0 .204 & 0.427 \\
\hline $\begin{array}{l}\text { Open spaces and } \\
\text { recreation }\end{array}$ & 0.752 & 0.280 & 0.281 & 0.237 & 0.185 & 0.156 \\
\hline Landscaping & 0.455 & 0.388 & 0.304 & 0.299 & 0.281 & 0.473 \\
\hline $\begin{array}{l}\text { Percentage of } \\
\text { Variance }\end{array}$ & 66.9 & 5.23 & 5.02 & 3.6 & 3.43 & 2.97 \\
\hline
\end{tabular}

Note: $\mathrm{F}=$ factor loading

Factor 1 represents the difficulties relating to the structure plans and local plan

Factor 2 represents the difficulties relating to the planning standards

Factor 3 represents difficulties relating to procedures in planning applications

Factor 4 represents the difficulties relating to the planning decision,

Factor 5 represents the difficulties relating to the planning communications and correspondents

Factor 6 represents the difficulties relating to non-urban planning roles.

\section{Development Plan (Structure and Local Plan) Factor}

Housing developers are aware of the development plan prepared in the area chosen for their projects because they usually consult their consultants that include town planners and architects. From what Table 1 shows, it is apparent that the policies and concept outlined by the respective development plan are the main cause of difficulties to the developers in developing housing estates. Firstly, regarding the housing land location and the land size, the location chosen for the project must be within the proposed new growth areas. Though 
from the housing developers' point of view, the potential development areas depends upon the economic factors such as the availability of land, low construction costs and demand, their attempts to develop areas other than identified by the development plan become a very risky venture. Those successful housing estates outside the identified growth areas could be considered lucky projects when the location chosen had merits for housing besides those under the special projects providing houses for the hard-core poor group, resettlement schemes and government quarters.

The demand for housing as referred by housing developers is the capability of households to pay for the houses built in that particular area. The sites identified for housing in the development plan to them do not guarantee the housing development will be able to meet the demand. Based on the data obtained from the survey, there were various problems faced by the developers. Housing developers preferred the project site to be close to existing access roads which was an ideal site. The site should also be accessible to the existing infrastructure laid down such as electricity, water supply and sewerage line. Without the existence of basic infrastructure in the area, the housing developers have to face the problems of dealing with the private land owners to erect the necessary infrastructure as required for the development. Therefore, when asked about land preferred for development in such areas, developers/ respondents prefer the road frontage lands to be developed first before they can start looking at the following inner land (second lot from the road side). Developers' experience showed that there were sites suitable for housing development but the access roads had to be erected through private lands. In some cases, the access roads had to be constructed wide enough according to the hierarchy of road - main collector 66 feet wide, leaving the balance of such private land with smaller plot. In such circumstances, the respective land owner refused to negotiate either for sale or for rent and rejected the discussion of possible compensation. This problem usually forces the prospective developers to abandon the project even after obtaining the planning permission.

From what has been highlighted by housing developers, in many circumstances, land dealings have caused interruption to the progress of housing projects. The planning control, especially the conditions imposed related to the accessibility, can not be easily complied with. There is also a similar problem in the case of land use zoning. Although the development plan has shown a housing zone, the land cannot be readily used for housing if the infrastructures have not been laid down by the proper authorities. Besides the new roads needed, there was also a case where the prospective housing developers have to negotiate with the frontage land owners for the sharing provision of community facilities and 
utilities. Therefore, it seems that the land zone for housing has been designated on papers without sorting out land matters at the planning stage.

All these answers lead to the size of land that is large enough to enabling housing developers to get acceptable returns from their investments. When questions asked about how much the profit expected from each development, the answer given shows that the majority of housing developers aim at making $30-50 \%$ profits. Developers' previous experiences are also asked in the survey to obtain the factors that bring about the success of the housing development projects. This means that the previous development were able to help developers to make profits as to be able to sell all houses built to house buyers. The most common factors listed by housing developers were the location of the sites, size of the land, the ownership title, subjects and conditions stated on the titles of the land, the reasonable land price and the ability to obtain planning permission.

With regards to the development plan policies, particularly on housing densities, the interpretation of allowable housing density into net and gross density are subjected to personal opinions and become very confusing. Briefly, it is undeniable that the application of the existing development plans has caused difficulties to many items shown in Table 1. The developers usually get to know the housing policy indirectly from the rejection of their planning permission in certain areas and reasons outlined by the local planning authority.

\section{Planning Standard Factor}

Planning standards used by local planning authorities are mostly provided by the Federal Town and Country Planning Department Headquarter in Kuala Lumpur. Their application to the site and location outside Kuala Lumpur may have been considered by the planning office concerned. The problems in complying with these planning standards have been highlighted by the housing developers especially in land sub-division and layout plan approval. The problems are related to the quantity and size of community facilities required. The large land acreage required to provide community facilities limits the number of houses that can be built. Moreover, the land used by community facilities must be surrendered free of charge to the government.

Besides the community facilities, the problems also occurred in complying with road designs and road widths. The road design depends on the neighborhood unit to be created and the security measures considered. Less number of out-let to the housing scheme means better security. The requirement to form efficient traffic circulation may defeat the purpose of security measures. The costs of 
land traded of for roads would not always be covered by the revenue through selling the houses based on the market prices. The other problems and difficulties faced by housing developers are the provisions of public utilities such as electrical sub-stations for Tenaga Nasional Berhad and, sewerage treatment plants. The land required to house these utilities is quite large. The quantity and size also depends on the planning standard. The unhappy developers raised the issue of these requirements because utility providers are no longer public authority and are now under the private companies, whereas the planning standards adopted are from the technical department concerned. Without those utilities, the housing scheme concerned could not be implemented.

\section{Procedures for applications}

The submission for an application for planning permission has to be submitted by a registered town planner or any other professionals allowed under their professional Acts. This requirement is however left to the discretion of the local planning authorities. Since the year 2000, most of the local planning authorities in Peninsular Malaysia have adopted this requirement on the belief that professionals like town planners will take into account the effect of the development on the surrounding physical environment. In addition to the above requirement, housing developers have to prepare cumbersome number of plans, accompanied by Proposed Development Reports (PDR) for the planning application. Sometimes the application is rejected because of some technical mistake such as typing error or wrong figures in the technical calculations, but only a small percentage of housing developers have faced this kind of problem. All items required to be furnished on submission for planning application seem to be well understood by housing developers, except several matters such as Quit Rent and Assessment payment receipts. Reasons given by developers are that quit rent receipts are often not held by the agent for the development as it is merely related to administrative purposes. So why does it become a compulsory requirement? The procedure requiring the agent to attach with the adjoining land owner name and address in planning application may cause an additional difficulty to developers because not all landowners are traceable from the Land Office.

Upon receiving an application for planning permission, the local planning authority begins its function by referring it to technical departments or calling for comments. The local planning authority also processes the application by examining the planning standards, assess the report submitted and looking at the zoning and types of density proposed. It also refers to the development plan policies, local issues and local requirements. If the local planning authority 
finds any doubtful data in the applications such as wrong calculation or unacceptable layout design in the proposal, it may ask the developers to come over to the office for discussions. If both parties reached an agreement, the housing developers will take back the drawings and resubmit the application. The majority of housing developers ( 76 percent) complain that sometimes they had to undergo more than three submission exercise because of amendment to an application.

The time taken for processing application starts from the date the application is received by the planning office and it ends when the applicant is informed about 'approve or disapprove' decision obtained after the State Planning Committee (SPC) meeting. Most of the developers' responses show that they have to wait more than 3 years (Mean-3.5 years) for the feedback. What can be learnt from this is that the charter given to the public is not always complied with. There were cases when even more time taken in the processing, depending upon the individual application. Problematic cases may take longer while the more straightforward one may be shorter. The charter advocated in the planning department is meant for the average cases. The longer time taken, as shown in Table 1 depends on many factors; besides the amendment to be made by the applicant, the process also has to take into account the reply from the applicant for each correspondence, time taken for the applicant to resubmit the amendment, the waiting time for the preparation of the concept or lay out plan for the area concerned, waiting for the adoption of the development plan, waiting for the adoption of the new planning standards or guidelines, waiting for the neighbors' objections, if any, and administrative problems such as shortage of man power. The latter refers to the inadequate number of technical and professional staff to handle the application including to do site inspections, to scrutinize the report and to write comments. In some isolated cases, the applicants have to resubmit all the information and plans because the file was lost or could not be traced. Inevitably the applicant has to comply with such request no matter on what the reason is.

\section{Planning Decision Factor}

Approval without 'subject to fulfillment' can only be obtained by an applicant of a small scale housing development such as less than 5 acres sites. Most planning approvals are given with several conditions imposed. The standard condition used by the local planning authority can be anticipated by housing developers. The majority of them said that the conditions to be fulfilled in getting planning permission have been taken into account in the proposed development. If the condition imposed will cause a high increase in construction 
costs, they usually file for appeal. The appeal for the planning permission granted normally takes another 3-6 months (Mean -4.6).

Housing developers complain that some local planning authorities impose unsatisfactory conditions for housing development. They expect the same types of housing development to have similar conditions. However, they find that there are a variety of requirements have to be satisfied with such as size of play ground, road width and number of community facilities. The year to complete a housing project reflects very well the comments given by the housing developers. Matters are made worse when sometimes the decision making process is changing from year to year. The changes may involve the planning standards used, changes in the administration of the local planning authorities and even changes in planning policies.

\section{Non Urban Planning Factors}

There are many subjects highlighted by housing developers shown by Table 1 (Factor Analysis), that do not fall under planning matters although the questions are confined to urban planning. These non planning matters include detailed technical requirements for road constructions, design of utilities and provision, and landscape design. The developers also highlighted that the difficulties in constructing housing could also be due to several other problems commonly related to finance, land matters and economic factors. With regard to finance, housing developers argue that the financial institutions would like to see the experiences and past performance which can hardly be satisfied by new housing developers. This issue which is not really urban planning matters needs no further elaboration. For the land matters, they refer not only to land ownership and tenure, but also the process of acquiring land and transaction dealings. All these matters do cause problems to developers. Multiple land owners and many interested parties involved in a piece of land would make the developers to shy away and choose other land as an alternative. While the urban area becomes larger and larger, there would be less and less big acreage of land with potentially easy land transactions. The potential area for future housing is ultimately located further out of town facing less demand and lack of infrastructures. The applications for land conversion and subdivision will inevitably involve long processes unless the procedure concerned is improved. The implication of a long process would adversely affect the prospect of the proposal because it may make the project non feasible or non viable due to changes in the market environment and sometimes due to increasing material costs. 


\section{CONCLUSION}

There are cases in which the data cannot be elaborated in detail because the developers did not answer the questions fully. Precautions must also be placed in the interpretation of the data because presumably the private sector has its own hidden agenda. The analysis of the data, however, reveals some indication of the factors covered by urban planning affecting housing development. Even though these findings seem to reflect more negative than positive views, it brings to the fore that these important factors must be taken into consideration in forward planning, controlling development and planning decision concerning meeting the housing needs. The dominant factor seems to be associated with the development plan; in other words it becomes the most important guidance in housing land development. Therefore, Town Planners should be more cautious in their decisions, recommendations, and technical analysis in preparing the development plan,

In addition, the development plan needs to be revised after a certain period of time such as every 5 years in order to be in line with the current economic environment. More importantly, these findings highlight new insight to planning control affecting the housing development.

\section{REFERENCES:}

Agus, M.R. 1992. Pembangunan Perumahan: Isu dan Prospek. DBP. Bank Negara Malaysia. 2000. Annual Repor., Bank Negara Malaysia Bank Negara Malaysia. 2001. Annual Report. Bank Negara Malaysia Bank Negara Malaysia. 2005. Annual Report. Bank Negara Malaysia Barlow, James 1993. Controlling the Housing Land Market: Some example from Europe, Urban Studies, Vol. 30, no.7

Bramley, Glen 1993. Planning, the Market and Private House Building, The Planer, January 1993.

Chan, Lawrence 1997. Government Housing Policies and Incentives: the industry viewpoint. In Housing The Nation: A Definitive Study, Kuala Lumpur, CAGAMAS Bhd.

City Hall Kuala Lumpur 1981. Draft Report of Survey: Kuala Lumpur Structure Plan. Dewan Bandaraya Kuala Lumpur.

City Hall Kuala Lumpur 2000. Report of Survey for Reviewing Kuala Lumpur Structure Plan. Dewan Bandaraya Kuala Lumpur and ISI (UTM).

David Adams and Craig Watkins 2002. Greenfields, Brownfields \& Housing Development. Real Estate Issues, Blackwell Publishing 
Ghani Saleh and Choong Lai Chai. 1997. Low cost Housing: Issues and Problem. In Housing The Nation: A Definitive Study. Kuala Lumpur. CAGAMAS.

Ghani Saleh and Lee Lik Meng. 1997. Low Cost Housing in Malaysia. Utusan Publication and Distributor.

Harvey, Jack. 1992. Urban Land Economics. Macmillan

Healey, P. 1991. Model of the development process: a review. Journal of Property Research. Vol. 8, 219-238

Healey, P. 1992. The Reorganization of State and Market in Planning. Urban Studies. Vol. 29. p. 411-434.

Henneberry, J and Rowley S. 2002. Developers' decisions and property market behaviour. In Simon Guy and John Henneberry. eds. Development and Developers: Perspectives on Property. Real Estates Issues, Blackwell Publishing.

Johari, Mohd. Yaakub Hj. 1990. Urban Poverty in Malaysia, Institute for Development Studies (Sabah); Art Printing Works Sdn. Bhd.

Khairuddin Abdul Rashid. 2002. Construction Procurement in Malaysia, International Islamic University Malaysia, Research Centre.

Mahzan, Ahmad Ayob. 1992. Kaedah Penyelidikan Sosio - ekonomi. Dewan Bahasa dan Pustaka.

Malaysia. 1976. Third Malaysia Plan 1976 - 1980. Government Printer; Kuala Lumpur.

Malaysia. 1981. Fourth Malaysia Plan 1981 - 1985. Government Printer; Kuala Lumpur.

Malaysia. 1986. Fifth Malaysia Plan 1986 - 1990. Government Printer; Kuala Lumpur.

Malaysia. 1991. Sixth Malaysia Plan 1991 -1995. Government Printer; Kuala Lumpur.

Malaysia. 1991. Preliminary Count Report: Population and Housing Census of Malaysia. Department of Statistics Malaysia, Kuala Lumpur.

Malaysia. 1996. Seventh Malaysia Plan 1996 - 2000. Government Printer; Kuala Lumpur.

Malaysia. 2001. Eighth Malaysia Plan 2001 -2005. Government Printer; Kuala Lumpur.

Marbeck, A.B. 1997. Legal and Administrative Framework for Housing: The Private Sector Viewpoint. In Housing The Nation. CAGAMAS BERHAD.

McClave, James $\mathrm{T}$ and Terry Sincich. 2006. Statistics. Pearson Education International

Monk, S. 1991. Land Supply and Housing. Housing Studies. Vol.11

Murie, Alan. 1976. Housing Policy and the Planning System. London, Allen and Unwin

Nachmias, David. 1996. Research Methods in the Social Sciences. Arnold 
Ozay, Mehmet. 1988. Development in Malaysia: Poverty, Wealth and Trusteeship. Ihsan, Kuala Lumpur

Ratcliffe, John. 1974. An Introduction to Town and Country Planning. Hutchinson of London

Roslan Ismail. 2002. Notes for Courses of The Malaysian Institute of Planners, INSTUN (unpublished document).

Simon Guy and John Henneberry Eds. 2002. Development and Developers: Perspectives on Property. Real Estates Issues, Blackwell Publishing.

Spiegel. 1976. Statistic. Schaum Series 


\title{
SUSTAINABLE CITY PLANNING: EMPHASIS ON THE MANAGEMENT OF ENVIRONMENTALLY SENSITIVE AREAS ${ }^{1}$
}

\author{
Halimaton Saadiah Hashim ${ }^{2}$, \\ Joy Jacqueline Pereira \& Ibrahim Komoo \\ Institute for Environment and Development (LESTARI) \\ UNIVERSITY KEBANGSAAN MALAYSIA
}

\section{Abstract}

The need to identify and manage environmentally sensitive areas (ESAs) is of fundamental importance for seeking balanced development within and around such areas based on the concept of sustainable development. The identification of ESAs enhances the understanding of the various trade-offs between land development, environmental protection and societal well-being, and this facilitates effective planning for future development. The concept of ESAs, which evolved from a sectoral approach at the international and national levels, was modified to be more integrated for its implementation at the city and state levels, even at national levels. The Selangor State Policy on ESA was officially launched on 5 June 1999. The Policy takes into account the importance of an area from the perspective of the implementing government agencies and the perspective of its major function in terms of providing life support systems, heritage value as well as risks associated with hazards. Integrated ESAs defines an area containing various ecosystems that play an important role in ensuring the well being of the environment as well as society which could be threatened by development. Three groups of ESAs are identified. These are ESA of Heritage Value, ESA associated with Hazards and ESA that is important for Life Support Systems. ESA of Heritage Value is defined as an area that has historical, cultural or scientific value. ESA associated with Hazards is defined as areas that are associated with high risks of natural or man-made hazards. ESA for Life Support Systems takes into account the present and future needs of society to ensure adequate quality of life based on resources available in the State. Integrated ESAs are useful to ensure land use that supports the aspirations of sustainable development and has the potential to enhance stakeholder participation, particularly when used in conjunction with existing land use planning mechanisms. Notwithstanding this, there are many challenges facing its application on a routine basis. These include lack of awareness and capacity, which needs to be urgently

\footnotetext{
' This paper was presented at the $20^{\text {th }}$ EAROPH World Congress and Mayors' Caucus, "Sustainable Human Settlements For A Better Quality of Life", 14-15 August 2006, Miri, Sarawak, Malaysia.

2 Datin Paduka Dr. Halimaton is a Principal Research Fellow at Institute for Environment and Development, UKM. She can be contact at halima@pkrisc.cc.ukm.my
} 
Critical Area concept has yet to be implemented officially, its effectiveness cannot be assessed.

The Department of Environment has also specified guidelines for ESAs in Malaysia to assist in the assessment of development projects (DOE 1993). The DOE defines ESAs as areas that require special attention prior to the approval of development in that particular and adjacent site. This is to ensure that the scientific, economic and aesthetic values of such a site are not threatened and that the quality of life in the present and the future is not compromised. The concept of ESAs as advocated by the DOE in principle fulfills the needs of environmental protection in the implementation of sustainable development. However, the extent of areas identified is wide and yet the number of items specified is limited. As a result, the list of ESAs as documented in the guideline is difficult to be utilised for operationalising sustainable development through existing planning and management mechanisms.

The Town and Country Planning Department of Peninsular Malaysia approaches ESAs through the land use planning perspective. A consensus was reached at the national level in 1998 regarding the scope of ESAs that is relevant to Malaysia. Ten categories of ESAs were identified and these are for Biological Diversity, Highlands and Steep Slopes, Catchment Areas, Wildlife Protection, Rivers, Wetland, Coastal Margins, Permanent Forest Reserves, Geological and Landscape Heritage and Cultural and Architectural Heritage (JPBD 1998). The Department has since prepared generic guidelines for the management of sectoral ESAs with a widened scope and recommended a consultation process to be used by State and Local Authorities in the identification and prioritization of ESAs (JPBD 2004).

\section{PERSPECTIVES ON ESAS IN THE STATE OF SELANGOR, PENINSULAR MALAYSIA}

\section{The Sectoral ESA}

In 1998, the State Government of Selangor with the support and consensus of the various technical departments attempted to harmonise various concepts and definitions relating to ESAs, which could be implemented in line with the requirements of sustainable development. The State endorsed the ten basic categories of ESAS as identified at the national level for land use planning i.e. for Biological Diversity, Highlands and Steep Slopes, Catchment Areas, Wildlife Protection, Rivers, Wetland, Coastal Margins, Permanent Forest Reserves, Geological and Landscape Heritage and Cultural and Architectural 
Heritage. In addition, it was recommended that the scope of ESAs be enlarged to incorporate aspects such as existing mining and quarrying areas, ex-mining areas, areas with potential mineral resources, waste disposal sites, aquaculture, important marine resources and agriculture.

\section{The Integrated ESA}

The State Government of Selangor also recognised the need to resolve the issue of overlapping sectoral ESAs in order to ensure its practical implementation within the planning and management process. For instance, a portion of the forest for protection of steep slopes in a catchment area may also be gazetted as a reserve for wildlife. In such a case, that particular area may be classified under three different sectoral categories i.e. ESAs for Highlands and Steep Slope, ESAs for Catchment Areas and ESAs for Wildlife Protection. It was decided that this would be overcome by integrating the various sectoral ESA (see Figure 1)

As the scope of ESAs that is required by the State involves additional categories in which development activities are conducted, there was also a need to identify the degree of sensitivity within the ESAs. This would enable the setting of limits for development activities that could be allowed in any category of ESAs. This led to the development of the Integrated ESAs.

Based on the above and upon the vision of the State Government, the concept of Sectoral ESAs was broadened to the concept of Integrated ESAs, encompassing conservation, optimum resource use and societal well-being, to meet the needs of sustainable development. In widening the scope of sectoral ESAs several limitations were identified. These include the land use conflict between the various agencies which are entrusted to manage resources on a sectoral basis, the existence of policies and management objectives which do not mutually support the overall well-being of sectoral ESAs, and the existence of ESAs which do not come under the jurisdiction of any of the existing agencies. Thus, the success of establishing Integrated ESAs as a tool to operationalise sustainable development required the commitment, cooperation and continuous networking of various implementing agencies at the State and Federal levels. This was institutionalized through the Selangor ESA Policy. 


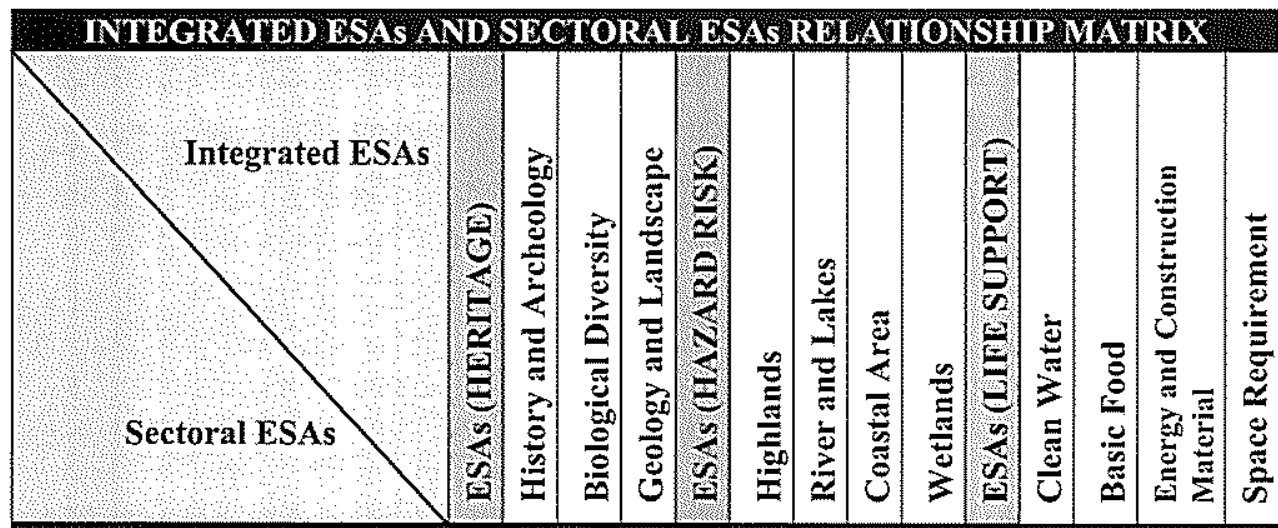

\section{FORESTRY}

Virgin Forest Reserve

Catchment Forest

Highland Forest

Swamp Forest

Other Permanent Forest

Reserve

\section{FISHERIES}

Freshwater Fisheries

Coastal Fisheries

\section{FARMING AND}

\section{ANIMAL HUSBANDRY}

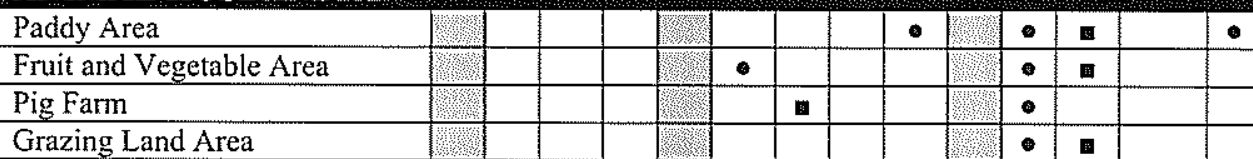

\section{WILDLIFE}

Wildlife Reserve

\section{COASTAL AREA \&}

RIVERS

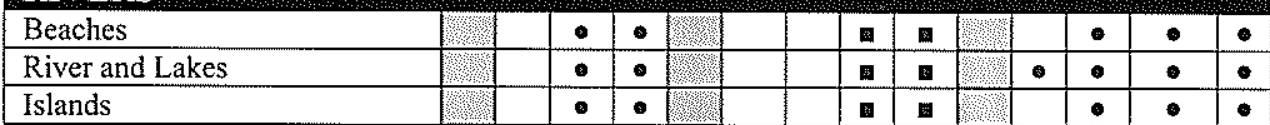

\section{MTNRAL AND ROCKS}

Sand and Pebbles

Rock Aggregates

Clay Materials and Soil

\section{WATER BODILS}

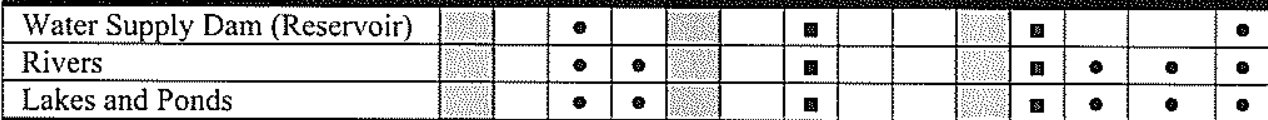

\section{HISTORY AND} ANTIQUITY 


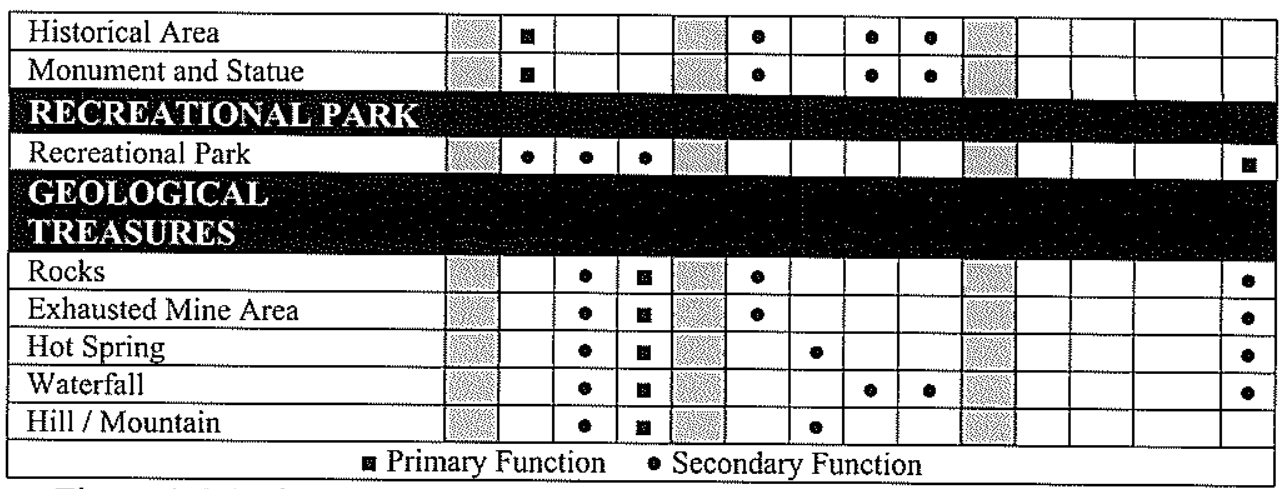

Figure 1: Matrix Depicting the Relationship of Integrated and Sectoral ESAs

\section{The Selangor ESA Policy}

The Selangor State Policy on ESAs was officially launched on 5 June 1999. The Policy takes into account the importance of an area from the perspective of the implementing government agencies and the perspective of its major function in terms of providing life support systems, heritage value as well as risks associated with hazards. The management of ESA incorporates the concept of conservation, optimisation of resource use and controlled development. The Selangor Integrated ESA concept provides a practical and effective land use planning tool to ensure environmental and societal well being.

Within the Integrated ESA framework, areas will be classified for controlled management, environmental conservation and as buffer zones. The implementation of the policy will be monitored by a Development Coordination Committee on ESAs that will define the types of development within the ESA. The State Government is presently in the process of preparing a detailed inventory of ESAs based on its degree of sensitivity. Upon completion of the inventory, an interim list of ESAs will be prepared for consultation and gazettment.

The State of Selangor would implement ESAs in two stages (GoS 1999, 2003). The first stage involves the implementation of Sectoral ESAs in the short-term. Each agency is to identify ESAs that are relevant to their sector, which could then be gazetted or managed, based on the degree of sensitivity, which would be determined. In the long-term, the State would develop and implement the concept of Integrated ESAs to resolve the overlapping sectoral ESA problem and accommodate the dynamic nature of ESAs, as a tool to operationalise sustainable development (see Figure 2). 
The ESA inventory is far from being in existence, although the target date is 2005. A start has been made with the highlands and slopes (JPBD 2005), but more needs to be done with other ESAs. The Selangor Town and Country Planning Department has a programme for this in 2006 but what is needed is for local authorities and other agencies to have their own inventories of ESAs and to gazette and enforce them. The Committee that has been established to monitor the implementation of the Selangor State Policy on ESAs is chaired by the State Secretary and its scope of work covers all types of ESA. Unfortunately all but two of the applications referred to the Committee are for development on highlands and slopes, the only other one being 'Sepang Gold Coast', which is on a coastal strip of sandy beach and mangrove swamp and a proposed development in an ex-mining lake. The approach taken by the Committee is still sectoral instead of integrated.

\section{The Elements}

Integrated ESA defines an area containing various ecosystems that play an important role in ensuring the well being of the environment as well as society, which could be threatened by development. This ESA consists of various elements and ecosystems involving various environmental functions as well as societal well being. The approach of categorising ESA should be in an integrated manner based on the perspective of sustainable development. Based on this approach, three groups of ESAs are identified. These are ESA of Heritage Value, ESA associated with Hazards and ESA that is important for Life Support Systems (GoS 1999; Ibrahim Komoo 1998). The evaluation of impacts of development in these areas should be within the framework of the natural heritage value, risk associated with various hazards and its value as a life support system. Using this approach, an ESA is categorised based on the perspective of its value and its function in the overall ecosystem.

ESA of Heritage Value is defined as an area that has historical, cultural or scientific value. Examples include historical or archaeological sites, areas with high biological and geological diversity, unique landscapes and sites of importance for education and research. Further subdivision of this ESA can be based on an assessment of its status as local, state, national or world-class heritage.

ESA Associated with Hazards is defined as areas that are associated with high risks of natural or man-made hazards. Examples include areas with problematic ground conditions for infrastructure development, areas that are prone to flooding, landslides, subsidence and erosions. A majority of these sites require 
careful planning and detailed site investigation to avoid the occurrence of human induced hazards. Included in this category are high risk areas associated with past development such as former industrial sites, mining areas and dumpsites that may be potentially hazardous to the community, should such areas be redeveloped.

Policy 1: The Selangor Darul Ehsan State Government will implement sectoral ESAs for the period of three to five years.

Policy 2: By 2005, the Selangor State Government will enforce management of integrated ESAs.

Policy 3: ESAs in Selangor are to be gazetted as areas of controlled development, buffer zones and areas for environmental conservation.

Policy 4: The Development Coordination Committee on ESAs is responsible for implementation of the Selangor Policy on ESAs.

Policy 5: The Development Coordination Committee on ESAs will decide on the type of development that can be allowed in ESAs.

Policy 6: The decision on the proposed plan for development in ESAs will be based on the Environmental Impact Assessment Report.

Policy 7: Existing laws that are relevant will be used as well as reviewed and strengthened from time to time.

Policy 8: The State Government machinery should be aware and appreciate the role of ESAs in ensuring the continuity of development in Selangor.

Policy 9: Educational and training programmes on ESAs and its management should be conducted for the public and private sectors as well as local communities.

Policy 10: The Selangor Geographic Information System (DEGIS) will contain details of ESAs and be networked to the standard database of all State and Federal agencies. 
Policy 11: The Selangor Information Technology Development Programme will take note of coordination and updating of the database at State and Federal levels.

Policy 12: The State Government will coordinate development plans for ESAs located at district borders, which come under the jurisdiction of more than one Local Authority.

Policy 13: The management of ESAs will be strengthened through research and development.

Policy 14: The State Government machinery has an appreciation for the role of ESAs in the context of life support systems, heritage conservation and risk of hazards.

Figure 2: The Selangor Policy on Environmentally Sensitive Areas (ESAs)

ESA for Life Support Systems ensures the present and future well being of society and other forms of life which is not given emphasis in many of the ESA concepts that have been promoted both at the national and international levels. ESA for Life Support Systems should be identified and classified so that the quality of life for the future generation is not compromised due to uncontrolled usage of the State's resources. Examples of areas that come under this category are sources of clean water, energy, building material, food production, settlements, parks and recreational areas. The classification of an area under this category is subjective and should be guided by existing state and national policies on development, settlement, agriculture, energy, water, natural resources and tourism.

\section{ESAS AND DEVELOPMENT}

\section{Development Principles in ESAS}

The Selangor Policy on ESAs is a very useful spatial planning tool that should be applied prior to or in conjunction with existing land use planning mechanisms at the State and local levels i.e. in the preparation or review of the State Structure Plan and Local Plans. A complete inventory of ESAs at the local level will be very useful for making decisions on applications for land use conversion or applications for planning permission, which are submitted 
routinely to State and Local Authorities. Such inventories should cover areas that are both within and around the ESAs for effective management.

Although the nature of ESAs may differ, decision making with regards to development therein should be based on three important principles. These are:

- All development in ESAs should be placed under the development category of Areas of Controlled Development;

- Development in ESAs shall not endanger the lives, result in loss of property or harm the health of local communities; and

- Development in ESAs should simultaneously enhance the socio-economic and environmental sustainability of that area.

The concept of Areas of Controlled Development is an administrative measure that was introduced in the structure plan of several districts in Selangor. In this concept, an area is divided into three main zones based on its physical and environmental characteristics as well as the types of development allowed therein. These are the restricted development zones, buffer zones and conservation zones. Development activities in these zones are administratively controlled. Such a measure can also be applied to control development in areas designated as environmentally sensitive.

\section{ESAs Inventory}

The preparation of a detailed inventory of ESAs requires information on its degree of sensitivity. Based on the Integrated ESA framework, an area can be classified into either one or more of the three categories, depending on the function it performs. Areas that are classified into two or three categories are very critical and tend to have a high degree of sensitivity towards development. Such areas are easily identified and are normally already earmarked or gazetted for conservation. For example, a catchment area located in the highlands has a life support function and also possesses a high risk for hazards, and would therefore be highly sensitive to development activities. Similarly, a forest in the highlands, which contains a variety of wildlife and plants and serves as a catchment area, is highly sensitive to development because it has a heritage value, provides a life support function and has a high risk of hazards.

All Sectoral ESAs can be reevaluated from the integrated perspective. Although an ESA may have more than one function in the integrated framework, not all these functions will have a high degree of sensitivity as illustrated in the example above. For each Sectoral ESA that is assessed, the degree of sensitivity for the functions in the integrated framework will vary. For example, a padi field would have a high degree of sensitivity with respect to its life support 
function but a low degree of sensitivity for its role as heritage value and hazards. The degree of sensitivity has to be established for each of the Sectoral ESA before it can be classified into the framework of an Integrated ESA.

\section{ESAs in Development Plans}

Development plans assist in the translation of socio-economic objectives into spatial and physical forms. The Town and Country Planning Act 1976 (Act 172) provides the legal basis for the formulation of development plans in Peninsular Malaysia. Such development plans include the National Physical Plan, State Structure Plan, Local Plan and Special Area Plan. In terms of hierarchy, the National Physical Plan is the most macro while the Special Area Plan is relatively micro.

The management of ESAs should be integrated into the process of formulating such development plans so that environmental aspects are considered in a more integrated manner. ESAs should be identified and mapped at scales that are appropriate for the various development plans. Whenever possible, the ranking and consultation process in identifying the ESA should be conducted within the process of developing or reviewing such plans. The integration of management of ESAs into development plans will at least ensure that the plans are legal although the ESAs are not gazetted as such. Strategic Environmental Assessment (SEA) and Sustainability Assessment (SA) are useful tools for assessing the sustainability of development plans at the macro level. Such tools should also be used to assess the effectiveness in managing ESAs with respect to sustainable development.

\section{ESAs and Planning Permission}

The Planning Permission process ensures that all development projects are conducted as stipulated in the development plans and other guidelines. In order to ensure that ESAs are managed effectively, reference to and consideration of ESAs should be made mandatory in the Planning Permission process. There must be mandatory requirements for references to be made on ESAs in the Development Proposal Report, which are submitted together with applications for planning permission. All development activities within or around an ESA should require an assessment similar to Environmental Impact Assessment (EIA). Detailed Environmental Impact Assessment should be mandatory if the proposed development is in an ESA and a preliminary EIA should be mandatory if the proposed development is next to an ESA. The ESAs Technical Development Committee chaired by the State Secretary vets through and advises the State Government and local planning authorities when considering 
applications for development approvals whether under the Town and Country Planning Act 1976 or the National Land Code 1965.

\section{FUTURE CHALLENGES}

Integrated ESAs is a very useful tool to ensure land use that supports the aspirations of sustainable development, particularly when used in conjunction with existing land use planning mechanisms at the State or local levels. The identification and prioritisation of ESAs at the State and local levels is important and will contribute greatly to the development of an effective National Spatial Plan. Thus, the challenge is to convince decision-makers that the availability of a complete inventory of Integrated ESAs both within and around the ESAs at the local level will be very useful for making decisions on applications for land use conversion as well as for applications for planning permission, which are submitted routinely to State and Local Authorities. In addition, sectoral resource managers also need to be convinced of the need for ESA identification to be done on a routine basis. They need to develop a systematic inventory of the resources that they manage, which is ranked by order of importance at the Federal and State levels. This information will contribute greatly to the development and review of structure and local plans at the State and Local Authority level.

In this context it is important to increase awareness and understanding as well as appreciation of the importance of having a full inventory of ESAs as well as conservation or controlled development of the ESAs by everybody, from planners and administrators to policy and decision makers at both state and local levels. It is also very important that local authorities are aware that they are the principal agencies to implement the policy for sustainable management of ESAs. For this purpose, local authorities should undertake a full inventory and gazettement of ESAs.

Integrated ESAs also has the potential to contribute to harmonisation of Federal-State issues with respect to management of land and natural resources. Making the consultation process in the identification of ESAs an explicit process, through open broad based participation of relevant stakeholders, preferably anchored by Local Authorities, and is critical in this context. It is important to ensure that the consultation process is not subsumed as part of the scientific exercise or information collection process during identification and ranking of ESAs based on degrees of sensitivity. Much work needs to be done to develop an effective consultation process, which takes into account elements 
such as conflict resolution, Delphi technique as well as economic tools such as benefit-cost analysis and willingness to pay.

Integrated ESAs can also serve as indicators of sustainable development. Its integrated nature allows it to represent many aspects of land and natural resource sustainability. This is important at the international level, when reporting progress towards sustainability to the United Nations or other Multilateral Environmental Agreements to which Malaysia is a signatory. The acreage of ESAs in any Local Authority or State also has the potential to serve as the basis for computing economic compensation, in balancing trade-offs between environment and development, between states and local authorities. These are aspects that need to be investigated in the future. Thus, there is much need for education and awareness building regarding ESAs and its current and future application in ensuring sustainable development.

The evaluation of ESAs has to be based strictly on the main function of the area, and not from the perspective of the function and objectives of the implementing agency. To enable an equitable evaluation, it is critical that a broad consultation process be institutionalised throughout the process of identification, prioritization and gazettment of the ESAs. This should involve all stakeholder groups including resource managers from Federal, State and local levels of government, the local community, private sector, non-government organizations and the scientific community. The institutionalisation of such a consultation process will provide the platform for reconciliation of both the top-down and bottom-up approaches in negotiating trade-offs in the management of ESAs, particularly with respect to competing land use. A participatory approach in the identification of ESAs as well as in planning and management of ESAs not only contributes to fulfill the need for stakeholder consultation in the progress towards sustainability, it also has great potential to enable practical implementation of the concept of intra-generational and inter-generational equity.

\section{CONCLUDING REMARKS}

An integrated ESA defines an area containing various ecosystems that play an important role in ensuring the well being of the environment as well as society, which could be threatened by development. Three groups of ESAs are identified. These are ESA of Heritage Value, ESA associated with Hazards and ESA that is important for Life Support Systems. The evaluation of impacts of development in these areas should be within the framework of the natural heritage value, risk associated with various hazards and its value as a life 
support system. Using this approach, an. ESA is categorised based on the perspective of its value and its function in the overall ecosystem.

Integrated ESAs are useful to ensure land use that supports the aspirations of sustainable development and has the potential to enhance stakeholder participation, particularly when used in conjunction with existing land use planning mechanisms. Notwithstanding this, there are many challenges facing its application on a routine basis. These include lack of awareness and capacity, which need to be urgently addressed. More work is also required to develop complete inventory of Integrated ESAs both within and around the ESAs, particularly at the local level and for ranking of resources according to their importance. In addition, there is a need to develop an effective consultation process, to be an explicit part in developing Integrated ESA, to be anchored by Local Authorities and involving all relevant stakeholders.

Integrated ESAs allows for the best possible land use for a given area by taking into account environmental, resource base and socio-economic factors. It also facilitates allocation of land that provides the greatest long-term and equitable benefit in line with the broad objective of sustainable development.

\section{ACKNOWLEDGEMENTS}

The authors wish to thank the research team from Universiti Kebangsaan Malaysia for providing continuos support in the development of the ESA concept. The State Government of Selangor Darul Ehsan is acknowledged for funding the Projects on Strategies for Sustainable Development and Agenda 21 Selangor (1999-2002) and Planning Guidelines for Development in Highland ESAs of Selangor (2005), implemented by the Town and Country Planning Department of Selangor, with technical assistance from the Institute for Environment and Development (LESTARI), Universiti Kebangsaan Malaysia.

\section{REFERENCES}

DOE 1993. Buku Panduan Kawasan Sensitif Alam Sekitar. JAS Kementerian Sains, Teknologi dan Alam Sekitar, Malaysia.

EPU 1993. Malaysian National Conservation Strategy-Towards Sustainable Development. Vol. 3: Critical Areas. EPU Prime Minister's Department, Malaysia. 
Government of Selangor (GoS) 1999. Strategi Pembangunan Mampan dan Agenda 21 Selangor: Kawasan Sensitif Alam Sekitar. Institut Alam Sekitar dan Pembangunan (LESTARI), Bangi.

Government of Selangor (GoS) 2003. Agenda 21 Selangor-Selangor's Commitment to Sustainable Development. Town and Country Planning Department of Selangor, Shah Alam.

Hyams, E. 1952. Soil and civilization. Thames and Hudson, London.

Ibrahim Komoo 1998. Kawasan Sensitif Alam Sekitar Selangor. Dialog Kawasan Sensitif Alam Sekitar Negeri Selangor. 14 Mei 1998 JPBD Negeri Selangor, Shah Alam Selangor.

Jabatan Perancangan Bandar dan Desa (JPBD) 1998. Kawasan Sensitif Alam Sekitar [Environmentally Sensitive Areas]. Rumusan Bengkel KSAS JPBD-Semenanjung Malaysia, 22-23 April 1998, Kuala Lumpur.

Jabatan Perancangan Bandar dan Desa (JPBD) 2004. Guidelines for the Conservation and Development of Environmentally Sensitive Areas and Its Surroundings. Draft Final Report Prepared by PAG Consult Sdn. Bhd. for JPBD-Semenanjung Malaysia, Kuala Lumpur.

Jabatan Perancangan Bandar dan Desa Selangor Darul Ehsan (JPBD) 2005. Garispanduan Pembangunan KSAS Perbukitan dan Tanah Tinggi Selangor. Draft Final Report Prepared by Institute for Environment and Development (LESTARI), UKM for JPBD-Selangor, Shah Alam.

MAFF 1989. Environmentally Sensitive Areas: First Annual Report as required Under Section 18(8) of the Agriculture Act 198, Ministry of Agriculture, Fisheries and Food, London.

Watson W.D., Tully, J.K., Moser, E., Dee D.P., Bryant K. Schall R. and Allan H.A. 1995. Coal Resources in Environmentally Sensitive Lands under Federal Management. Open-File Report 95-631. US Geological Survey, USA. 


\title{
THE ENVIRONMENT COMPONENT IN SUSTAINABILITY ASSESSMENT AT THE LOCAL LEVEL PLAN ${ }^{1}$
}

\author{
Abdul Hadi Harman Shah ${ }^{2}$ \\ Centre of Social, Development and Environmental Studies \\ Faculty of Social Sciences and Humanities \\ UNIVERSITY KEBANGSAAN MALAYSIA \\ Shaharudin Idrus \& Abdul Samad Hadi \\ Institute for Environment and Development (LESTARI) \\ UNIVERSITY KEBANGSAAN MALAYSIA
}

\begin{abstract}
This article discusses the needs and a possible methodology for assessing the environmental sustainability of local plan. Taking local needs and data available into consideration, using Kuala Selangor District as a hypothetical example, the possibility is explored and visualised spatially. Institutional efforts at sustainability indicators development are also highlighted, beginning with questioning our goals and objectives for development and environmental sustainability to select meaningful indicators.
\end{abstract}

Keywords: Environment, Local Plan, Sustainability, Ecological Footprint

\section{INTRODUCTION}

How does one assess the potential impacts of ideas and hopes? Local plans are manifestations of ideas and hopes for better urban living. Today, more than 80 percent of Selangor's populations are currently in urban centers. It is within these urban areas that high proportions of resources including energy are consumed directly by households, and industries for the manufacturing of goods, and waste generation and gas emissions are concentrated. These urban places are the centers of command and control appropriate to their level over

\footnotetext{
1 The earlier version of this paper has been presented at "Bengkel Pengenalan dan Kefahaman Penilaian Kelestarian Dalam Penyediaan Kajian Rancangan Tempatan" organised by Bahagian Rancangan Pembangunan, Pejabat Projek Kuala Lumpur, JPBD Semenanjung Malaysia at Sunway Logoon Resort, Bandar Sunway, Selangor on $4^{\text {th }}$ and $5^{\text {th }}$ October 2004.

${ }^{2} \mathrm{He}$ can be contact at aharmans@pkrisc.cc.ukm.my.
} 
their respective hinterlands. National and state urban policies and plans, official rules and regulations on land development; including buildings, normally have a central cole in any national strategy which promotes sustainable development. Cities and municipal councils are themselves important in that strategy. In the context of the present task it is highly appropriate to assess on what was useful and what was not, what was appropriate and what was less appropriate and so on concerning models and forecasts embodied in all the available plans, in particular the local plans, the subject of this scrutiny.

\section{SUSTAINABILITY SCIENCE AND SUSTAINABILITY GOVERNANCE}

Simply put sustainability science concerns with the scientific studies of sustainable development. Embedded in the term are studies on the various sectors with respect to the environment and the development. Both the physical environment and the human components involving the social, cultural and economic aspects, together with the inter-relation between man and the environment need to be systematically investigated in the context of sustainable development. The scientific studies yield knowledge about the integrity, vulnerability and resilience of both the physical and human components of the environment. Driving forces and the process of economic development, the process of environmental change in the face of socio-economic development, and the impacts of that change are also of major concern. With new understanding and knowledge about the man and environment relationship we can derive indicators and tools for sustainability assessment.

The scientific studies and tools above will not produce the conditions for sustainable development without better efforts at administering the knowledge and tools. At this juncture the scientific study of governance is important to find the best ways to get all sections of society involved in the process of achieving sustainable development. Sustainability governance involves all the institutions - such as government agencies and stakeholders; tools such as regulations, standards, and the entire process in decision making. Central to all these is the achievement of the core shared value that is sustainable development.

\section{Sustainable Development and the 'Environment' Component}

For more than two decades the term 'sustainable development' has been the buzzword worldwide. It is useful to add that the term has attracted too numerous a definition and has set debates to grasp its true meaning. The most widely quoted definition goes: 
'We must meet the needs of the present generation without compromising the ability of future generations to meet their own needs' (WCED, 1987)

The Selangor Sustainable Development Strategy, "Strategi Pembangunan Mampan Selangor" (2000) also adopted this definition, but, of course, with elaborations appropriate to the conditions and development goals of Selangor. More importantly, the term has two main ideas about the management of human activities; one centers on development goals, the other on limiting the harmful impacts of human activities on the environment. The concern for both development and environment has a long history but the question on how the relationship between the two should be articulated is recent. For Malaysia, development goals are a priority, that by 2020 the country would have developed from third world to first. While working towards realizing development goals, the environment should remain in good form, with negative impacts of human actions well in control.

\section{'Environment' Component in Sustainable Development}

When viewing development and environment together, there seems to be some uncertainty as to what is to be sustained. First, is it ecological, socio-cultural or economic that has to be 'sustainable'? Second, shall we focus on national, regional, and local projects or cities?

For the present purpose, the discussion is about the 'environmental component' at the scale of the local plan. Since the concern is more on the environment, for a long while the term 'sustainable' has been widely used in relation to ecological sustainability. In the ecological sustainability the main focus is on natural resources used either in specific projects or the wider programmes of human activities. The assumption is that economic development is necessary to create wealth for socio-economic development and hence improving the citizen's quality of life. Natural resources are necessary to economic development but there are limits to their supply. In this sense development should proceed but always at a rate that can assure sustainable use of resources. Uncontrolled use of resources may result in environmental degradation, resulting in the following:

- Reduction in the quantity and quality of resources available for further consumption and production.

- Overuse of the waste-absorbing capacity of the environment.

- Loss in biodiversity. 
- Declining environmental resilience resulting in increased incidence of hazards.

- Increasing pressure on land for future built-up environment.

In the process of development activities that are seen to be sustainable, this ecological component should meet the following characteristics, namely;

- The activities do not damage natural resources overtly.

- The overall effects of development have negative effects on certain resources but carry positive impacts on others.

Components of sustainable development has been disaggregated (Hardoy, Mitlin and Satterthwaite, 1992:181) into the following: - sustainable use of renewable resources (such as fresh waters, aquifers, soil, biomass); maintaining within absorptive capacity of local and global sinks for waste (such as for greenhouse gases, ozone depleting, chemicals, surface run-off keeping within BOD of water bodies); minimizing use of non-renewal resources (fossil fuels, minerals and loss of biodiversity); and meeting human needs involving access to natural resources, access to adequate healthy environment and basic services.

The scope allows for a search of assessment indicators that have some commonalities across larger areas and specific indicators that are unique to the local scene.

\section{SUSTAINABILITY ASSESSMENT: ENVIRONMENTAL SUSTAINABILITY}

Sustainability assessment is essential to ensure that all efforts towards achieving the shared value of sustainable development are on course. Since 'development' entails the interactions of many sectors, we need to pay attention to the impacting sectors that range from institutions and their policies on development to the developers themselves. The impacts on the environment are varied, some more noticeable than others.

\section{Environmental Assessment of Development Plans}

There is an increasing body of literature examining environmental assessment of development plans lately. This environmental assessment of development should be distinguished from that of an EIA (Environmental Impact Assessment). One group of study asserts that such an assessment is commonly 
referred to as 'strategic environmental appraisal' (Tyldesley and Associates, 2003). The group maintains that the assessment is a process of identifying and assessing the effects of a development plan on the environment. The group suggests that assessment may be taken into account before a development plan is approved. However, it is interesting to note that in making the assessment, the plan's objectives, policies and proposals must be seen in relation to the larger environmental objectives of the country. It also identifies possible impacts. This is done through constant assessment and adjustment such that the plan will produce minimal impacts on the environment.

\section{Assessing the Environmental Sustainability Assessment of a Local Plan}

In the context of the current discussion the assessment is different from the more established Environmental Impact Assessment (EIA) that is normally carried out for certain size projects before the actual project is carried out. The assessment is made on the existing state of the environment before project development. Although there has been request for continual monitoring and post-project assessment, the EIA is basically about the current conditions of the environment and it is a reaction to a specific development proposal.

The environmental aspect of sustainability assessment of a local plan is a process. It goes through the cycle of plan preparation, implementation, monitoring and review. If a local plan is already available the assessment of the environment should follow through the cycle. It is able to deal with wider considerations such as providing some strategic locational problems. It helps to unravel cumulative impacts of several development proposals especially those that are too small for any EIA. In short, the sustainability assessment of the environment in a local plan can assess overall environmental impacts of implementing a plan.

\section{Potential Benefits of Assessing Environmental Sustainability of Local Plans}

There are potential benefits in doing the assessment. Among them is the clarification of environmental aims and objectives of the local plan, and to see if there is any conflict between the local plan environmental objectives and the wider environmental objectives of the planning authority. Sustainability assessment also allows the local government to look into consequences of policies and development proposals on the environment, looking at all possible measures to minimize or prevent the impacts of development on the environment and guiding development activities to be in line with the environmental aims of sustainable development. 


\section{DERIVING A METHODOLOGY FOR SUSTAINABILITY ASSESSMENT}

While the structure plan is a strategic planning document to present, conceptually, long term development strategies, the local plan is where these ideas are made site-specific, even to the land parcels level. While the structure plan presents broad policies and a general demarcation, it is at the local plan that these ideas are made more concrete. Assessing sustainability at the local plan level, thus, is not merely the evaluation of the current environment; it is also an evaluation of on-going planning efforts at sustaining the environment, and the continued drive towards sustainable development.
What do we assess?

1. Assessing the environment

a. Assessing the characteristics of the environment

i. Vulnerability

ii. Resilience

b. Assessing the quality of the environment

2. Assessing the local plan

a. Impacts of planned change

3. Assessing projects

a. Assessing feasibility

b. Assessing effectiveness

Figure 1: What do we assess?

There are several aspects of sustainable assessment necessary at the local plan level. The first is an assessment of environmental characteristics which should be used to determine the vulnerability and resilience of the local environment. Next an assessment of impacts from the changes proposed in the local plan should be done. Only when both assessments are completed can one assess the current and future quality of the environment, signifying its level of sustainability and livability.

Aside from the planning level, local plans are referenced for any development projects proposed. Environmental sustainability assessment of these projects can assist in determining the contribution or hindrance that the project would have on the continued sustainability of the environment. Assessment of environmental feasibility and effectiveness are often part of the exercise

\section{Methods of Assessment}

Assessment is an exercise in detailed reasoning. To assess fairly one needs

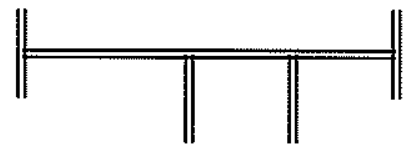

Descriptive Analytic Evaluative Optative

Figure 2: Assessment within the environmental analysis continuum 
to realise that any assessment is value-laden. The important part is to ensure that the values be made explicit. Defining goals and objectives is part of the explication process. To ensure that the assessment process is relevant to the local experience, the values that the goals and objectives are meant to represent must be made clear. To simply transplant global goals without a local context would make the goals meaningless. The local context can be set in the constraints to be identified next. These are local conditions that set realizable targets to goals and objectives. Local conditions often require an inventory of the environment as well as changes expected. Interventions either in terms of development plans, new industries or infrastructures are then evaluated, focusing on their impacts. These impacts are then converted to indicators of sustainability, standardized and presented for decision taking.

Some examples of common tools for sustainability assessment include:

1. Ecological footprint

2. Environmental Sustainability Index

3. Wellbeing Index

4. Environmental Pressure Index

\section{Ecological footprint}

A favorite tool in assessing environmental sustainability is the ecological footprint analysis. Ecological Footprint (EF) is an accounting tool to measure environmental impact through the calculation of area needed to support activities in a sustainable way. It 'estimates the resource consumption and waste assimilation requirements of a defined human population or economy in terms of corresponding productive land area (Wackernagel and Rees 1996).
1. Defining Goals and Objectives

2. Defining local constraints

3. Inventorying state of the environment

4. Identifying changes

5. Identifying interventions

6. Identifying impacts

7. Converting impacts into indicators of sustainability

8. Presenting sustainability

Figure 3: General Steps in Assessment

\section{Environmental Sustainability Index}

Environmental Sustainability Index (ESI) attempts to measure the progress towards sustainability of nations by using a variety of indicators, which represents the most important factors determining the sustainability (Global 
Leaders et al, 2002). ESI is an index that is achieved by aggregating 68 indicators, which are divided into five core components:

- Environmental Systems

- Reducing Stress

- Reducing Human Vulnerability

- Social and Institutional Capacity

- Global Stewardship

\section{Wellbeing Index of nations}

Wellbeing index (WI) is a sustainability assessment method for human communities in global, national or local level. It considers human society and nature as equal systems, and gives them equal weight. The icon, Egg of Wellbeing, is used to illustrate sustainability where white is being the ecosystem that surrounds the humans symbolised with the yolk (Prescott-Allen, 2001).

While these tools are commonly used to assess sustainability, they require data collection and management that are not usually available to the local authorities. With efforts and commitments all local authorities can develop their own environmental footprint and indices of sustainability mentioned. One can even develop a sustainability analysis of the structure and local plans but perhaps a more customised or preliminary assessment given current conditions is more pertinent at the beginning of the assessment exercise.

\section{LESTARI'S EFFORTS AT SUSTAINABILITY INDICATOR DEVELOPMENT}

At the local scene, the Institute for Environment and Development (LESTARI) at Universiti Kebangsaan Malaysia (UKM) has been active in the development as well as the construction of sustainability indicators. Focusing on indicators for developing countries, several of the studies pointed towards a methodology for appropriate sustainability indicators. Peterson, P.J. et al. (1997a) began the effort with indicators at the national level, linking these indicators to those available globally. LESTARI then moved to look at indicators for urban and the industries. Today LESTARI is embarking on yet another stream of need; assessment of sustainability at the local level, and linking that to the need of development plans, especially at the local plan level. Yet all with one purpose the development of a better understanding of sustainability. A few studies have been carried out at Institute for Environment and Development (LESTARI), 
Universiti Kebangsaan Malaysia (UKM) regarding the sustainability indicator development especially in Malaysia. The discussion of the sustainability indicators development touching on concept of indicators and application to the various levels of government agencies (see Peterson, P.J. 1997a; Peterson P.J. 1997b; Nordin M. 1999; Nordin M. 20001a; Nordin M. 20001b; Peterson P.J. 2000a; Peterson P.J. 2000b; Peterson P.J. 2002a; Peterson P.J. 2002b; Peterson P.J. \& Granados 2002; Peterson P.J., Sham Sani \& Nordin, M. 1999; Peterson, P.J., Ahmad Fariz Mohamed \& Mazlin Mokhtar 2003; Sham Sani 2001; A. Latiff et. al. 2004)

\section{Proposed Components of Local Environmental Sustainability Assessment: Compliance, Balance and Goals Achievement}

There are many ways to assess environmental sustainability at the local plan level. All of them require some assumptions. The method proposed in this section is based on several considerations:

- That the local authorities already have a vision of the environmental sustainability to be found in their structure plans and detailed in the local plans. Compliance with the structure and local plans are argued to be in line with promoting environmental sustainability. The question lies in the translation of compliance into sustainability indicators.

- That the local community can define environmental sustainability goals.

- That balance between user and producer, as well as between sectors are important in determining environmental sustainability.

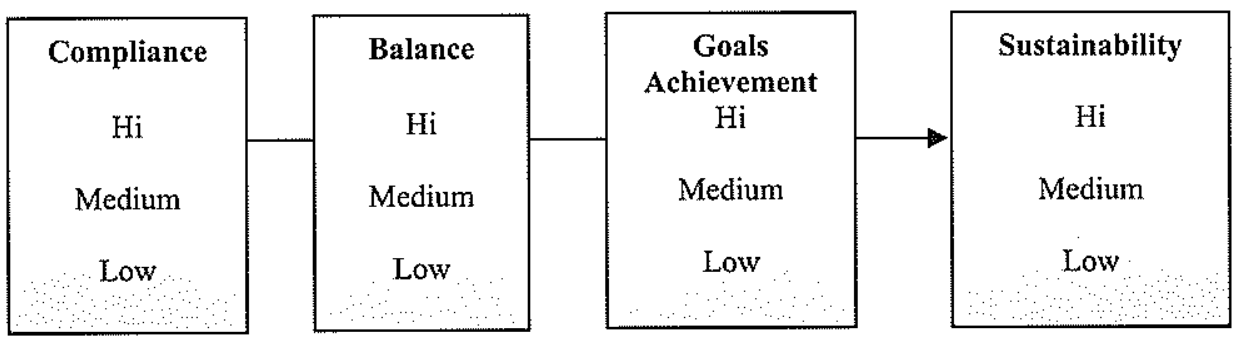

Figure 4: The components of local ESA.

\section{Approach}

The approach combines three common evaluation tools in planning; the checklist method, the goal achievement matrix and the planning balance sheet approach. 


\section{Steps:}

1. Develop a checklist based on environmental related items in the local plan. Determine the extent of compliance to the checklist (Table 1). Begin by determining generally high, medium or low level of compliance. Less than $30 \%$ compliance would be considered low while compliance within $30 \%-70 \%$ is considered medium compliance. Anything more than $70 \%$ would then be considered high. This is of course a simple demarcation to begin the analysis. The checklist method allows one to assess the environment and development activities with respect to predetermined goals and visions.

2. The second part of the analysis requires a re-look at the various environmental, socio-economic and institutional initiatives or policies and to assess them with respect to a few environmental sustainability goals (Table 1). The idea is to determine the extent to which each initiative has achieved the goals set. The local government needs to come together to determine the goals and measures of achievement. For the beginning, the common sectoral objectives for water, air, biodiversity and vector borne diseases can be used to assess achievement.

3. The third step is to place these initiatives as well as samples of specific projects in terms of environmental costs and benefits. The costs and benefits need not necessarily be set within a Ringgit function but to assess equity, producers and users are best determined and separately assessed.

4. The fourth step is to develop a synthesis matrix based on the three previous analyses and present the findings spatially. 
Environmental sustainability of Kuala Selangor: An example in method

Table 1: Environmental Goals Achievement Matrix

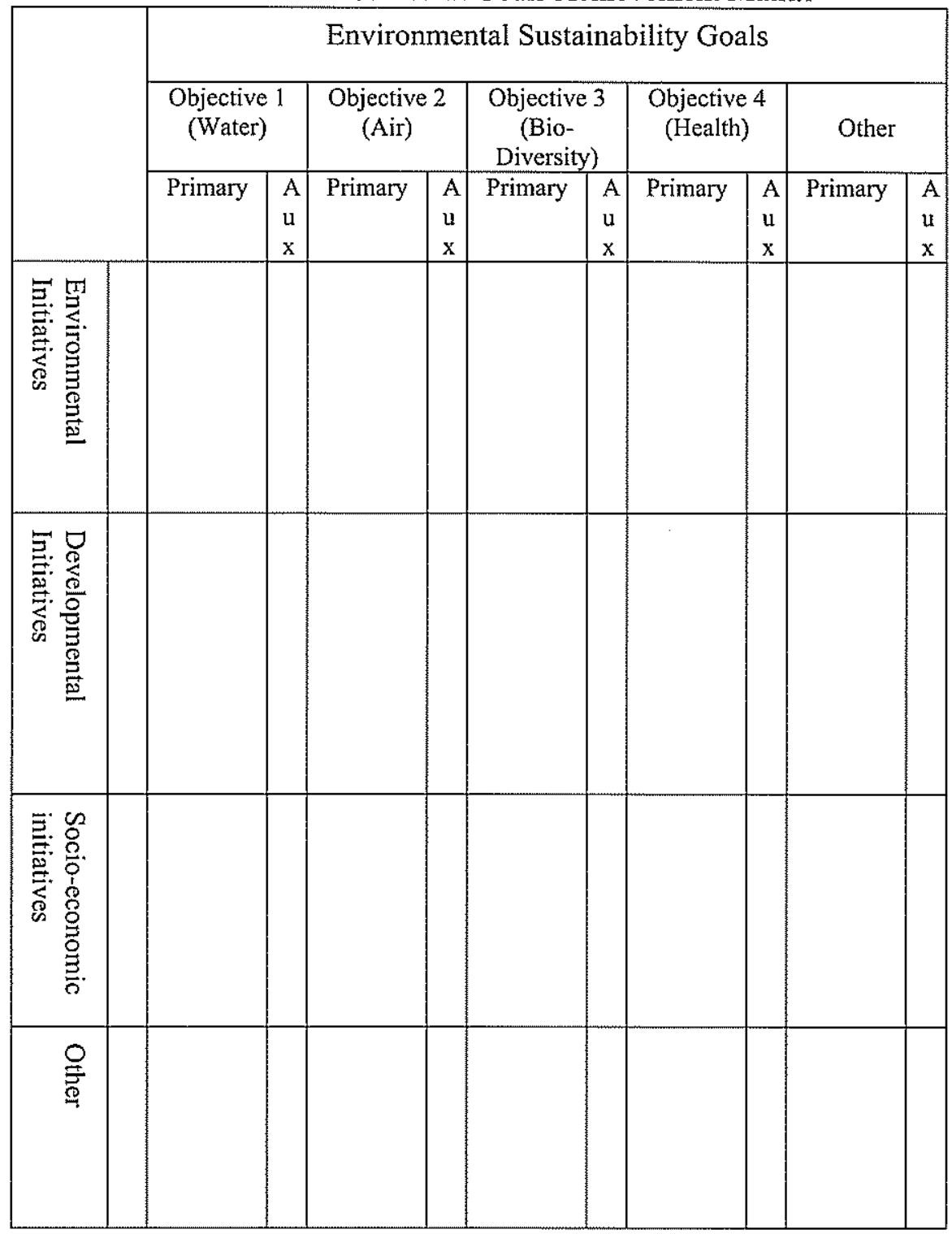


Table 2: Environmental Sustainability Balance Sheet

\begin{tabular}{|c|c|c|c|c|c|c|c|c|}
\hline \multicolumn{2}{|c|}{} & \multicolumn{9}{c|}{ Cost of Initiative } \\
\hline & $\begin{array}{c}\text { Environmental } \\
\text { Costs }\end{array}$ & \multicolumn{2}{|c|}{ Economic Costs } & \multicolumn{2}{|c|}{ Social Costs } & \multicolumn{2}{|c|}{$\begin{array}{c}\text { Direct Mgmt } \\
\text { Costs }\end{array}$} \\
\hline & Producer & User & Producer & User & Producer & User & Producer & User \\
\hline & & & & & & & & \\
\hline \\
\hline
\end{tabular}


Table 3: Compliance Checklist

\begin{tabular}{|l|l|l|l|l|l|}
\hline \multirow{2}{*}{$\begin{array}{l}\text { Environmental } \\
\text { elements }\end{array}$} & \multicolumn{5}{|c|}{ Compliance Zones } \\
\cline { 2 - 6 } & Housing & Commercial & Industrial & Institutional & $\begin{array}{c}\text { Open } \\
\text { space } \\
\text { and } \\
\text { Access }\end{array}$ \\
\hline Water & & & & & \\
\hline Air & & & & & \\
\hline Noise & & & & & \\
\hline Soil & & & & & \\
\hline Topography & & & & & \\
\hline Slope & & & & & \\
\hline Etc. & & & & & \\
\hline
\end{tabular}

\section{A Truncated Spatial Example}

A hypothetical example of the method, using Kuala Selangor as the case in point, is presented to show possible implementation of the approach. Kuala Selangor's need to maintain the sustainability and richness of its natural environment, both for the ecosystem and economic reasons provides a good example of complementary economic and environmental goals, as well as the need to assess the environment in a more integrated manner.

Matching two elements from Table 1; the development initiative in terms of desired population density, derived from proposed housing density requirements of the local plan, and an emergent environmental element of vulnerability (in this case using the Selangor Environmentally Sensitive Area Classification (KSAS) presents a partial assessment of the local plan. A simple overlay exercise provides a preliminary (level 1 ) view of where the local plan impacts would be least sustainable, environmentally. Further overlays with other initiative dimensions, as well as detailing specific environmental goals will 
further provide a more integrated assessment of the local plan. Adding weights to the different goals will further fine-tune the assessment model.

Figure 5 summarizes the results of the spatial distribution of environmental vulnerability of Kuala Selangor derived from the matrix in Table 1.

Environmental Vulnerability: Kuala Selangor

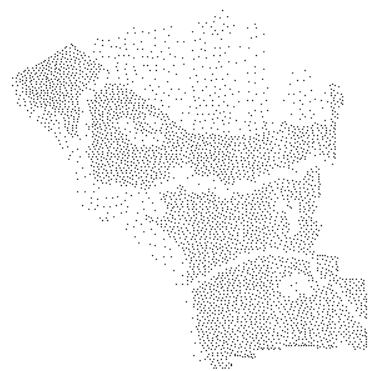

Levels of Env. Vulnerability Low Vulnerability Medium Vulnerabillty High Vulnerabillty
Population Density: Kuala Selangor

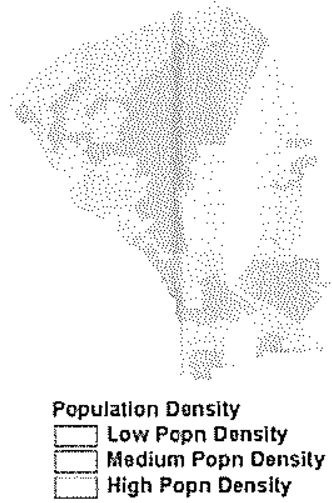

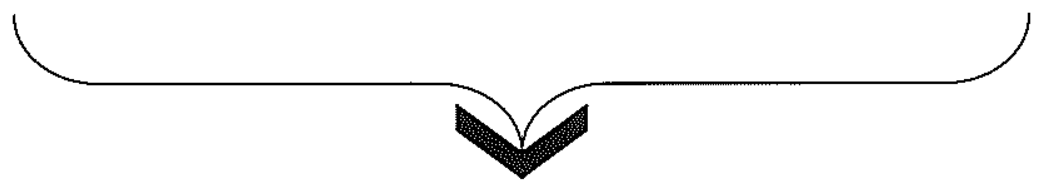

Low Environmental Sustain ability Areas

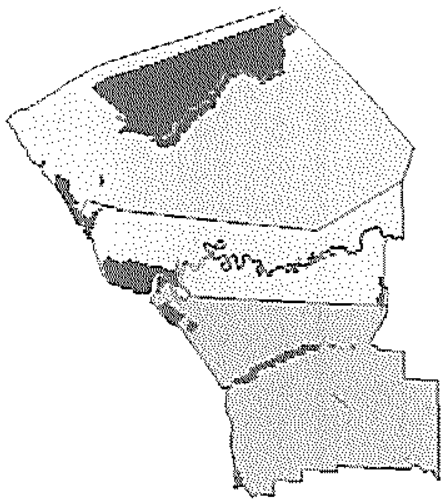

Sustalnablity Level

Ex] Low Sustainability

Developame zone

7 Tourism Developaent Area

Tourism Developant arez

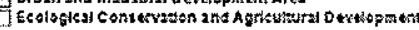

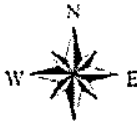

Figure 5: Environmental Vulnerability Index, Kuala Selangor, 2004. 


\section{CONCLUSIONS}

What we wish for in setting up this environmental sustainability assessment method is a better indication of where we are going as a community, given our goals and our base environment. Development plans are often multi-objective, and at times we might lose track of our targets. Part of the effort to develop a better quality of life and increasing the livability of our surroundings, is developing the understanding about the environmental livability of our lives and our dreams for the future. That is also the current global agenda on sustainable development. The problem is on the definition and boundaries of environmental sustainability. It would be easiest to simply pluck ready-made indicators of sustainability put forth by the United Nations and other bodies, made readily available through the net.

Or one can take the more difficult, but more meaningful task of thinking through our own sustainability indicators at the local level. Beginning with questioning our goals and objectives for development and environmental sustainability, we move to select indicators most meaningful in the local context. With these we re-examine our policies and plans, and in doing so we 
re-assess our relationship with our immediate and extended environments; redefining our relationship with our past and future.

\section{REFERENCES}

A. Latiff J.J. Pereira, A. Hezri Adnan, \& A.A. Aldrie. 2004. Indicators of Sustainable Development: Assessing Changes in Environmental Conditions. Bangi: LESTARI Publisher.

Global Leaders for Tomorrow World Economic Forum, Center for International Earth Science Information Network Columbia University (CIESIN), Yale Center for Environmental Law and Policy (YCELP) (2002) 2002 Environmental Sustainability Index. [Online]. Available: http://www.ciesin.org/indicators/ESI/ESI2002 21MAR02a.pdf [2003, October 3]

Hardoy, J.E., Mitlin. D. and Satterthwaite, D. 1992. Environmental Problems in Third World Cities. London: Earthscan Publications Ltd.

Lichfield, N. et al. 1975. Evaluation in the Planning Process. New York: Pergamon Press.

Nordin M. 1999. Potential Indicators for Inclusion as Sustainable Development Indicators (SDIs) for Malaysia. Bangi: LESTARI Publisher.

Nordin M. 20001a. Sustainable Development Indicators: Current Status and Future Challenges. In A. Latiff, J.J. Pereira, A.A. Hezri (Ed.). Penyelidikan Penunjuk Pembangunan Mampan di Universiti Kebangsaan Malaysia. Bangi: LESTARI Publisher.

Nordin M. 20001b. Indicators of Sustainable Development: the Malaysian Perspective. In J.J. Pereira \& I. Komoo (Eds) Geoindicators for Sustainable Development. Round Table Dialogue No.7. Bangi: LESTARI Publisher.

Peterson, P.J. 1997a. Indicators of Sustainable Development in Industrializing Countries. Vol. I. Management Response Strategies. Bangi: LESTARI Publisher.

Peterson, P.J. 1997b. Indicators of Sustainable Development in Industrializing Countries. Vol. II. From Concepts to Action. Bangi: LESTARI Publisher Peterson, P.J. 2000a. Indicators of Sustainable Development in Industrializing Countries. Vol. IV. Second Generation Indicators. Bangi: LESTARI Publisher

Peterson, P.J. 2000b. Indicators for Hazardous Waste Management: National Capacities and Capabilites. In Proceedings Pacific Basin Conference on Hazardous Waste, 10-14 April. Manila. 
Peterson, P.J. 2002a. Sustainable Development Indicators: Concept and Application. In Agenda 21 Selangor Round Table Dialogue: Sustainable

Development Indicators. 23 May. Putrajaya (CD Copy).

Peterson, P.J. 2002b. Performance Indicators for Hazard evaluation of Landfill

Sites. In Proceedings Second Asia-Pacific Landfill Symposium, 25-28 September. Seoul.

Peterson, P.J. \& Granados, A. 2002. Towards Sets of Hazardous Waste Indicators: Essential Tools for Modern Industrial Management. Environmental Science and Pollution Research 9, 204-214.

Peterson, P.J., Sham Sani \& Nordin, M. 1999. Indicators of Sustainable Development in Industrializing Countries. Vol.III. Key Indicators for Tropical Cities. Bangi: LESTARI Publisher.

Peterson, P.J., Ahmad Fariz Mohamed \& Mazlin Mokhtar 2003. Indicators of Sustainable Development in Industrializing Countries. Vol. V. Measuring Industrial Change in Malaysia: Linking Strategies with National Policies. Bangi: LESTARI Publisher.

Prescott-Allen, Robert (2001) The Wellbeing of Nations: A Country-by Country Index of Quality of Life and the Environment. Washington: Island Press

Selangor. 2000. Strategi Pembangunan Mampan Selangor. (Selangor Sustainable Development Strategy) Bangi: LESTARI Publisher.

Sham Sani 2001. Developing Urban Sustainability Indicators for Malaysia.

LESTARI Public Lecture Series.No. 3. Bangi: LESTARI Publisher.

Tyldesley, D. \& Associates. 2003. Environmental Assessment o Development Plans. Scottish Executive Social Research. Interim Planning Advice.

Wackernagel, M and Rees, W. 1996. Our Ecological Footprint: Reducing Human Impact on the Earth. Gabriola Island: New Society Publishers WCED 1987. Our Common Future. London: Oxford University Press. 


\title{
DEVELOPING A COMMUNICATIVE PLANNING APPROACH TO RESOLVE LAND USE CONFLICTS IN JELUTONG AREA OF GEORGETOWN, PENANG, MALAYSIA
}

\author{
Mohammad Abdul Mohit ${ }^{1}$ \\ Department of Urban and Regional Planning \\ Kulliyyah of Architecture and Environmental Design \\ INTERNATIONAL ISLAMIC UNIVERSITY MALAYSIA \\ Raja Mohd Firdous B. R.M. Harun \\ Department of Urban Planning \\ Pulau Pinang Municipal Council (MPPP) \\ Georgetown, Penang, MALAYSIA
}

\section{Abstract}

This paper examines the urban land use conflict cases which have generated several environmental problems in a small area of Jelutong in Georgetown, Malaysia. Three cases of land use conflicts were identified in the area. The first case was the location of two industries adjacent to a residential area; the second involved the location of a factory within a river reserve area; and the third case was the location of a bus workshop within surrounding residential land uses. The conflicts of interest and spatial/ environmental implications of each of the conflict cases were analyzed. Based on the findings, the paper also identifies the reasons for the occurrence of those conflicts. Five alternative approaches were developed, with a recommendation to adopt a communicative approach (consensus building) to deal with the environmental problems and improve the living environment of the area.

Keywords: Urban Land Use Conflict, Communicative Approach, Environmental Implications, Living Environment, Conflict Resolution

\section{INTRODUCTION}

Recently, many developing countries in Asia are experiencing a process of rapid urban growth which often leads to urban land use conflicts ${ }^{2}$ and provide

\footnotetext{
${ }^{1}$ Currently he is an Associate Professor. He can be contact at mamohit@ilu.edu.my.

${ }^{2}$ Refers to incompatible land uses due to involvement of multiple parties. Besides being a physical phenomenon, the concept has spatial /environmental implications. The
} 
greater challenges to the town planners in resolving these conflicts. Generally, a process ' f land use conflict occurs due to incompatibility of land uses, because the lan $\downarrow$ use game is rife with opportunities for conflict (Kaiser et.al. 1995:460) and when the market forces alone determine the land uses of a particular area (Roo and Miller, 2000).

The process of urbanization in Georgetown during the 1960s and 1970s was quite fast. As a result, many conflicting land uses developed in the city. In fact, the issue of land use conflicts has been mentioned in the Draft Structure Plan (Amendment) of MPPP 2000, in the following words:

"There are serious land use conflict cases within strategic areas of Georgetown. For instance, the Small and Medium Industry (SMI) in Jelutong is located adjacent to the residential area...Even though these issues had been identified in the Structure Plan of MPPP 1987, there are no specific actions being taken till today." (Draft Structure Plan (Amendment) of MPPP 2000, p.17-5)

Therefore, a study to examine the land use conflict cases in the Jelutong area of Georgetown is essential for the sustainable urban development of the city.

\section{THEORETICAL PERSPECTIVE}

Communicative planning was developed as an alternative for the rational comprehensive planning. The failure of the rational planning approach and the necessary role of communication in environmental planning plus new changes in societies have led planning theorists towards new approaches in which communicative planning has a major place (Asgary and Saki, 1995, p.1). This planning paradigm, with its emphasis on participation as a value, has its roots in the Habermas (1984) communication theory of society which states that interpersonal or mutual understanding through the communicative activities is a key factor to solving social problems. To increase such mutual understanding Habermas develops the ordinary, common sense communication of mutual understanding and consensus that makes any shared knowledge possible. The communication in this term is not only transmission of information but it contains several other important factors such as moral values. Habermas argues that planning requires the consent that grows from the process of collective

situation also involves clashes between value judgements relating to one or more mutually influential aspects or factors experienced as such by one or more parties (Roo, 2003, p.7). 
criticism, not from silence or a party line (Forester, 1980). Healey (1994) has made some contributions to our understanding of communicative theory in planning. According to Healey (1992) planning should be an interactive and interpretative process which focuses on searching for achievable levels of mutual understanding and is a participatory based discussions.

Case studies and pilot practices have provided some optimistic results about the application of this approach by highlighting the effectiveness and importance of communicative actions in planning. ${ }^{3}$ Forester (1989) applied Habermasian ideas to the study of planning practice in a planning agency. He connected the concept of communicative rationality to planning theory and showed how dialogue can be used to overcome repressive political bounds, such as interpersonal manipulation and structural misinformation, on planning. Many studies in environmental planning have found that within the new forms of societies, planning cannot go ahead without going toward a more participatory and democratic approach (Healey, 1994).

Communicative planning's scope is wide and it can be applied to conflict situations such as those arising from land use disputes. In land use conflicts, planners can apply the communicative approach and can design conflict management approach by considering three linked factors: (a) the negotiation technique, (b) the negotiation forum and (c) the intensity of conflict (Kaiser, et.al., 1995: 462). Susskind and Cruikshank (1987) identified a range of dispute resolution techniques - (a) direct or assisted negotiation, (b) facilitation by a third party, (c) mediation by third party, and (d) arbitration by an arbitrator. Dispute resolution forums, the types of settings in which conflicts are addressed, range from informal meetings among planners, developers and citizens to hearings by judges or attorneys. Godschalk (1992: 369) identifies three different intensity levels of conflicts - (a) issues, moderate level of disagreement, (b) disputes, unresolved issues, and (c) impasses, stalemated disputes.

Consensus ${ }^{4}$ planning (CP) is a mode of the communicative planning and it is based on such approaches as collaboration, negotiation and persuasion, for building consensus for decision. The main characteristic of $\mathrm{CP}$ is that planning

\footnotetext{
${ }^{3}$ For case studies with application of communicative planning, see International Society of Planners (1995). Adaptation and Mediation in Urban Planning - Working Paper Book. Australia: International Society of City and Regional Planners (ISoCaRP). For Caribbean case studies, see Pugh, J. and R.B. Potter (eds) (2003). Participatory Planning in the Caribbean-Lessons from Practice. Aldershot: Ashgate Publishing Ltd.

${ }^{4}$ Consensus refers to a general agreement of opinion or collective opinion in a certain group (Woltjer, 2000, p.6).
} 
products such as public works are created based on opinions. To achieve this, actors with an interest that bears relation to the planning problem under consideration, participate in some co-operative, negotiating or will-shaping process. However, the approach pays equal attention to both the process and the product. The way things are decided is as important as the substantive outcome of decision making. (Woltjer, 2000, p.7).

Woltjer (2000, p.25-6) identified three types of consensus planning: (a) CP as a process of collaboration and learning; (b) $\mathrm{CP}$ as a process of bargaining and negotiations; and (c) $\mathrm{CP}$ as a process of persuasion and will shaping. In reality, the types may overlap and their applications depend on the nature of the planning problems or issues. At the empirical level, Woltjer (2000) has examined a few cases to get an idea of the possible variation in types of CP for infrastructure projects in Netherlands.

Consensus planning as a mode of communicative planning approach has wide potentials to be applied to resolve many planning problems and issues. The present study intends to harness this potential in resolving the three land use conflict cases that have cropped up in Georgetown.

\section{OBJECTIVES AND METHODOLOGY}

In addressing the land use conflict issues of the Jelutong area of Georgetown, the following objectives have been formulated:

- Study the existing land use and identify the prevailing land use conflict cases;

- Identify the conflict parties and conflict interests in each conflict case;

- Analyze the spatial/environmental implications of each land conflict case;

- Determine the factors responsible for the occurrences of the land use conflicts; and

- Develop a consensus planning approach for resolving the land use conflicts.

In order to study the land use conflicts, Jalan Haji Hashim Imam of Jelutong area of Georgetown was selected after reviewing the Draft Structure Plan (Amendment) of MPPP 2000, site observation and also consultation with the Town Planner of MPPP. A four-week long field survey was conducted in 2003 and primary and secondary data were collected. The primary data included the site inventory, observation and photographs, which mainly helped to update the existing land uses and also identification of land use conflict cases. The secondary data included collection of information/reports from MPPP such as 
Land Use Plan, Technical Report of Draft Structure plan (Amendment) MPPP 2000, Policy Plan (Pelan Dasar) of MPPP, committed development and also the environmental guidelines from DOE. Besides these, an interview was conducted with the local authority and conflict parties. Two main policies and guidelines Policy Plan ${ }^{5}$ for Planning and Development Control of MPPP, and the Department of Environment (DOE) Guidelines for the Siting and Zoning of Industries ${ }^{6}$, were used as tools to identify and analyse the land use conflicts in the study area.

\section{THE STUDY AREA}

The study area, Jelutong, is located in Section $9 \mathrm{~W}$ of Georgetown, the state capital of Pulau Pinang which is situated in the northern region of Peninsular Malaysia (Figure 1). It is a suburb strategically located at a distance of $5 \mathrm{~km}$ to the south west of the City Centre and between the City Centre and the Penang Bridge at the south of Georgetown. The study area is connected with two major distributor roads - Jalan Jelutong and Jalan Sungai Pinang. There are many Small and Medium Scale Industries located in Jelutong that has shaped its particular enclave. Many of these industrial premises are located at inappropriate sites thereby creating planning problems like land use conflicts and environmental pollution in the area. The study site constitutes of the land uses around Jalan Haji Hashim Imam. The Municipal Council of Penang Island (MPPP) is the Local Planning Authority whose jurisdiction covers the whole of Penang Island with an approximate area of $293 \mathrm{~km}^{2}$.

${ }^{5}$ The Policy Plan for Planning and Development Control of MPPP provide a specific control on future land use and land development, including the change of land use and building activities within MPPP area. This Policy Plan is also supported by several guidelines that outline control criteria such as housing density, type of building, height, setback, design and other planning aspects.

${ }^{6}$ The DOE guidelines for the siting and zoning of industries cover industry types with related descriptions and standard requirements along with their buffer zones (DOE 1996). 


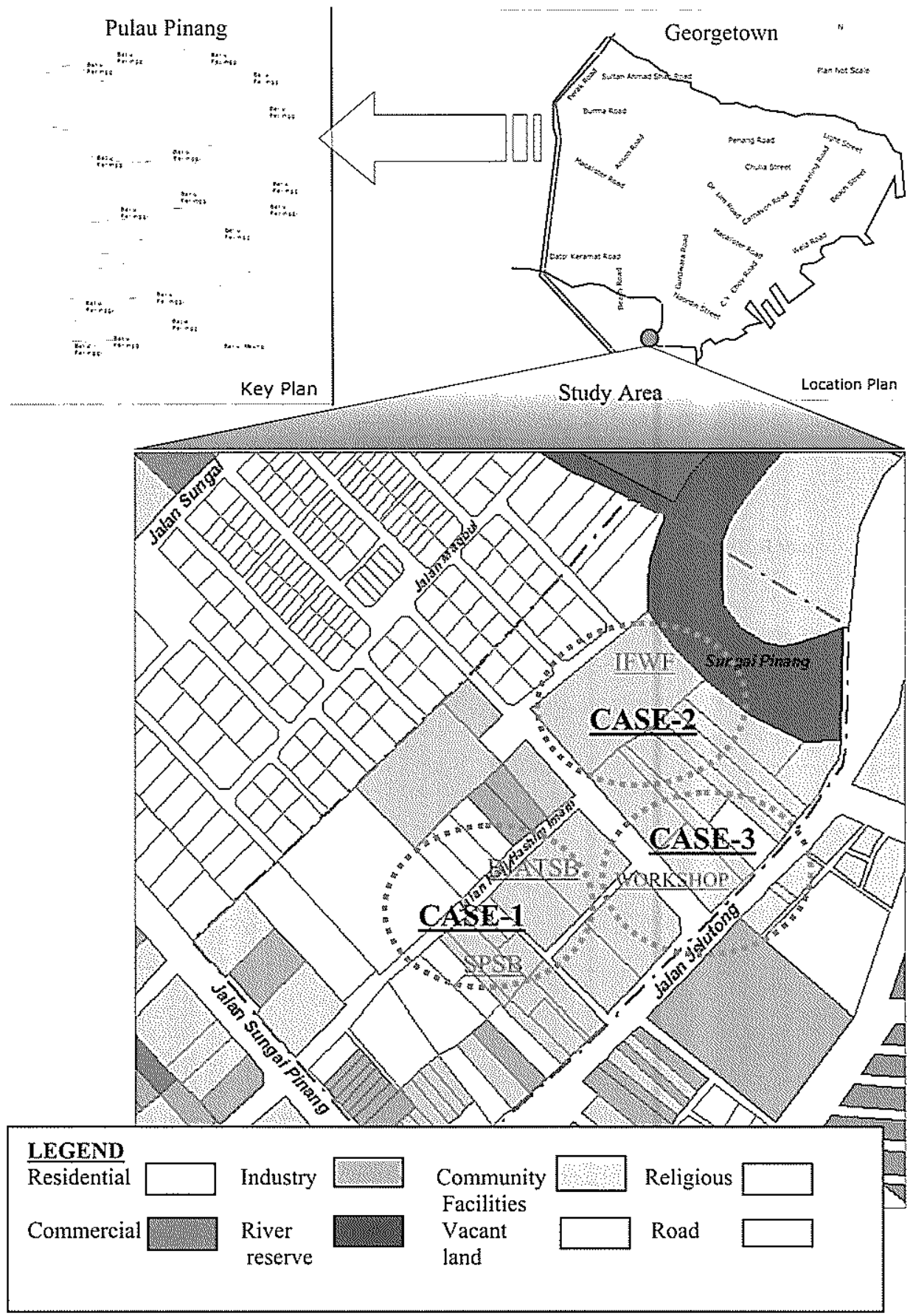

Figure 1: The study area. 


\section{EXISTING LAND USE OF THE STUDY AREA}

The total land of the study site is 15.95 acres or $64,552 \mathrm{~m}^{2}$. The dominant land use of the area as Figure 2 shows is industry which comprises of $19,965 \mathrm{~m}^{2}$ or 30.93 percent of total area. The second dominant land use is residential which occupies $15,965 \mathrm{~m}^{2}$ (24.73 percent), followed by road $-8,889 \mathrm{~m}^{2}(13.77$ percent). Vacant land covers an area of $7,726 \mathrm{~m}^{2}$ (11.97 percent) and river reserve occupies nearly $5,871 \mathrm{~m}^{2}$ (9.1 percent). While commercial land use covers $3,895 \mathrm{~m}^{2}$ (6.03 percent), community facilities occupy $1,213 \mathrm{~m}^{2}$ (1.88 percent). Finally, religious institutions occupy only 1.59 percent or approximately $1,028 \mathrm{~m}^{2}$.

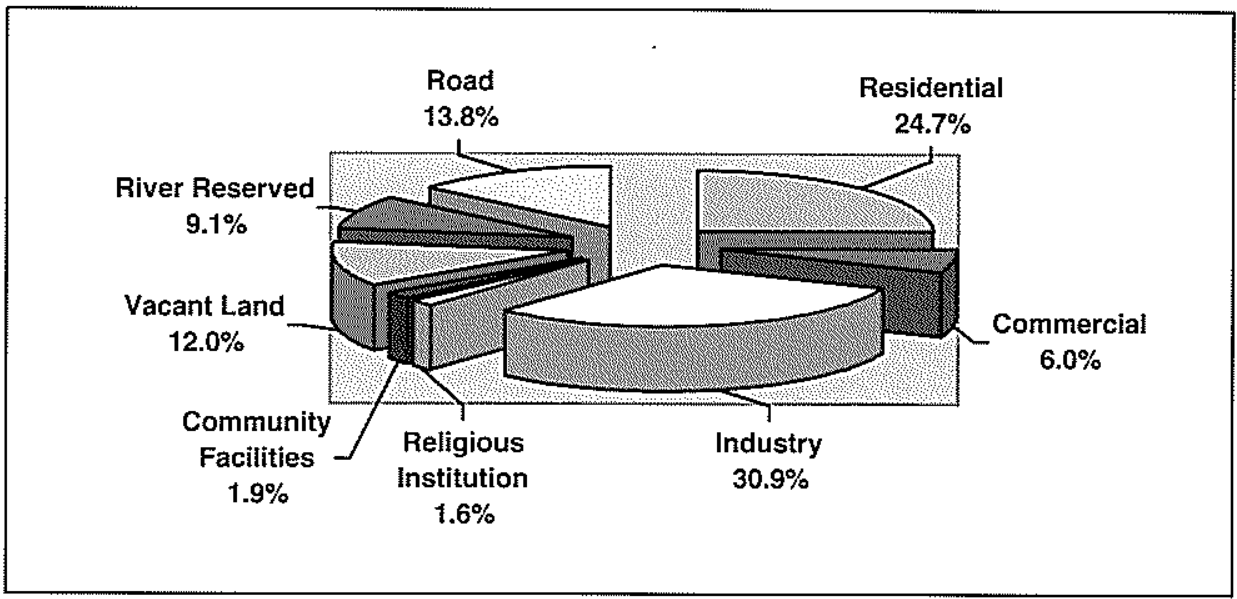

Figure 2: Land use pattern of the study area, 2003.

\section{IDENTIFICATION AND ANALYSIS OF LAND USE CONFLICT CASES}

Three significant land use conflict cases were identified in the study area. These are - (a) the location of two industries in close proximity to a residential area, (b) the location of an industrial premise close to river reserve, (c) the location of a bus workshop near to a residential area (Figure 1).

\section{Case 1: Land Use Conflict due to Location of Industries close to a Residential Area}

Two medium-sized industries - Ban Joo Aun Trading Sdn. Bhd. (BJATSB), located on lots 670 and 680, with an area of 2,162 $\mathrm{m}^{2}$ and Sun Printing Sdn. 
Bhd (SPSB), covering lots $99,100,101,973$, and 974 , with an area of $2,254 \mathrm{~m}^{2}$, are located in close proximity to a residential area. The residential area is situated opposite to those industries but separated by Jalan Haji Hashim, a 7metre local road. BJATSB processes used materials and its main entrance is from the busy road of Jalan Jelutong while the rear entrance is from Jalan Haji Hashim Imam. SPSB is a printing company and it is located in front of Jalan Jelutong while beside it is Jalan Haji Hashim Imam (Figure 1).

Local Authority (MPPP), DOE Penang, the two factories and the residents of Jalan Haji Hashim Imam, are the parties involved in this land use conflict case. Only residential use is permitted in Village Housing Zone and industries are not permitted in the area. Thus, the location of both industries near to the residential area is not appropriate. However, it was argued that these industries had existed before the formulation and enforcement of the MPPP Policy Plan from 1989. This seems valid for BJATSB that had existed in the area for about 30 years, but not for SPSB which began its operation in 1999. According to DOE, the minimum buffer zones between residential area and small and medium scale industries are 30 metres and 250 metres, respectively ${ }^{8}$.

\section{Conflicts of Interests}

Two main conflicts of interests - economic and environmental are evident in this case. Both industries operate in the area because they stand to make profits. The residents in the area have an interest in creating a better living environment and they are also concerned about safety issues as a consequence of living close to industries. Finally, the public authorities are concerned with the preservation of environment and the compliance of industries with the environmental quality standards. Physical conflicts in the form of visual blight and traffic safety also exist in the area due to the environmental problems.

\section{Spatial/Environmental Implications of the Conflict}

The land use conflict case has generated several environmental problems in the form of air, water, soil and noise pollutions, visual blights and safety issues on the affected community.

${ }^{7}$ According to the Schedule 2: Zones of Planning Control of Policy Plan of MPPP, 1989.

${ }^{8}$ Guidelines for the Siting and Zoning of Industries, DOE, 1996. 


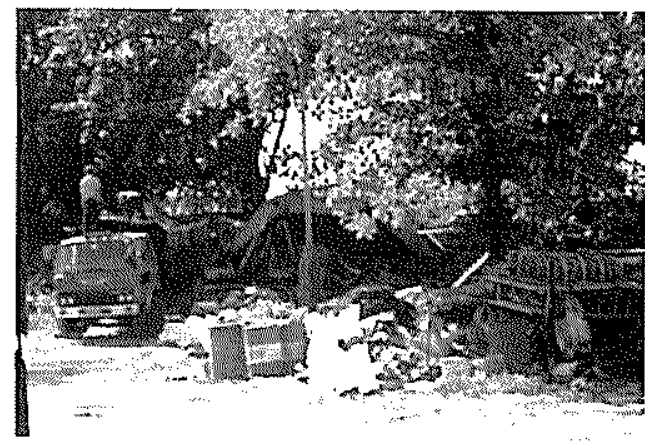

Photo Cl.a: Filthy condition within the factory

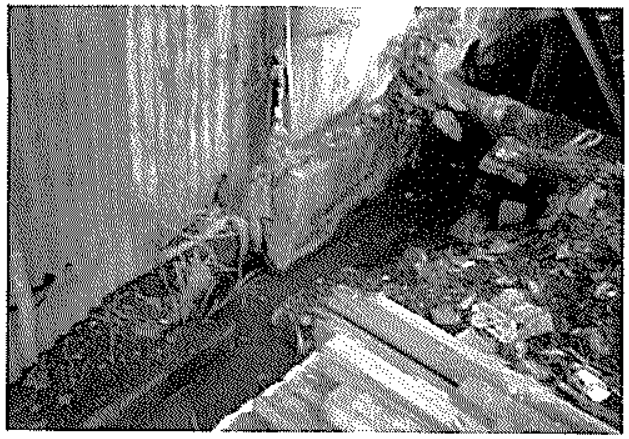

Photo Cl.b: Clogged drain and zinc fence

\section{Case 2: Land Use Conflict due to Location of Factory Adjacent to Environmentally Sensitive Area (River Reserve)}

This case involves the location of a factory adjacent to the Sungai Pinang river reserve. The factory is named International Footwear (Pg) Sdn. Bhd. and it used to manufacture 'Pallas' brand foot wear. This covers lots 109 and 482 with an area of $9,421 \mathrm{~m}^{2}$ which is 47.2 percent of total industrial acreage of the study site (see Figure 1). The factory has been abandoned since 2002. The Sungai Pinang river is classified as a 'polluted' river and it does not meet up with Class IV Standard of the water quality index ${ }^{9}$. The pollutants of Sungai Pinang mostly come from the wastes discharged from sources both domestic and industries.

The Local Authority (MPPP), DOE Penang, Department of Irrigation and Drainage (DID) Penang, Footwear factory, Kariah Committee of Masjid Maqbul, and the residents of Jalan Maqbul and part of Jalan Haji Hashim Imam, are the parties involved in this land use conflict case. About one-fifth of the factory area has encroached on the river bank. No development except for government and community facilities is permitted in the river reserve zone ${ }^{10}$. Nevertheless, the location of the abandoned factory complies with the permitted zoning due to the fact that the factory was operating before the formulation of the Policy Plan. Usually, a medium scale industry should be located either in a designated industrial estate or zone or it should have a buffer of 250 metres from other land uses ${ }^{11}$. But the factory being located in the river reserve does

\footnotetext{
${ }^{9}$ According to the Technical Report of DSPMPPP 2000.

${ }^{10}$ Referring to the Policy Plan of MPPP, 1989.

${ }^{11}$ Referring to the Guidelines for the Siting and Zoning of Industries, DOE, 1996.
} 
not comply with the guideline; rather, it has created land use conflicts with the residential area of Jalan Maqbul, which is separated by a 5-metre road.

\section{Conflicts of Interests}

Two types of conflicts of interests - economic and environmental, are evident in this case. Even though the factory is abandoned, the industrial site still has an interest to maintain its land use status. In fact, the owner has an interest in earning income by renting the premise to other industries. MPPP, DOE and DID have their interests in controlling and preventing pollution in the area. On the other hand, the Kariah Committee of Masjid Maqbul and the residents are interested in quality living environment of the area.

\section{Spatial/Environmental Implications of the Conflict}

The conflict case holds potential environmental problems due to abandoned factory/land, along with the visual blight and safety issues faced by the neighbouring community.

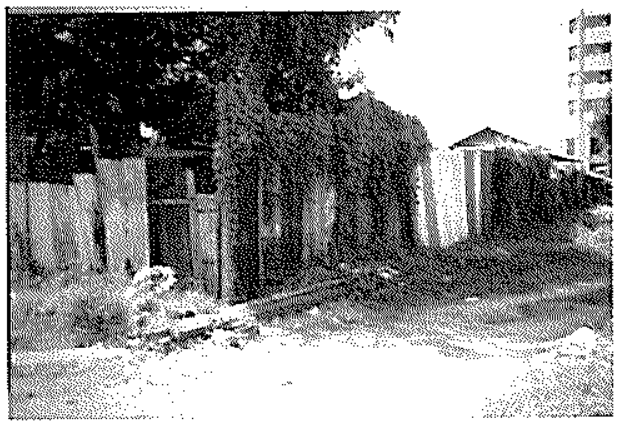

Photo C2.a: Zinc perimeter fencing - visual blight.

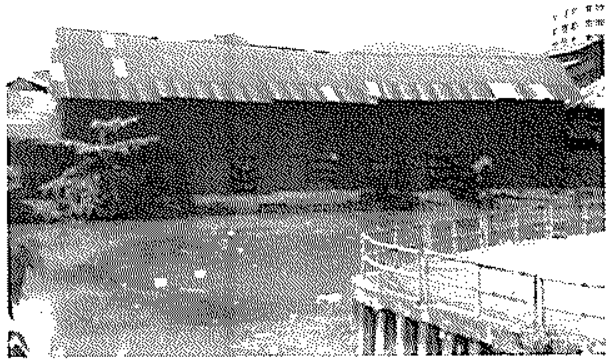

Photo C2.b: Factory and polluted river:

\section{Case 3: Land Use Conflict due to Location of Bus Workshop nearer to a Residential Area}

The third land use conflict case involves the location of a bus workshop within the surrounding land uses. The workshop is strategically located on lot 106 with an area of $963 \mathrm{~m}^{2}$ adjacent to the main road - Jalan Jelutong and in close proximity to the residential areas at Jalan Haji Hashim Imam and Jalan Maqbul (sees Figure 1). It is a rental premise and the tenant is the Konsortium Bas Ekspres Semenanjung Sdn. Bhd. (KBESSB). The workshop has been in operation since 2001 and it provides a number of services such as vehicle 
repairs, fuel loading and washing. Furthermore, the workshop also functions as a depot for all express buses of the company. Thus, the workshop contributes to road congestion and environmental pollution and also threatens the safety of neighbouring residents.

This land use conflict case involves five main parties - the residents of Jalan Haji Hashim and Jalan Jelutong, the morning market operators and visitors, KBESSB, MPPP ${ }^{12}$, and DOE. The workshop is classified as an industrial activity and it complies with the permitted future land use of the area. MPPP has designated the area as industrial mainly because of the development pressure that exists in the area. Being located at a distance of 50 metres from the surrounding residential areas, the workshop is obviously complying with the DOE guidelines ${ }^{13}$. However, it was noticed that the workshop did not adopt proper measures to treat the waste water and therefore it failed to comply with the standard requirements for industrial discharges and emissions of the Environmental Quality Act, 1974.

\section{Conflicts of Interests}

Two types of conflicts of interests - economic and environmental have been identified in this land use conflict case. The bus company has a major interest to maintain the workshop at the existing location because it is strategic and convenient. However, MPPP representing the public interest are struggling to resolve the traffic congestion at major roads of Penang Island including Jalan Jelutong. DOE is concerned with the level of pollution that is mainly contributed by various industrial activities in the urban area. The residents are concerned about their safety and risk of accidents from the movement of buses due to the location of the workshop there.

\section{Spatial/Environmental Implications of the Conflict}

The environmental impacts of this conflict include traffic congestion, air and water pollution and safety issues.

Table 1 provides a comparative analysis of the three land use conflict cases within the framework of the parties involved, conflict of interest, nature of conflict and environmental impacts. Basically, the three conflict cases involve

12 One of the main functions of MPPP is regulating building control within its jurisdiction area as provided by the Street, Drainage and Building Act 1974 (Act 133). The main purpose of building control is to ensure safety of structures, standards of size and space and also healthy and sanitary habitation.

${ }_{13}$ According to the DOE Guidelines for the Siting and Zoning of Industries, the minimum buffer zone for a light scale industry is 30 metres. 
both public and private parties; their occurrences are dominated by strong economic interests; however, their environmental impacts are wide-ranging.

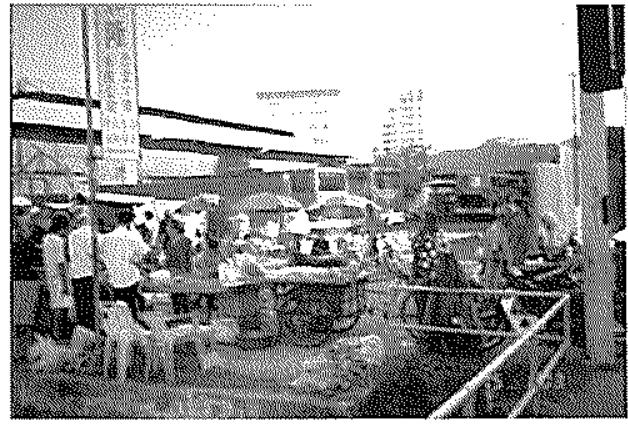

Photo C3.a: Morning market and bus

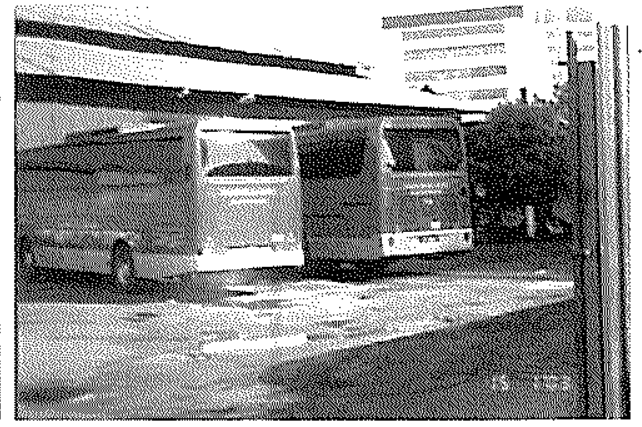

Photo C3.b: Buses creating environmental

Table 1: Comparative analysis of the three land use conflict cases.

\begin{tabular}{|c|c|c|c|c|c|}
\hline $\begin{array}{c}\text { CONFLICT } \\
\text { CASES }\end{array}$ & $\begin{array}{l}\text { Parties } \\
\text { Involved }\end{array}$ & $\begin{array}{l}\text { Conflict of } \\
\text { Interests }\end{array}$ & \multicolumn{2}{|c|}{ Nature of Conflict } & Impacts \\
\hline \multirow{3}{*}{$\begin{array}{l}\text { CASE 1: } \\
\text { Location of } \\
\text { industries close } \\
\text { to residential } \\
\text { area. (Lots: } 670 \text {, } \\
680,99-101, \\
973-4) .\end{array}$} & \multirow{3}{*}{$\begin{array}{l}\text { 1. Private } \\
\text { sector } \\
\text { (industries); } \\
\text { 2. Public } \\
\text { sector } \\
\text { (MPPP, } \\
\text { DOE); and } \\
\text { 3. Residents }\end{array}$} & \multirow{3}{*}{$\begin{array}{l}\text { 1. Economic } \\
\text { 2. Environment } \\
\text { 3. Living } \\
\text { environment } \\
\text { 4. Safety }\end{array}$} & \multirow{3}{*}{ Spatial $_{\text {Physical }}$} & \multirow{3}{*}{ 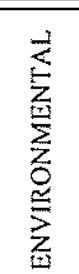 } & 1.Air pollution \\
\hline & & & & & $\begin{array}{l}\text { 2. Water, soil and } \\
\text { noise pollution }\end{array}$ \\
\hline & & & & & $\begin{array}{l}\text { 3. Visual blight, } \\
\text { safety issues }\end{array}$ \\
\hline \multirow{3}{*}{$\begin{array}{l}\text { CASE 2: } \\
\text { Location of } \\
\text { factory adjacent } \\
\text { to river reserve. } \\
\text { (Lots: } 109,482 \text { ) }\end{array}$} & \multirow{3}{*}{$\begin{array}{l}\text { 1. Private } \\
\text { sector } \\
\text { (industries); } \\
\text { 2. Public } \\
\text { sector } \\
\text { (MPPP, DOE, } \\
\text { DID); } \\
\text { 3. Residents; } \\
\text { 4. Masjid } \\
\text { Committee }\end{array}$} & \multirow{3}{*}{$\begin{array}{l}\text { 1. Economic } \\
\text { 2. Environment } \\
\text { 3. Living } \\
\text { environment } \\
\text { 4. Conservation } \\
\text { of Masjid }\end{array}$} & \multirow{3}{*}{\multicolumn{2}{|c|}{ Spatial }} & $\begin{array}{l}\text { 1. Environmental } \\
\text { hazards. }\end{array}$ \\
\hline & & & & & $\begin{array}{l}\text { 2. Water, soil and } \\
\text { noise pollution. }\end{array}$ \\
\hline & & & & & $\begin{array}{l}\text { 3. Visual blight, } \\
\text { safety issues. }\end{array}$ \\
\hline \multirow{3}{*}{$\begin{array}{l}\text { CASE 3: } \\
\text { Location of bus } \\
\text { workshop } \\
\text { nearer to } \\
\text { residential area. } \\
\text { (Lot: 106) }\end{array}$} & \multirow{3}{*}{$\begin{array}{l}\text { 1. Private } \\
\text { sector (Bus } \\
\text { workshop); } \\
\text { 2. Public } \\
\text { sector } \\
\text { (MPPP, } \\
\text { DOE); } \\
\text { 3. Residents, } \\
\text { 4. Market } \\
\text { operators \& } \\
\text { visitors }\end{array}$} & \multirow{3}{*}{$\begin{array}{l}\text { 1. Economic } \\
\text { 2. Environment } \\
\text { 3. Traffic safety } \\
\text { 4. Living } \\
\text { environment }\end{array}$} & \multirow{3}{*}{\multicolumn{2}{|c|}{$\begin{array}{l}\text { Economic } \\
\text { Spatial } \\
\text { Physical }\end{array}$}} & $\begin{array}{l}\text { 1. Air and water } \\
\text { pollution. }\end{array}$ \\
\hline & & & & & $\begin{array}{l}\text { 2. Environmental } \\
\text { hazards. }\end{array}$ \\
\hline & & & & & $\begin{array}{l}\text { 3. Traffic } \\
\text { congestion, } \\
\text { safety issues. }\end{array}$ \\
\hline
\end{tabular}

(Source: Authors' analysis based on field survey data collected in 2003) 


\section{REASONS FOR THE CONFLICTS}

Based on the analysis of the three conflict cases, the following reasons appear responsible for the existence of land use conflicts in the area:

\section{a. Local Plan of MPPP is still under preparation}

From the analysis it appears that the main source of conflict is derived from the incompatibility of land uses between industries and residential areas. This situation has occurred because the Policy Plan of MPPP only provides general land use and development guidelines. Therefore, there is a serious need for a Local Plan to be prepared and gazetted in order to provide a comprehensive and effective control on future land use and development within MPPP area. The delay of its preparation is due to the recent amendment of Act 172 that requires the Local Plan to be in compliance with the State Structure Plan which is still under preparation ${ }^{14}$.

\section{b. Lack of Co-ordination among Public Agencies}

Incompatibility of industrial land use within the surrounding residential environment is the prime reason for the occurrence of land use conflicts in the study area. Although the first and second cases comply with the land use zoning of MPPP, both cases do not comply with the minimum buffer zone requirements of the DOE. It was reported that the DOE guidelines were prepared after the Policy Plan of MPPP and as a result it has not been incorporated in the Policy Plan. This indicates lack of coordination between public agencies.

\section{c. Delay in enforcing statutory laws}

The monitoring and enforcement of development activities involve a longer period of time, and it eventually leads to prosecution action in the courts $^{15}$. Usually, a license or permit is issued by a local authority to a business or industrial operator for a period of one year and it must be renewed. Therefore, as a control tool, the license renewal is more stringent and effective compared to planning or building control. In addition, MPPP

\footnotetext{
${ }^{14}$ Referring to Section 8 and 12, Town and Country Planning Act 1976 (Act A1129).

${ }^{15}$ This includes complying with statutory laws such as Town and Country Planning Act 1976 (Act 172) and the Street, Drainage and Building Act 1974 (Act 133) in particular to building control as prescribed under Section 70. On the other hand, referring to the Section 3 of the Trades, Businesses and Industries By-Laws of MPPP 1991 stated the requirement for industrial operators to obtain license from MPPP.
} 
can serve a requisition notice to the landowner if it is not satisfied with the present use of land ${ }^{16}$.

\section{d. Lack of Network Relationship among Conflict Parties}

All the three conflict cases involve broadly three parties - (a) public agencies like MPPP, DOE, DID; (b) private sector; and (c) the residents. The network relationship within each party exists but there is no platform for cross-party networks in order to resolve the conflict situations.

\section{POLICY OPTIONS}

Land use conflicts can be resolved through an effective conflict management. The conflict management begins with the identification of alternatives and followed by a description of shift and power, which could guide the formulation of conflict resolutions. Therefore, the paper proposes five alternative approaches which can be directed at facilitating the overall conflict resolution process.

\section{a. 'Do Nothing'}

This approach is adopted when the local authority has no intention to intervene in the conflict situation. In such a case, the land use conflicts will be resolved by the market force only. However, this may lead to further deterioration of the living environment.

\section{b. Physical Measures}

Physical measures refer to long-term actions taken by the local authority (MPPP) to resolve the land use conflicts. However, this approach has two main disadvantages - it is time consuming and costly. For example, a road widening project of Jalan Haji Hashim Imam from 7 to 17 metres will temporarily mitigate some of the land use conflicts in the area but the project will be very expensive.

\section{c. Relocation of Factories in Industrial Areas}

MPPP is committed to promote a conducive environment for living, working and recreation as outlined in the goal of DSPMPPP 2000. In order

\footnotetext{
16 Under Section 30 of TCPA 1976 (Act 172), MPPP with the approval of the State Authority could use its power to serve requisition notice to land owner under certain circumstances.
} 
to realize this goal aimed at reducing land use conflicts, MPPP can encourage the four industries to be relocated at the designated industrial zones and convert these spaces into recreational activities. This would require MPPP to go for land acquisition for public purposes and this will be very costly because MPPP must offer considerable amount of compensation as required ${ }^{17}$.

\section{d. Formation of Resident Association and Dialogue}

In order to protect their interest and rights, the residents should form an association. The main task of the association is to act as a representative body to carry on dialogues with the public agencies and the industry owners. The dialogue can be an open dialogue involving all conflict parties and interested parties such as NGO and academicians, or a closed dialogue that only involves the conflict parties. However, the success of this approach to resolve land conflicts is uncertain.

\section{e. Consensus Building}

In order to achieve a firm conflict resolution and a 'win-win' situation, MPPP can initiate a consensus conflict resolution with all the parties. A consensus building is a compromise approach of decision making where individuals or organizations with interests can communicate to reach an agreement which is far from the formal planning approach. Consensus exists when all participants find the result is acceptable and it is not necessary for the participants to agree on every aspect of the resolution.

For the land use conflict cases in the study area, MPPP can act as a mediator and initiate a dialogue session with the affected/ interested parties. In this case, a 'persuasion' and 'bargaining' rather than the 'coercion' and 'debate' technique should be pursued and a closed dialogue should be encouraged. For the first land use conflict case, MPPP's initiative to consensus building can lead to a decision in which the printing company (SPSB) should be agreed to relocation outside the area and the processing factory (SAJTSB) can continue operation after it conforms to certain environmental improvement conditions, including allowing MPPP to create a minimum buffer zone for which SAJTSB has to sacrifice some land for widening the road.

${ }^{17}$ The use of power by MPPP is in line with Section 3 of Land Acquisition Act 1960 (Act 486), provided that the land acquisition is carried out for public purposes. 
For the second land use conflict case, MPPP's initiative to consensus building can lead to a decision in which case the industrial premise will be acquired by MPPP ${ }^{18}$ and a new industrial site can be offered at the PDC Industrial Estates at Bayan Lepas. The industrial land acquired can be used for constructing a local park by MPPP. Thus, with the relocation of the factory, the land use conflicts can be resolved towards creating a better living environment in the area.

Finally, the third land use conflict case can be resolved through a consensus building leading to a decision in which case the bus workshop can retain its operation at the existing location but it has to adopt a proper mechanism to treat the waste water discharge immediately as laid down by DOE and also improve its traffic and safety management. MPPP can also help remove the 'morning market' from its current location nearer to the workshop entrance to a location at Jalan Haji Hashim Imam. These consensus decisions will help improve the living environment of the area.

\section{CONCLUSION}

This paper has examined and analysed the reasons for the existence of three land use conflict cases that have occurred in the Jelutong area of Georgetown due to the location of industries adjacent to the residential areas. Each of the land use conflict situations has generated several environmental impacts which require resolution by adopting an appropriate approach. Several alternative approaches to resolve the land use conflicts and mitigate the environmental impacts have been suggested and evaluated with a consensus planning approach which appears to be most feasible mode of communicative approach. Nevertheless, each land use conflict case requires a different type of conflict resolution through consensus building. In short, a conflict resolution should be designed according to a specific conflict case. However, in order to achieve a consensus conflict resolution, it is important to acknowledge that the resolution may not fully satisfy the interest of each conflict party due to the fact that a consensus conflict resolution may insist on a change in attitude and principle of each party. MPPP as a Local Planning Authority will be effective in any land use conflict situation. With a good co-operation from the conflicting agencies, MPPP can function as a mediator effectively.

\footnotetext{
${ }^{18}$ The action of MPPP shall be in line with the provision of TCPA 1976 (Act 172) and related procedures.
} 


\section{REFERENCES}

Asgary, Ali \& Saki, Afsaneh. 1995. Communicative Planning Theory: A Mediation Approach in Planning, in ISoCaRP, Adaptation and Mediation in Urban Planning, Working Paper-1.

Burby, R.J and Moore, D.M. 2000. Living with Industry in Compact Communities: Neighbourhood Safety and Quality of Community Life, in Roo, Gert de and D. Miller (eds.). Compact Cities and Sustainable Urban Development. Aldershot: Ashgate Publishing Ltd, 127-49.

Chan, Pun Chung 1997. Tackling the Problem of Conflicting Land Use in Hong Kong: A Planner's View, in Miller, D. and Gert de Roo (eds.)(1997). Urban Environmental Planning. Aldershot: Ashgate Publishing Ltd, 29-39. Department of Environment 1996. Guidelines for Siting and Zoning of Industries. KL: DOE.

Forester, J. 1980. Critical Theory and Planning Practice, Journal of American Planning Association, 275-84.

Forestor, J. 1992. Planning Through Debate, Town Planning Review, 63(2), 143-62.

Godschalk, D. R. 1992. Negotiating Intergovernmental policy conflicts: Practice-based guidelines, Journal of the American Planning Association, 58(3), 368-78.

Government of Malaysia 2001. Town and Country Planning Act (Amendment) 2001.

Habermas, J. 1984. The Theory of Communicative Action. London: Polity Press. Healey, P.1994. The Argumentative Turn in Planning Theory and Its Implication for Spatial Strategy Formation. Paper for the Conference on Planning Theory and Social Theory, University of Tampare, Finland.

Healey, P. 1992. Planning Through Debate, Town Planning Review, 63(2), 14362.

International Society of Planners 1995. Adaptation and Mediation in Urban Planning - Working Paper Book. Australia: International Society of City and Regional Planners (ISoCaRP).

Kaiser, E.J., Godschalk, D.R. and Chapin, F.S. Jr. 1995. Urban Land Use Planning. $4^{\text {th }}$ Edition. Chicago: University of Illinois Press.

Khoo Su Nin 1993. Streets of Georgetown, Penang. Penang: Janus Print and Resources.

Municipal Council of Penang Island (MPPP) 2000. Draf Rancangan Struktur (Pengubahan) Majlis Perbandaran Pulau Pinang 2000. Pulau Pinang: MPPP.

Municipal Council of Penang Island (MPPP) 1998. Laporan Penyemakan Rancangan Struktur (Pengubahan) Majlis Perbandaran Pulau Pinang. Pulau Pinang: MPPP. 
Municipal Council of Penang Island (MPPP) 1996. Pelan Dasar Perancangan dan Kawalan Pemajuan. Pulau Pinang: MPPP.

Miller, D. and Roo, Gert de 1997. Urban Environmental Planning. Aldershot: Ashgate Publishing Ltd.

Pugh, J. and R.B. Potter (eds) 2003. Participatory Planning in the Caribbean Lessons from Practice. Aldershot: Ashgate Publishing Ltd.

Roo,Gert de and Miller, D. 2000. Compact Cities and Sustainable Urban Development. Aldershot: Ashgate Publishing Ltd.

Roo, Gert de 2003. Environmental Planning in the Netherlands: Too Good to be True. Aldershot: Ashgate Publishing Ltd.

Susskind, L. and J. Cruikshank 1987. Breaking the Impasse: Consensual Approaches to Resolving Public Disputes. New York: Basic Books.

Woltjer, J. 2000. Consensus Planning. Aldershot: Ashgate Publishing Ltd. 


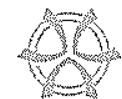

PLANNING MALAYSIA

Joumal of the Malaysian Institute of Plamers (2007) V, $113-129$

\title{
KOMUNITI MAPAN: \\ PENILAIAN TAHAP KEMAPANAN KOMUNITI ORANG ASLI TEMIAR DI NEGERI PERAK
}

\author{
Khairul Hisyam Bin Kamarudin ${ }^{1}$ \\ Jabatan Kejuruteraan Awam \\ Kolej Sains dan Teknologi \\ UTM City Campus, Kuala Lumpur, MALAYSIA \\ Ibrahim Bin Ngah ${ }^{2}$ \\ Jabatan Perancangan Bandar dan Wilayah \\ Fakulti Alam Bina \\ UTM Skudai, Johor, MALAYSIA
}

\section{Abstract \\ SUSTAINABLE COMMUNITY: \\ AN EVALUATION ON SUSTAINABILITY LEVEL OF ORANG ASLI TERMIAR COMMUNITY IN PERAK}

In the declaration of the Conference on Environment and Development at Rio de Janeiro 1992, the role of indigenous people in environmental management and development for achieving sustainability was recognized because of their knowledge and traditional practice. However, the value and traditional practices of the indigenous communities today has gradually disappeared due to pressure from modemization and influence of market economy, which penetrated them. The study examine the extent to which the knowledge and practice of the Orang Asli community comply with sustainable development principles and how their knowledge and practice could be used to derive a framework for sustainable development strategies of Orang Asli community. As an introduction, this article present an alternative thought on the concept and also suggestions on the characteristics of sustainable community. This study revealed that, sustainable community should be guided by a set of system which maintains the relationship of trinity; i.e. relationship between Man and his Creator, Man and Man, and Man and Environment. Eventually, this would help to attain balanced and sustained development economically, socially, environmentally and spiritually. Another part of the study involves an in-depth case study on the selected Orang Asli Temiar settlements in the state of Perak. Based on a case study of Orang Asli Temiar communities of Kampung Perjek and Kuala $\mathrm{Mu}$, the study evaluated the level of sustainability of the

\footnotetext{
${ }^{1}$ khisyam@citycampus.utm.my

2 Professor Madya Dr. Ibrahim boleh dihubungi di b-ibrahim@utm.my.
} 
community's base on the indicators formulated. Forty-five (45) indicators were finalized in a comprehensive manner covering economic, social and physical dimensions. These indicators were then categorized into behaviour, system and situational components. Fieldworks were conducted and the level of sustainability of each indicator was analyzed based on the information collected and index was used to measure the overall sustainability. This study shows variability of sustainability levels of each indicator. Findings from the first part of the analysis (sustainability level for each indicator) showed that only nine of the 16 behaviour indicators have achieved sustainability level. Under system category, only two out of 10 indicators achieved the level of sustainability and for indicators under state category, seven out of 19 indicators achieved the sustainability level. Meanwhile, for the index analysis (overall sustainability level of each dimension) it showed that the levels of sustainability were moderate for the social and physical/ecological indicators $(42.1 \%$ and $60.0 \%)$ and low for the economic indicators $(25.0 \%)$. Based on the findings and discussions with the local community, this study suggests a framework for the sustainable development strategy which includes; (1) conserve or encourage continuation of current sustainable practices, (2) improve or change the unsustainable or low level of sustainable practices and (3) develop the potential of the area in a sustainable manner.

Keywords: Sustainable Development, Community, Indicator, Orang Asli, Strategy

\section{APA ITU KOMUNITI?}

Perkataan komuniti telah diberikan pelbagai tafsiran. Kamus Oxford mendefinisikan perkataan community sebagai satu kumpulan manusia yang tinggal dalam satu tempat; secara bersama dan mempunyai kepentingan. Manakala menurut kamus Longman, commtmity ialah sekelompok manusia yang tinggal di dalam suatu kawasan yang sama; berkongsi kerakyatan atau agama atau mempunyai kesamaan dalam sesuatu keadaan. Definisi-definisi tersebut mengklasifikasikan dua elemen penting di dalam pembentukan komuniti iaitu kumpulan manusia yang tinggal di satu tempat yang sama dan berkongsi kepentingan.

Sekumpulan manusia yang hidup bersama sebagai satu komuniti pastinya akan menjalankan pelbagai aktiviti bagi kelangsungan hidup diri dan keluarga serta menambahbaik keadaan dalam komuniti. Oleh yang demikian, setiap komuniti memerlukan suatu sistem hidup yang mantap bagi mengurus serta mengawal organisasi kehidupan dan keperluan yang pelbagai daripada ahli-ahli di dalam komuniti supaya tidak berlaku perlanggaran terhadap hak individu lain serta untuk dijadikan asas bagi memandu tindakan komuniti supaya menghormati lingkungan batas alam semulajadi untuk kepentingan bersama. Dalam konteks ini, komuniti boleh dirumuskan sebagai sekumpulan manusia yang tinggal 
dalam satu kawasan yang sama, mempunyai sistem peraturan tersendiri dan institusi bagi membolehkan ahli-ahlinya hidup secara bersama.

\section{KONSEP KOMUNITI MAPAN}

Selepas terbitnya laporan oleh Suruhanjaya Brundtland pada tahun 1987 yang menjadi asas gagasan kepada pembangunan mapan, pelbagai usaha dijalankan bagi mengintepretasi konsep serta definisi yang umum tersebut menjangkau lapangan yang lebih luas sehingga kepada pembangunan komuniti luar bandar. Bahagian artikel ini menyediakan pandangan alternatif terhadap konsep komuniti mapan dengan harapan membuka ruang percambahan pemikiran mengenainya, dan bagaimana konsep komuniti mapan dapat diterjemah kepada realiti berdasarkan keperluan dan keadaan komuniti luar bandar yang berbeza. Konsep komuniti mapan lahir daripada kesedaran bahawa kelangsungan hidup manusia perlu diteruskán untuk generasi seterusnya dan kepentingan jangka panjang ini bergantung kepada cara komuniti hari ini mengurus, membangun serta mengguna secara mapan sumber-sumber yang terdapat disekitar lingkungan hidup mereka (Khairul Hisyam Kamarudin dan Ibrahim Ngah, 2004).

Perbincangan mengenai komuniti mapan juga tidak dapat lari dari membicarakan tiga dimensi yang menjadi teras kepada pembangunan mapan dan saling kuat terikat antara satu sama lainnya iaitu ekonomi, sosial dan alam sekitar (Moffatt, 1996; Hjorth dan Bagheri, 2006). Idea perancangan komuniti mapan oleh Ibrahim Ngah (2003) misalnya, menggabungkan pengertian pembangunan mapan dan komuniti secara bersepandu di mana beliar telah merumuskan komuniti mapan sebagai komuniti yang menerimapakai cara hidup dan jalan pembangunan yang menghormati dan bertindak dalam lingkungan batas alam semulajadi.

Untuk membentuk komuniti yang dapat menghormati dan bertindak di dalam lingkungan batas yang mampu ditampung alam semulajadi, sistem hidup komuniti perlu dikawal oleh suatu struktur perundangan yang mantap, dapat difahami dan dipatuhi setiap ahlinya. Justeru, konsep komuniti mapan yang ditekankan oleh kajian ini memerlukan tindakan bersepadu berteraskan kekuatan pertalian antara tiga dimensi iaitu:

1. MANUSIA DENGAN MANUSIA - kemapanan dalam aspek sosial, ekonomi dan politik

2. MANUSIA DENGAN ALAM - kemapanan dalam aspek ekologi 
3. MANUSIA DENGAN PENCIPTA - kemapanan dalam aspek kesedaran adanya tuhan (god consciousness)

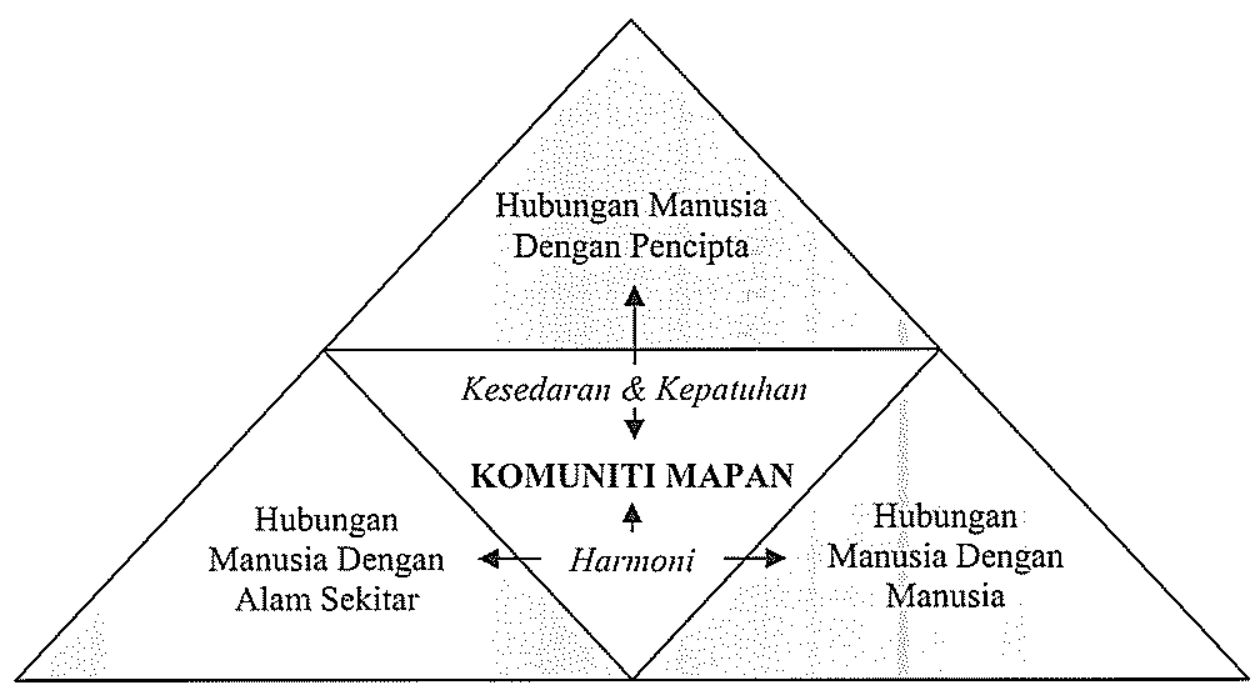

Rajah 1: Cadangan konsep komuniti mapan

Cadangan penulis pada Rajah $I$ di atas bertujuan memperluaskan rangka kefahaman berkenaan komuniti mapan dengan dengan cadangan memasukkan hubungan ketuhanan sebagai salah satu dimensi yang menunjangi konsep tersebut selain hubungan sesama manusia (berkaitan aspek ekonomi, sosial dan politik) dan hubungan dengan alam sekitar (berkaitan aspek ekologi). Jika sebelum ini perancangan pembangunan luar bandar yang mapan dapat menerima integrasi nilai kerohanian sebagaimana dijelaskan pada Doktrin Perancangan dan Pembangunan Sejagat (Zainuddin Muhammad, 1997), adalah tidak mustahil penerapan nilai yang serupa sebagaimana cadangan konsep komuniti mapan luar bandar ini mampu dilaksanakan. Sewajarnya tindakan merancang dan membentuk sistem hidup komuniti yang mantap dan komprehensif memerlukan kefahaman terhadap pencipta sebagai asas mencapai kesejahteraan bagi kehidupan yang berterusan.

Sebagai rumusan, komuniti mapan adalah komuniti yang mempunyai satu sistem hidup yang komprehensif berteraskan ilmu dan budaya bagi mendokong prinsip dan amalan kemapanan. Sistem hidup tersebut mestilah mempunyai interaksi seimbang dan bersepadu antara manusia dengan manusia; manusia dengan alam dan manusia dengan pencipta (Khairul Hisyam Kamarudin dan 
Ibrahim Ngah, 2005). Daripada cadangan konsep komuniti mapan juga, penulis turut mencadangkan ciri-ciri yang perlu terdapat bagi sesebuah komuniti mapan sebagaimana dijelaskan pada Jadual 1 .

Jadual 1: Cadangan ciri-ciri komuniti mapan

\begin{tabular}{|c|c|c|}
\hline & Dimensi Komuniti Mapan & Ciri-Ciri \\
\hline 1 & $\begin{array}{l}\text { Hubungan manusia } \\
\text { dengan manusia } \\
\text { Kemapanan sosial - wujud } \\
\text { satu sistem yang mampu } \\
\text { bertahan dalam menangani } \\
\text { cabaran (atau menerima } \\
\text { perubahan ke arah lebih } \\
\text { baik). Sistem ini didasari } \\
\text { ilmu terhadap kebenaran } \\
\text { dan ilmu saintifik yang } \\
\text { menyokong sistem } \\
\text { kehidupan komuniti } \\
\text { Kemapanan ekonomi - } \\
\text { wujud satu sistem yang } \\
\text { memastikan keadilan dan } \\
\text { keseimbangan di samping } \\
\text { membantuyanglemah }\end{array}$ & $\begin{array}{l}\text { Sosial } \\
\text { - Sistem yang menjana kesinambungan generasi } \\
\text { - Sistem yang menjaga kualiti manusia } \\
\text { Sistem yang menjaga perhubungan lelaki dan } \\
\text { wanita } \\
\text { O Institusi perkahwinan } \\
\text { ○ Tatacara bersosial/pergaulan } \\
\text { o Institusi keluarga } \\
\text { - Sistem yang mengawal kemudaratan akibat } \\
\text { kepincangan hubungan bersama } \\
\text { o Institusi kehakiman/pelaksana hukum } \\
\text { Ekonomi } \\
\text { - Sistem yang menjamin keadilan dalam } \\
\text { komuniti } \\
\text { - Sistem yang menjamin kesamaan peluang } \\
\text { - Sistem yang menjamin kesinambungan di } \\
\text { dalam agihan hasil/kekayaan } \\
\text { - Wujud mekanisma khusus bagi memastikan } \\
\text { keberkesanan terhadap aktiviti ekonomi } \\
\text { Sistem membantu yang lemah } \\
\text { Politik } \\
\text { - Sistem yang menggalakkan penglibatan/ } \\
\text { penyertaan ahli dalam komuniti memberikan } \\
\text { idea } \\
\text { Sistem yang menampakkan kepatuhan kepada } \\
\text { pemimpin yang dilantik selagi berlaku adil } \\
\text { Sistem penguatkuasaan peraturan dan undang- } \\
\text { undang }\end{array}$ \\
\hline
\end{tabular}


Jadual 1: Sambungan...

\begin{tabular}{|c|c|c|}
\hline & imensi Komuniti Mapan & \\
\hline 2 & $\begin{array}{l}\text { Hubungan manusia } \\
\text { dengan alam sekitar } \\
\text { Kemapanan ekologi - } \\
\text { wujud satu sistem yang } \\
\text { mampu menguatkuasakan } \\
\text { tindakan terhadap } \\
\text { penggantian sumber, kitar } \\
\text { semula, rawatan sisa dan } \\
\text { pemeliharaan stumber di } \\
\text { samping terdapat } \\
\text { mekanisma institusi yang } \\
\text { mengawal sistem } \\
\text { hubungan ini }\end{array}$ & $\begin{array}{l}\text { Ekologi } \\
\text { - Sistem yang menjamin kesamaan agihan } \\
\text { sumber } \\
\text { - Sistem yang memastikan pemeliharaan } \\
\text { sumber untuk generasi akan datang } \\
\text { - Sistem yang memastikan pemuliharaan } \\
\text { sumber selepas diguna } \\
\text { - Sistem bagi penggantian sumber terutama } \\
\text { yang boleh diperbaharui } \\
\text { - Sistem yang mempraktikkan prinsip 5R dan } \\
\text { penjimatan } \\
\text { - Sistem khusus bagi rawatan sisa hasil } \\
\text { penggunaan sumber alam }\end{array}$ \\
\hline & $\begin{array}{l}\text { Hubungan manusia } \\
\text { dengan pencipta } \\
\text { Suatu sistem yang } \\
\text { memerlukan ahli komuniti } \\
\text { sedar adanya tuhan/huasa } \\
\text { yang mencipta alam }\end{array}$ & $\begin{array}{l}\text { Kerohanian/Spiritual } \\
\text { - Sistem yang mewujudkan kepatuhan kepada } \\
\text { pencipta } \\
\text { - Sistem yang menggalakkan amalan/etika yang } \\
\text { baik dan melarang amalan/etika yang buruk } \\
\text { - Sistem yang memantapkan kekuatan dan } \\
\text { kesucian dalaman diri } \\
\text { - Sistem yang menggalakkan kesederhanaan } \\
\text { hidup }\end{array}$ \\
\hline
\end{tabular}

\section{KEPERLUAN KAJIAN KEMAPANAN KOMUNITI ORANG ASLI}

Di dalam deklarasi Persidangan bagi Alam Sekitar dan Pembangunan di Rio de Janeiro 1992, peranan penduduk pribumi di dalam pengurusan alam sekitar dan pembangunan untuk mencapai kemapanan hasil amalan dan ilmu pengetahuan tradisional mereka telah disentuh secara khusus di dalam Prinsip ke-22 deklarasi iaitu:

Indigenous people and their communities and other local communities, have a vital role in environmental management and development because of their knowledge and traditional practices. States should recognize and duly support their identity, culture and interest and enable their effective participation in the achievement on sustainable development

(Earth Summit, 1992: 13) 
Banyak penyelidikan yang dibuat menunjukkan terdapat peranan penting dan sumbangan ilmu pengetahuan pribumi dan amalan-amalan yang menjurus kepada kemapanan (Loomis, 2000; Musiiwa, 2002; Pulido dan Bocco, 2003; Karjala dan Dewhurst, 2003). Bagaimanapun, nilai dan amalan tradisional komuniti tersebut hari ini dilihat mulai lenyap disebabkan tekanan oleh arus pemodenan dan penerimaan meluas sistem ekonomi bebas yang berasaskan pasaran (laissez-fair economy) yang mereka sendiri dilihat belum bersedia sepenuhnya. Berdasarkan hujah di atas, kajian ini dilihat penting bagi mengenalpasti di samping untuk menilai sejauh mana prinsip-prinsip yang terkandung di dalam konsep pembangunan mapan diamalkan di kalangan komuniti Orang Asli serta bagaimana ilmu pengetahuan dan amalan mereka ini dapat digunakan untuk memandu arah pembentukan kerangka strategi pembangunan mapan komuniti tersebut pada masa yang akan datang.

\section{INDIKATOR KOMUNITI MAPAN}

Terdapat beberapa literatur yang menyentuh berkenaan pembangunan indikator komuniti mapan (lihat Copus dan Crebtree, 1996; Peterson, 1997; Jackson dan Robert, 2000; Yuan et al., 2003). Namun setelah diadakan perbincangan bersama-sama pakar di bidang tersebut serta penilaian terhadap kesesuaian setiap indikator yang ingin dipilih dengan keperluan kajian, pengkaji telah memilih dan menyenarai pendek sebanyak 45 indikator yang sesuai digunapakai untuk kajian ini. Indikator tersebut merangkumi dimensi ekonomi, sosial dan fizikal/alam sekitar serta dikategorikan kepada 3 komponen iaitu sikap, sistem dan situasi (Jadual 2).

Jadual 2: Cadangan indikator komuniti mapan

\begin{tabular}{|c|c|c|c|c|c|c|}
\hline Komponen & \multicolumn{2}{|c|}{$\begin{array}{l}\text { Indikator } \\
\text { Ekonomi }\end{array}$} & \multicolumn{2}{|c|}{$\begin{array}{c}\text { Indikator } \\
\text { Sosial }\end{array}$} & \multicolumn{2}{|c|}{$\begin{array}{c}\text { Indikator } \\
\text { Fizikal \& Alam } \\
\text { Sekitar } \\
\end{array}$} \\
\hline Sikap & $\begin{array}{l}(1) \\
(12) \\
(15) \\
(16)\end{array}$ & & $\begin{array}{l}\text { (2) } \\
(3) \\
(4) \\
(5)\end{array}$ & $\begin{array}{l}\text { (6) } \\
(7) \\
\text { (14) }\end{array}$ & $\begin{array}{l}(8) \\
(9) \\
(10) \\
(11)\end{array}$ & (13) \\
\hline Sistem & $\begin{array}{l}(36) \\
(37) \\
(38)\end{array}$ & $\begin{array}{l}(39) \\
(40) \\
(41) \\
\end{array}$ & $\begin{array}{l}(42) \\
(43) \\
(44)\end{array}$ & & (45) & \\
\hline
\end{tabular}




\begin{tabular}{|c|c|c|c|c|}
\hline Situasi & $\begin{array}{l}(17) \\
(18) \\
(19) \\
(25) \\
(26) \\
(30)\end{array}$ & $\begin{array}{l}(20) \\
(21) \\
(22) \\
(23) \\
(24) \\
(27)\end{array}$ & $\begin{array}{l}(28) \\
(29) \\
(31)\end{array}$ & $\begin{array}{l}(32) \\
(33) \\
(34) \\
(35)\end{array}$ \\
\hline & & & & \\
\hline
\end{tabular}

Indikator-indikator:

1) Menyimpan wang

2) Bersukan

3) Merokok

4) Aktiviti kebudayaan

5) Bergotong-royong

6) Berpersatuan

7) Rancangan pembangunan komuniti

8) Penggunaan kimia dalam pertanian

9) Amalan guna semula

10) Amalan mengurangkan penggunaan

11) Amalan merawat/membaikpulih

12) Mengoptimumkan penggunaan halaman

13) Menjaga kebersihan halaman

14) Kesanggupan membantu jiran

15) Pekerjaan sampingan

16) Penglibatan ahli keluarga dalam pekerjaan

17) Kadar pengangguran

18) Pemilikan tanah

19) Mengusahakan tanah secara ekonomik

20) Aksess kepada khidmat kesihatan

21) Kadar jenayah
22) Kadar masalah sosial

23) Kadar penceraian

24) Pemilikan rumah dan infrastruktur

25) Purata pendapatan bulanan isirumah

26) Jumlah simpanan wang

27) Penerimaan pendidikan

28) Keadaan celik huruf

29) Kadar keciciran pelajaran

30) Kadar pergantungan ekonomi

31) Purata saiz isirumah

32) Kemudahan bekalan air

33) Kemudahan bekalan elektrik

34) Kemudahan tandas

35) Situasi pencemaran

36) Tempoh masa bekerja

37) Tahu - sistem pembahagian kerja

38) Amal - sistem pembahagian kerja

39) Tahu - sistem pembahagian hasil

40) Amal - sistem pembahagian hasil

41) Amal - perkongsian hasil

42) Kepatuhan undang-undang/adat

43) Terlibat sistem pembuatan keputusan

44) Pengasingan bilik anak lelaki-perempuan

45) Pengurusan sisa dan sampah

KAWASAN KAJIAN: KOMUNITI ORANG TEMIAR.KG. PERJEK DI RPS LEGAP DAN KG. KUALA MU, POS KUALA MU, KUALA KANGSAR, PERAK

Orang Temiar merupakan salah satu sukubangsa daripada kumpulan etnik Senoi, yang kebanyakannya ditemui di bahagian utara negeri Perak dan selatan negeri Kelantan. Sukubangsa ini mewakili kira-kira 16 peratus daripada populasi Orang Asli Semenanjung Malaysia. Di dalam kajian ini, dua perkampungan komuniti Temiar di daerah Kuala Kangsar telah dipilih iaitu $\mathrm{Kg}$. 
Perjek di Rancangan Pengumpulan Semula (RPS) Legap, dan Kg. Kuala Mu di Pos Kuala Mu (Rajah 2).

Kg. Perjek merupakan salah sebuah kampung yang terletak di bawah RPS Legap yang mula dilaksanakan pada tahun 1982. Dengan keluasan tanah 44.6 hektar, kampung ini terdiri daripada 35 buah rumah, di mana 12 buah daripadanya merupakan rumah baru (binaan konkrit) yang diterima di bawah Program Perumahan bagi Rakyat Termiskin (PPRT). Seramai 187 orang mendiami perkampungan ini dengan 49 peratus lelaki dan 51 peratus perempuan. Kemudahan air di perkampungan ini dibekalkan melalui sistem paip air graviti dan bekalan elektrik pula dijana oleh sebuah generator petrol sumbangan Jabatan Kemajuan Islam Malaysia (JAKIM). Kemudahan sosial seperti sekolah rendah dan klinik kesihatan pula terdekat terletak di Pos Legap, kira-kira 2 kilometer dari situ. Aktiviti ekonomi tradisional berbentuk sara diri masih diamalkan sebahagian penduduk kampung terutama golongan tua dengan menanam padi bukit, pisang dan ubi kayu. Kebanyakan golongan dewasa dan anak belia pula memperoleh pendapatan melalui aktiviti penjualan buluh kasap dan menjadi buruh ladang sawit, iaitu skim pertanian yang diusahakan bersama JHEOA dan FELCRA negeri Perak merangkumi tanah seluas kira-kira 400 ekar.

Kg. Kuala Mu pula terletak lebih jauh ke dalam hutan kira-kira 30 kilometer dari Kg. Perjek. Skim pengumpulan semula yang dimulakan pada tahun 1974 ini telah mengumpulkan komuniti-komuniti kecil Orang Temiar yang sebelumnya hidup berselerak di sekitar kaki Gunung Korbu. Kampung ini mempunyai 34 buah rumah dan dihuni seramai 151 orang. Berbeza dengan $\mathrm{Kg}$. Perjek, rumah-rumah di $\mathrm{Kg}$. Kuala $\mathrm{Mu}$ adalah tradisional yang dibina sendiri oleh penduduk daripada buluh dan beratapkan daun bertam. Kampung ini telah dibekalkan sistem paip air graviti daripada sumber air sungai berdekatan dan bekalan elektrik pula diperoleh daripada unit-unit sistem solar individu. Namun, kebanyakan unit-unit solar ini telah rosak akibat tiada penyelenggaraan. Kebanyakan penduduk di kampung ini memperoleh pendapatan melalui jualan hasil hutan seperti rotan, herba, petai dan durian. Cuma sebilangan kecil (kirakira 18 peratus) isirumah yang bekerja sebagai pekebun kecil getah.

Pencapaian pendidikan formal di kedua-dua kampung dilihat masih berada pada paras yang rendah di mana hanya segelintir generasi muda menerima pendidikan sehingga tamat sekolah rendah. Walaupun kedua-dua kampung mempunyai sekolah yang berdekatan, namun untuk melanjutkan pelajaran ke peringkat sekolah menengah penduduk perlu menghantar anak-anak mereka ke sekolah menengah di Sungai Siput atau Ipoh. Kemiskinan dan keengganan 
Daripada jadual hasil analisis di atas didapati 9 daripada 16 indikator Sikap menunjukkan pencapaian tahap kemapanan yang tinggi. Indikator-indikator tersebut ialah penglibatan dalam pekerjaan sampingan $(57.1 \%)$, penglibatan ahli keluarga dalam pekerjaan $(38.1 \%)$, amalan gotong-royong $(90.5 \%)$, penglibatan dalam aktiviti kebudayaan (78.0\%), kesanggupan membantu jiran (95.2\%), penggunaan bahan kimia dalam pertanian $(0.0 \%)$, amalan guna semula $(71.4 \%)$, amalan mengurangkan penggunaan $(81.0 \%)$ dan kekerapan membersihkan halaman rumah $(52.4 \%)$. Di bawah komponen Sistem, hanya 2 daripada 10 indikator mencapai cadangan matlamat kemapanan iaitu indikator kepatuhan undang-undang/adat $(100.0 \%)$ dan amalan pengasingan bilik di antara anak lelaki dan perempuan (71.4\%). Bagi komponen Situasi pula, 7 daripada 19 indikator didapati mencapai cadangan matlamat kemapanan iaitu indikator kadar pengguran $(9.5 \%)$, pemilikan tanah $(77.8 \%)$, aksess kepada kemudahan kesihatan (100.0\%), pemilikan rumah sendiri $(98.4 \%)$, saiz isirumah yang sederhana $(38.1 \%)$, kemudahan bekalan air $(96.8 \%)$ dan tahap pencemaran $(7.9 \%)$.

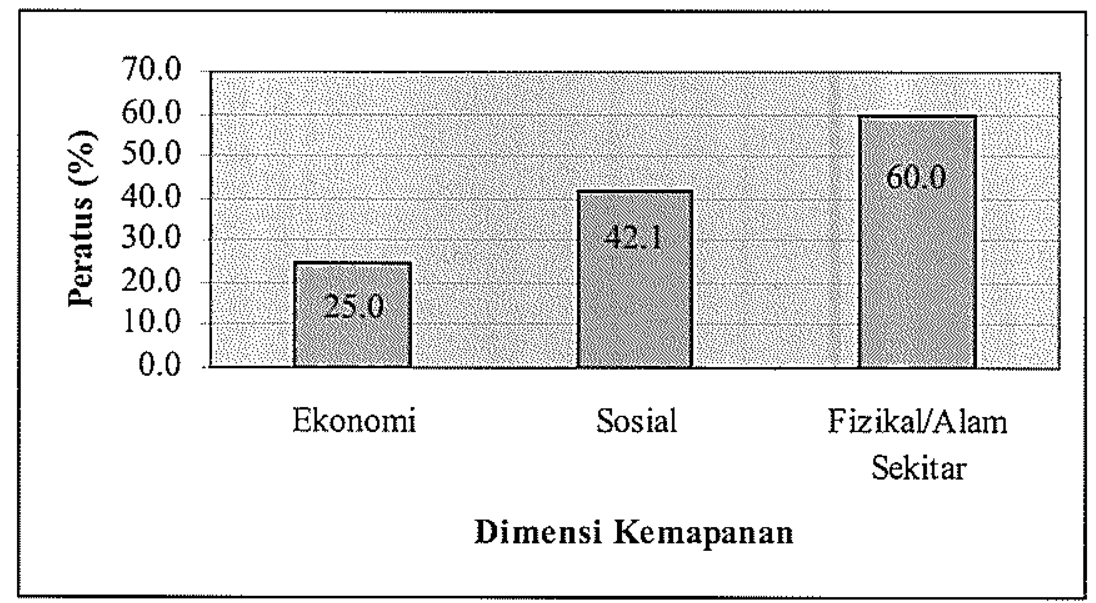

Rajah 3: Tahap kemapanan komuniti berpandukan dimensi kemapanan

Menggunakan kaedah pembahagian matematik ringkas bagi menentukan klasifikasi kemapanan ketiga-tiga dimensi kemapanan, nilai peratus $0-30 \%$ akan mewakili tahap kemapanan rendah; 31-60\% (tahap kemapanan sederhana) dan $61-100 \%$ (tahap kemapanan tinggi). Dengan perbandingan hasil analisis yang ditunjukkan pada Rajah 3, penulis merumuskan bahawa bagi dimensi kemapanan ekonomi dan sosial komuniti secara keseluruhannya berada pada tahap yang rendah $(25.0 \%$ dan $42.1 \%)$. Manakala dimensi fizikal dan alam sekitar pula menunjukkan tahap kemapanan sederhana $(60.0 \%)$, tetapi telah hampir kepada tahap kemapanan tinggi. 
Dapatan analisis ini secara langsung mengingatkan penulis agar memberi tumpuan yang lebih intensif semasa peringkat merancang kerangka strategi pembangunan mapan komuniti kelak. Kerangka strategi yang hendak dibentuk perlulah mengambilkira secara serius pelbagai aspek yang berkaitan pembangunan ekonomi yang maju dan berdaya saing, pembangunan modal insan dan pengupayaan penduduk untuk terbabit secara aktif dengan perancangan dan pembangunan komuniti serta menaiktaraf dan memperbaiki kualiti fizikal dan alam sekitar komuniti bagi kesejahteraan hidup.

Selain analisis data kuantitatif daripada borang soal-selidik, data-data kualitatif menggunakan pendekatan etnografi melalui penglibatan sebagai sebahagian peserta (partial-participant observation) dan temubual mendalam beberapa responden juga turut digunakan bagi menyokong hasil analisis kuantitatif, terutama untuk mengenalpasti permasalahan dan amalan tidak mapan di dalam komuniti yang memerlukan tindakan penyelesaian masalah pada masa hadapan.

\section{Aspek ketidakmapanan dalam komuniti}

Maklumat dan data hasil penglibatan sebagai sebahagian peserta, temubual mendalam ke atas responden serta sesi sumbang saranan bersama wakil penduduk, permasalahan-permasalahan dan aspek ketidakmapanan dalam komuniti telah dikenalpasti dan disenaraikan mengikut kategori-kategori sikap, sistem dan situasi di bawah dimensi ekonomi, sosial dan fizikal/alam sekitar sebagaimana ditunjukkan pada Jadual 4. Hasil analisis terhadap tahap kemapanan dan perbincangan bagi mengenalpasti kaedah penyelesaian terhadap permasalahan/ketidakmapanan komuniti membawa kepada pembentukan kerangka strategi pembangunan komuniti yang dihuraikan pada sub tajuk berikutnya.

Jadual 4: Permasalahan/Amalan tidak mapan di dalam komuniti

\begin{tabular}{|c|c|c|c|}
\hline $\begin{array}{l}\text { Komponen } \\
\text { Komuniti }\end{array}$ & Masalah Ekonomi & Masalah Sosial & $\begin{array}{c}\text { Masalah } \\
\text { Fizikal/Alam } \\
\text { Sekitar }\end{array}$ \\
\hline Sikap & $\begin{array}{l}\text { Tidak membuat } \\
\text { simpanan wang } \\
\text { Halaman rumah } \\
\text { tidak dimanfaat } \\
\text { untuk aktiviti } \\
\text { ekonomi }\end{array}$ & $\begin{array}{ll}\text { - } & \text { Tabiat merokok } \\
\text { - } & \text { Kurang } \\
\text { penglibatan } \\
\text { dalam aktiviti } \\
\text { sukan } \\
\text { Kurang } \\
\text { penglibatan }\end{array}$ & $\begin{array}{ll} & \text { Aspek } \\
\text { pemulihan } \\
\text { sumber kurang } \\
\text { diberi penekanan }\end{array}$ \\
\hline
\end{tabular}




\begin{tabular}{|c|c|c|c|}
\hline Sistem & $\begin{array}{l}\text { Tempoh bekerja } \\
\text { yang pendek } \\
\text { Tiada } \\
\text { pengetahuan } \\
\text { berkenaan cara } \\
\text { agihan kerja } \\
\text { Tiada ilmu } \\
\text { berkaitan } \\
\text { pengagihan hasil } \\
\text { Tidak amalan } \\
\text { pengagihan hasil }\end{array}$ & $\begin{array}{l}\text { dalam } \\
\text { perancangan } \\
\text { komuniti } \\
\\
\text { Sistem yang } \\
\text { kurang } \\
\text { menggalakkan } \\
\text { penglibatan } \\
\text { penduduk dalam } \\
\text { pembuatan } \\
\text { keputusan }\end{array}$ & $\begin{array}{l}\text { Ketiadaan sistem } \\
\text { pengurusan sisa } \\
\text { buangan dan } \\
\text { sampah-sarap } \\
\text { dengan teratur }\end{array}$ \\
\hline Situasi & $\begin{array}{l}\text { Tanah pertanian } \\
\text { tidak diusahakan } \\
\text { secara ekonomik } \\
\text { Pendapatan } \\
\text { bulanan rendah/ } \\
\text { insiden } \\
\text { kemiskinan } \\
\text { tinggi } \\
\text { Simpanan wang } \\
\text { yang rendah } \\
\text { Pergantungan } \\
\text { ekonomi yang } \\
\text { tinggi }\end{array}$ & $\begin{array}{l}\text { Kadar celik huruf } \\
\text { yang rendah } \\
\text { Kadar keciciran } \\
\text { tinggi } \\
\text { - Tahap } \\
\text { pendidikan } \\
\text { rendah } \\
\text { - Kadar penceraian } \\
\text { - Masalah sosial di } \\
\text { kalangan remaja }\end{array}$ & $\begin{array}{l}\text { Kawasan } \\
\text { petempatan tiada } \\
\text { infrastruktur asas } \\
\text { seperti elektrik } \\
\text { dan tandas yang } \\
\text { lengkap } \\
\text { Kualiti } \\
\text { perumahan yang } \\
\text { rendah }\end{array}$ \\
\hline
\end{tabular}

\section{Kerangka strategi pembangunan komuniti}

Cadangan kerangka strategi pembangunan mapan komuniti bagi kajian ini (rujuk Rajah 3) dibentuk setelah pengkaji mengambilkira cadangan konsep komuniti mapan dan hasil penilaian tahap kemapanan komuniti berdasarkan prestasi indikator-indikator. Pengkaji telah mengambilkira indikator yang menunjukkan tahap kemapanan tinggi (bertanda positif) sebagai potensi dan indikator yang menunjukkan tahap kemapanan rendah (bertanda negatif) sebagai masalah atau halangan yang perlu ditangani melalui pembentukan strategi pembangunan komuniti di masa yang akan datang. 
Pembangunan Komuniti Mapan - Konsep \& Indikator

\section{Komuniti}

Aktiviti Ekonomi Utama Komuniti

- Bertani tradisional/Pertanian pindah (ubi kayu, padi bukit)

- Bekerja buruh (ladang sawit dan getah, kerja kilang)

- Mencari dan menjual rotan dan buluh kasap

- Berniaga (secara runcit)

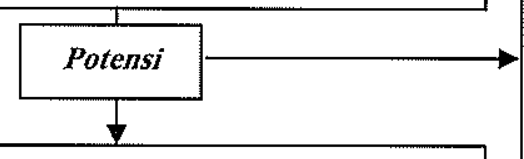

\section{Keunikan dan Potensi}

- Sumber manusia (kemahiran dalam pembuatan kraftangan, memburu, bertani dan mencari hasil hutan)

- Kedapatan tanah subur yang luas dan bersesuaian bagi menjalankan aktiviti pertanian (secara mesra alam dan berskala komersil)

- Seni dan budaya - keunikan cara hidup dan seni tradisional seperti upacara Sewang dan pembuatan barangan kraf

- Sumber alam semulajadi yang belum diteroka pembangunan seperti air terjun dan gunungganang, sesuai bagi aktiviti pelancongan ekologi

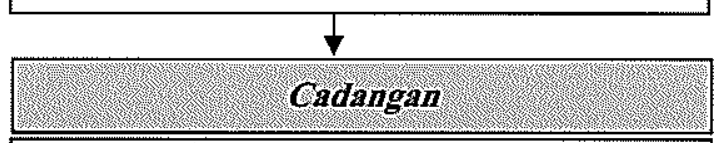

\section{Kerangka Strategi}

- Memelihara atau menggalakkan penerusan amalan-amalan semasa yang mapan

- Mempertingkat/memperbaiki amalan-amalan semasa yang tidak mapan/menunjukkan tahap kemapanan yang rendah

- Membangunkan potensi sedia ada di kawasan kajian melalui perancangan dan tindakan yang mapan

\section{Praktis-Praktis Mapan}

Komponen Kemapanan Sikap

- Pekerjaan sampingan

- Penglibatan ahli keluarga dalam pekerjaan

- Penglibatan dalam aktiviti kebudayaan

- Penglibatan dalam gotongroyong

- Kesanggupan membantu jiran

- Penggunaan bahan kimia dalam pertanian

- Amalan guna semula

- Amalan mengurangkan penggunaan

- Amalan membersihkan halaman rumah

\section{Komponen Kemapanan Sistem}

- Kepatuhan kepada adat dan undang-undang

- Pengasingan bilik anak lelakiperempuan

\section{Komponen Kemapanan Situasi}

- Kadar pengangguran

- Pemilikan tanah

- Aksess kepada perkhidmatan kesihatan

- Pemilikar rumah

- Purata saiz isirumah

- Kemudahan bekalan air

- Kadar pencemaran

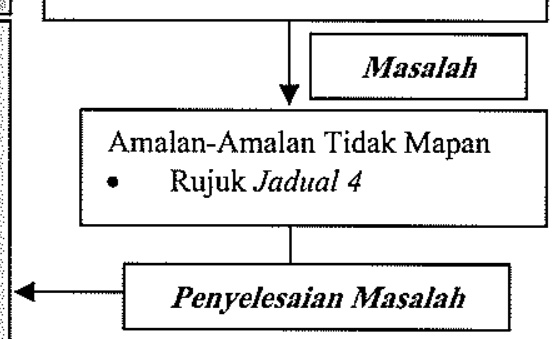

Rajah 3: Kerangka pembentukan strategi pembangunan mapan komuniti 


\section{KESIMPULAN}

Laluan yang dirintis ke arah pembentukan komuniti mapan memerlukan pemahaman yang terjurus tentang bagaimana pelbagai komponen dalam kehidupan komuniti yang kompleks dapat dihubung jalin secara seimbang sehingga menjadi satu unit yang mantap dan begitu melengkapi. Hasil kajian yang dibentangkan dalam artikel ini cuba membentuk kerangka pemahaman yang menyeluruh terhadap pembangunan mapan komuniti Orang Asli luar bandar. Ia termasuklah mengutarakan pandangan alternatif mengenai konsep komuniti mapan, mencadangkan set indikator kemapanan yang khusus bagi komuniti Orang Asli dan membentangkan kerangka pembentukan strategi pembangunan mapan bagi komuniti terlibat berdasarkan maklum balas analisis tahap kemapanan dan hasil sumbang saranan wakil komuniti terlibat. Sudah tiba masanya pihak-pihak yang terlibat dengan proses perancangan dan pembangunan komuniti luar bandar baik penggubal dasar, agensi dan badan pelaksana serta komuniti sasaran melihat dan memahami bahawa jalan ke arah membina komuniti yang mapan adalah begitu mencabar kerana ianya menuntut suatu strategi pembangunan yang tepat serta berkesan.

\section{RUJUKAN}

Copus A.K. and Crabtree J.R. 1996. Indicators of Socio-Economic Sustainability: An Application to Remote Rural Scotland, Journal of Rural Studies. Vol.12. pp. 41-54.

Dyer P., Aberdeen L. And Schuler S. 2003. Tourism Impacts on an Australian Indigenous Community. A Djabugay case study. Journal of Tourism Management. Vol.24. pp.83-95.

Earth Summit 1992. Earth Summit. London: The Regency Press.

Hjorth P. and Bagheri A. 2006. Navigating Towards Sustainable Development: A system dynamics approach. Journal of Future. Vol.38. pp.74-92.

Ibrahim Ngah 2003. "Perancangan Komuniti Mapan: Apakah membina masa depan?" Kertas kerja pada Seminar Kebangsaan Perancangan Bandar \& Wilayah $\mathrm{Ke}-21$, Universiti Teknologi Malaysia, Skudai.

Ibrahim Ngah dan Khairul Hisyam Kamarudin 2004. "Strategi Pembangunan Mampan Komuniti Orang Asli Luar Bandar". Kertas kerja pada Seminar Kebangsaan Perancangan Bandar \& Wilayah Ke-22, Universiti Teknologi Malaysia, Skudai.

Ibrahim Ngah and Khairul Hisyam Kamarudin 2005. "Sustainable Development of Orang Asli Community: A case study of Temiar Community". Paper presented in Ist International Conference on the Indigenous People 2005, 
The Indigenous Population: Survival of Modern Living. Kuala Lumpur. July 3-5 2005.

Jackson T. and Robert P. 2000. A Review of Indicators of Sustainable Development: A report for Scottish enterprise Tayside, Geddes Centre for Planning Research, School of Town Regional Planning, University of Dundee. www.trp.dundee.ac.uk.library/pubs/set.html.

Karjala M.K. and Dewhurst S.M. 2003. Including Aboriginal Issues in Forest Planning: A Case Study in Central Interior British Columbia, Canada. Journal of Landscape and Urban Planning. Vol.64. pp.1-17.

Loomis T.M. 2000. Indigenous Populations and Sustainable Development: Building on Indigenous Approaches to Holistic, Self-Determined Development. Journal of World Development. Vol.28. pp.893-910.

Moffatt I. 1996. Sustainable Development: Principles, Analisis and Policies. The Parthenon Publishing Group.

Musiiwa T. 2002. Sustainability, Indigenous Knowledge and Gender on Smallholder Irrigation Schemes in Manicaland, 1928-1997: Rethinking Peasant Agrarian History in Zimbabwe. Ph.D Thesis. The University of Minnesota.

Nicholas C. 2000. The Orang Asli and the Contest for Resources, Indigenous Politics, Development and Identity in Peninsular Malaysia. Copenhagen: IWGIA.

Peterson J.P. 1997. Indicators of Sustainable Development in Industrializing Countries. Vol.1. Management Response Strategies, Bangi: Penerbit UKM. Pulido J.S and Bocco G. (2003). The Traditional Farming System of a Mexican Indigenous Community: The case study of Nuevo San Juan Parangaricutiro, Michoacan, Mexico. Journal of Geoderma. Vol.111. pp.249-265.

Scott K.(2000). From Sustainable Rural Community to Social Sustainability:

Giving Voice to Diversity in Mangakahia Valley, New Zealand. Journal of Rural Studies. Vol.16. pp.433-446.

Yuan W., James P., Hodgson K., Hutchinson S.M. and Shi C. (2003). Development of Sustainability Indicators by Communities in China: A case study of Chongming, Shanghai. Journal of Environmental Management. Vol.68. pp. 253-261.

Zainuddin Muhammad 1996. "Planning Methods Towards Achieving Sustainable Community". Keynote Address. 15th EAROPH World Congress, Sustainable Communities. Auckland, New Zealand. 3-7 September 1996.

Zainuddin Muhammad 1997. "Perancangan Pembangunan Luar Bandar Mampan". Kertas kerja pada Seminar Kebangsaan Perancangan Bandar \& Wilayah $\mathrm{Ke}-21$, Universiti Teknologi Malaysia, Skudai. 


\title{
PLANNING MALAYSTA
}

Journal of the Malaysian Institute of Planners (2007) V, 131 - 139

\section{BOOK REVIEW}

\author{
By: \\ Shu Charng Yen \\ charngyen.shu@jurong.com
}

\section{Book's Title:}

Allan B. Jacobs, Elizabeth MacDonald, and Yodan Rofé. 2003. THE BOULEVARD BOOK. Boston: M.I.T. Press

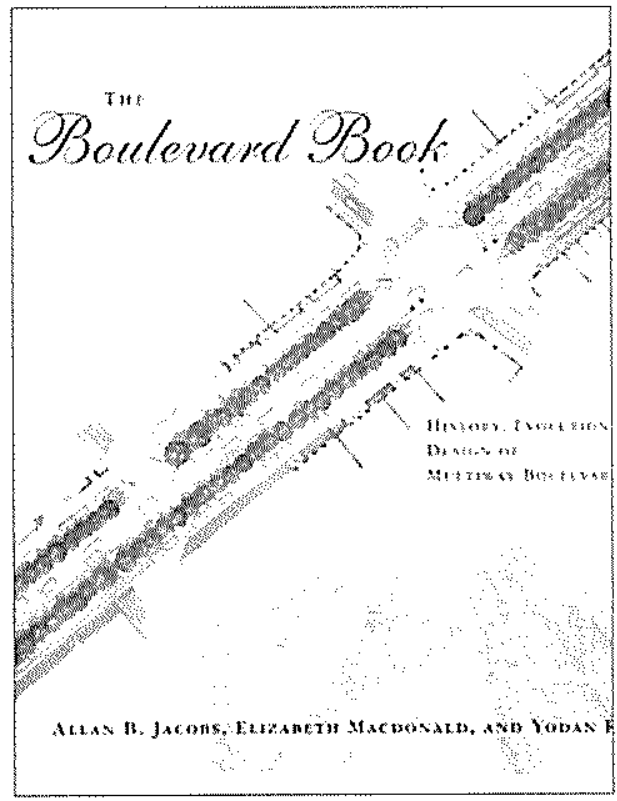

\section{INTRODUCTION}

In the course of our master planning work for new communities, many times we might have tried to come up with new ideas forgetting how invaluable our current urban form which has evolved through the times. Places we are familiar with, our "Jalan Besar", "Jalan Bandar", our "Padang", "Bulatan", "Pesiaran", "Medan Pasar", etc. which offers priceless lessons which can be applied to our new environments. 
Perhaps we are trying to stamp our personal identity into the new places which is within our sphere of influence, as planners, to create, especially with modern technolugy; we can create something out of nothing. For example, cutting an expressway is by blasting through a steep terrain. Of course, not all is bad, some good things can come out of new technology, converting ex-mining land into resorts that appeal and are used by many.

\section{CONTENT OF THE BOOK}

Prof Allan B. Jacobs in his book - The Boulevard Book (2003), has studied and measured many famous urban streets and boulevards, in order to explore what makes great public streets and boulevards and distil lessons from these examples. He has been a member of the Department of City and Regional Planning at the University of California at Berkeley since 1975. The book is beautifully illustrated by hand-drawn plans, road sections and perspective views of the boulevards, streets and places to give a personal touch.

The book has 50 case studies of boulevards including some Asian examples. Finally, it expounds qualities of user-friendly, human scale boulevards and design guidelines for future good boulevards.

According to the book, the classic European boulevard is multi-way. However, it has fallen victim to vehicular traffic, especially in the US. Jacobs reintroduces the concept of a multi-way boulevard, a street which is not only wide and tree-lined, but also separate through traffic from local traffic with wide medians. The central roadway has at least four lanes for automotive traffic, and parallel to it run one-way streets for slower-paced local traffic only. Pedestrians stroll on the large and tree-shaded medians separating the through and local roads. In short, a multi-way boulevard is a "mixed-use public way" (p. 6), serving car drivers, bicyclists, and pedestrians. The most prominent and best-preserved examples of this type of road in the United States are Eastern Parkway and Ocean Parkway in Brooklyn, New York which the authors called "wonderful, human, community places".

The book argues that boulevards could play an important role in revitalising blight by getting people back in the same places.

Our local major thoroughfares are roughly the equivalent with the boulevard with the major arterial serving the fast-moving traffic, with service roads serving the commercial buildings or housing areas flanking the thoroughfare. 
However, our thoroughfares could be more pedestrian-friendly and lined with shade-providing trees.

The book shows how multi-way boulevards relate to many issues that are central to urban life, including livability, mobility, safety, economic opportunity, mass transit, and open space.

A selection of the boulevards studied is:

\begin{tabular}{|c|c|c|c|c|c|c|c|c|}
\hline & & Length & $\begin{array}{c}\text { Width of } \\
\text { road } \\
\text { reserve }\end{array}$ & $\begin{array}{c}\text { Width of } \\
\text { carriageway } \\
\text { (inc median) }\end{array}$ & $\begin{array}{c}\text { Width of } \\
\text { Access } \\
\text { lane }\end{array}$ & \begin{tabular}{|c|} 
Tree- \\
planting \\
interval @ \\
median
\end{tabular} & $\begin{array}{l}\text { Width of } \\
\text { Side } \\
\text { planting } \\
\text { strip }\end{array}$ & Comments \\
\hline & \multicolumn{8}{|l|}{ INDIA } \\
\hline 1 & $\begin{array}{l}\text { C.G. Road, } \\
\text { Ahmedabad, } \\
\text { Gujerat }\end{array}$ & $1.6 \mathrm{~km}$ & $30.4 \mathrm{~m}$ & $13.1 \mathrm{~m}$ & $6.2 \mathrm{~m}$ & Im width & & $\begin{array}{c}3.8 \mathrm{~m} \\
\text { angled } \\
\text { parking }\end{array}$ \\
\hline 2 & $\begin{array}{l}\text { Chelmsford } \\
\text { Rd, New } \\
\text { Delhi }\end{array}$ & $.8 \mathrm{~km}$ & $32.3 \mathrm{~m}$ & $12.2 \mathrm{~m}$ & $5.5 \mathrm{~m}$ & & $3 m$ & \\
\hline 3 & \begin{tabular}{|l|} 
Dr Zakir \\
Hussain Rd
\end{tabular} & $2 \mathrm{~km}$ & $36 \mathrm{~m}$ & $16.5 \mathrm{~m}$ & & & $2.4 \mathrm{~m}$ & \\
\hline 4 & $\begin{array}{l}\text { Katsurba } \\
\text { Ghandi } \\
\text { Marg }\end{array}$ & $1.8 \mathrm{~km}$ & $37.8 \mathrm{~m}$ & $15.8 \mathrm{~m}$ & $4.3 \mathrm{~m}$ & - & $\begin{array}{c}6.7 \mathrm{~m} \text { (inc } \\
\text { walkway- } \\
\text { layby) }\end{array}$ & \\
\hline & \multicolumn{8}{|l|}{ VIETNAM } \\
\hline 5 & $\begin{array}{l}\text { Pasteur } \\
\text { Boulevard } \\
\text { Ho Chi } \\
\text { Minh City }\end{array}$ & $3 \mathrm{~km}$ & $18.9 \mathrm{~m}$ & $7.3 \mathrm{~m}$ & $\begin{array}{c}2.4 \mathrm{~m} \mathrm{(2-} \\
\text { wheelers) }\end{array}$ & \begin{tabular}{|c|} 
Keruing/ \\
Bo Chet \\
$8.5 \mathrm{~m}$ apart
\end{tabular} & $1.8 \mathrm{~m}$ & $\begin{array}{c}\text { One way } \\
\text { for cars \& } \\
\text { buses; } \\
\text { other for } \\
2 \text {-wheelers }\end{array}$ \\
\hline 6 & $\begin{array}{l}\text { Boulevard } \\
\text { Ton Doc } \\
\text { Thang }\end{array}$ & $2 \mathrm{~km}$ & $39.0 \mathrm{~m}$ & $7.3 \mathrm{~m}$ & $4.87 \mathrm{~m}$ & $\begin{array}{c}\text { So Khi } 2 \mathrm{~m} \\
\text { apart }\end{array}$ & $2.4 \mathrm{~m}$ & $\begin{array}{c}\text { Abt } 40 \mathrm{~m} \\
\text { tall trees. } \\
\text { Access } \\
\text { lanes for } \\
2- \\
\text { wheelers }\end{array}$ \\
\hline 7 & $\begin{array}{l}\text { Boulevard } \\
\text { Ham Nghi }\end{array}$ & $1 \mathrm{~km}$ & $51.8 \mathrm{~m}$ & $22.6 \mathrm{~m}$ & $6.4 \mathrm{~m}$ & $3.3 \mathrm{~m}$ & $\begin{array}{c}2.4 \mathrm{~m} \mathrm{\&} \\
5.8 \mathrm{~m}(+ \\
\text { walkway) }\end{array}$ & \multirow{2}{*}{$\begin{array}{c}\text { Access } \\
\text { lanes for } \\
2- \\
\text { wheelers }\end{array}$} \\
\hline 8 & Le Loi Blvd & $1 \mathrm{~km}$ & $54.8 \mathrm{~m}$ & $18.3 \mathrm{~m}$ & $8.2 \mathrm{~m}$ & \begin{tabular}{|c|} 
Keruing \\
$7.9 \mathrm{~m}$ apart
\end{tabular} & $\begin{array}{c}4.3 \mathrm{~m} \mathrm{\&} \\
5.8 \mathrm{~m} \mathrm{(+} \\
\text { walkway) }\end{array}$ & \\
\hline 9 & \begin{tabular}{|l} 
Blvd \\
Nguyen Hue
\end{tabular} & $.8 \mathrm{~km}$ & $60.9 \mathrm{~m}$ & $16.5 \mathrm{~m}$ & $7.9 \mathrm{~m}$ & $1.8 \mathrm{~m}$ & $\begin{array}{c}7.9 \mathrm{~m} \& \\
6.4 \mathrm{~m} \\
(+w a l k w a \\
y)\end{array}$ & \\
\hline & \multicolumn{8}{|c|}{ FRANCE (Paris) } \\
\hline 10 & Avenue & & $38.4 \mathrm{~m}$ & $12.8 \mathrm{~m}$ & & - & $2.1 \mathrm{~m}$ & 3 lanes \\
\hline
\end{tabular}




\begin{tabular}{|c|c|c|c|c|c|c|c|c|}
\hline & Montaigne & & & & & & & $\begin{array}{l}\text { throughtra } \\
\text { ffic } \\
2 \text { access } \\
\text { lanes } \\
\text { roadside } \\
\text { parking } \\
\end{array}$ \\
\hline 11 & $\begin{array}{l}\text { Boulevard } \\
\text { Beaumarcha } \\
\text { is }\end{array}$ & $.55 \mathrm{~km}$ & $35.3 \mathrm{~m}$ & $15.8 \mathrm{~m}$ & - & - & $9.7 \mathrm{~m} \mathrm{x} 2$ & $\begin{array}{l}\text { Planting } \\
\text { strip + } \\
\text { walkway }\end{array}$ \\
\hline & \multicolumn{8}{|c|}{ ITALY (Rome) } \\
\hline 12 & $\begin{array}{l}\text { Via della } \\
\text { Conciliazion } \\
\text { e }\end{array}$ & $.4 \mathrm{~km}$ & $45.1 \mathrm{~m}$ & $18.9 \mathrm{~m}$ & $5.2 \mathrm{~m}$ & & $\begin{array}{c}\text { No trees } \\
\text { but } 4.3 \mathrm{~m} \\
\text { strip with } \\
\text { historic } \\
\text { lighting }\end{array}$ & $\begin{array}{l}\text { St Peter's } \\
\text { on axis }\end{array}$ \\
\hline 13 & $\begin{array}{l}\text { Via } \\
\text { Nomentana }\end{array}$ & $1.6 \mathrm{~km}$ & $39.6 \mathrm{~m}$ & $14.0 \mathrm{~m}$ & $3.9 \mathrm{~m}$ & & $\begin{array}{c}2.4 \mathrm{~m} \mathrm{\&} \\
3.6 \mathrm{~m} \\
\end{array}$ & \\
\hline & \multicolumn{8}{|c|}{ PORTUGAL } \\
\hline 14 & $\begin{array}{l}\text { Avenida da } \\
\text { Liberdade, } \\
\text { Lisbon }\end{array}$ & $1.2 \mathrm{~km}$ & $80.46 \mathrm{~m}$ & $14.6 \mathrm{~m}$ & $6.1 \mathrm{~m}$ & $\begin{array}{c}5.5-7.6 \mathrm{~m} \\
\text { apart }\end{array}$ & $\begin{array}{c}5.4 \mathrm{~m} \& \\
7.3 \mathrm{~m}\end{array}$ & $\begin{array}{c}\text { Two } 8.2 \mathrm{~m} \\
\text { walkway } \\
\text { flanks } \\
\text { medians. } \\
5-10 \text { sty } \\
\text { bldgs }\end{array}$ \\
\hline 15 & $\begin{array}{l}\text { Avenida da } \\
\text { Republica, } \\
\text { Lisbon }\end{array}$ & $1.2 \mathrm{~km}$ & $53.3 \mathrm{~m}$ & $21.0 \mathrm{~m}$ & $5.5 \mathrm{~m}$ & $\begin{array}{c}1.5 \mathrm{~m} \\
6.4-10 \mathrm{~m} \\
\text { apart }\end{array}$ & $\begin{array}{l}6.1 \mathrm{~m} \text { (inc } \\
\text { carpk) }\end{array}$ & \\
\hline & \multicolumn{8}{|l|}{ SPAIN } \\
\hline 16 & $\begin{array}{l}\text { Avinguda de } \\
\text { Roma, } \\
\text { Barcelona }\end{array}$ & $\begin{array}{l}10 \text { city } \\
\text { blocks }\end{array}$ & $51.2 \mathrm{~m}$ & $12.8 \mathrm{~m}$ & $6.1 \mathrm{~m}$ & & $\begin{array}{c}3.6 \mathrm{~m} \mathrm{\&} \\
12.8 \mathrm{~m}\end{array}$ & \\
\hline & $\begin{array}{l}\text { Paseo de } \\
\text { Recoletos, } \\
\text { Madrid }\end{array}$ & $6.4 \mathrm{~km}$ & $87.8 \mathrm{~m}$ & $19.8 \mathrm{~m}$ & $\begin{array}{c}7.6 \mathrm{~m} \& \\
9.4 \mathrm{~m}\end{array}$ & & & $\begin{array}{c}35 \mathrm{~m} \mathrm{\&} \\
12 \mathrm{~m} \\
\text { median- } \\
\text { walkway }\end{array}$ \\
\hline & \multicolumn{8}{|l|}{ USA } \\
\hline 17 & $\begin{array}{l}\text { The } \\
\text { Esplanade, } \\
\text { Chico, } \\
\text { California }\end{array}$ & $2 \mathrm{~km}$ & $50 \mathrm{~m}$ & $19.5 \mathrm{~m}$ & & $9-11 \mathrm{~m}$ & $3 m$ & \\
\hline 18 & $\begin{array}{l}\text { Grand } \\
\text { Concourse, } \\
\text { NYC }\end{array}$ & & $53.3 \mathrm{~m}$ & $15.2 \mathrm{~m}$ & $10.7 \mathrm{~m}$ & & $2.3 \mathrm{~m}$ & $\begin{array}{c}\text { 4-lane. } \\
\text { Although } \\
\text { impt } \\
\text { arterials, } \\
\text { these } 2 \text { are } \\
\text { historic } \\
\text { landmarks }\end{array}$ \\
\hline 19 & $\begin{array}{l}\text { Ocean } \\
\text { Parkway, } \\
\text { NYC }\end{array}$ & & $64 \mathrm{~m}$ & $21.3 \mathrm{~m}$ & $7.6 \mathrm{~m}$ & & & 6-lane \\
\hline
\end{tabular}




\begin{tabular}{|c|c|c|c|c|c|c|c|}
\hline \multicolumn{8}{|c|}{ ARGENTINA } \\
\hline 20 & $\begin{array}{l}\text { Avenida } 9 \\
\text { de Julio }\end{array}$ & $136.5 \mathrm{~m}$ & $56.7 \mathrm{~m}$ & & & & $\begin{array}{c}\text { 8lanes } \\
\text { each way, } \\
\text { not } \\
\text { pedestrian } \\
\text { friendly }\end{array}$ \\
\hline & \multicolumn{7}{|c|}{ AUSTRALIA } \\
\hline 21 & $\begin{array}{l}\text { Royal } \\
\text { Parade, } \\
\text { Melbourne }\end{array}$ & $59.7 \mathrm{~m}$ & $16.1 \mathrm{~m}$ & $\begin{array}{c}7.3 \mathrm{~m} \& \\
7.6 \mathrm{~m}\end{array}$ & & $10.0 \mathrm{~m}$ & $\begin{array}{c}\text { Bicycle } \\
\text { lane } \\
\text { Moving \& } \\
\text { Rdside } \\
\text { carpark }\end{array}$ \\
\hline 22 & St Kilda Rd & $60.0 \mathrm{~m}$ & $19.5 \mathrm{~m}$ & $9.1 \mathrm{~m}$ & & $\begin{array}{l}5.2 \mathrm{~m} \\
5.8 \mathrm{~m} \\
6.1 \mathrm{~m}\end{array}$ & \\
\hline 23 & $\begin{array}{l}\text { Victoria } \\
\text { Parade }\end{array}$ & $68.8 \mathrm{~m}$ & $14 \mathrm{~m} \times 2$ & $\begin{array}{c}\text { Tramway: } \\
5.5 \mathrm{~m}\end{array}$ & $13.1 \mathrm{~m} \mathrm{x} 2$ & $4.6 \mathrm{~m}$ & $\begin{array}{l}\text { No access } \\
\text { lane for } \\
\text { cars but } \\
\text { tramway } \\
\text { in the } \\
\text { middle }\end{array}$ \\
\hline
\end{tabular}

(Units have been converted from imperial units).

Jacobs' personal favourites include Paseo da Garcia (barcelona), Avenue Montaigne (Paris) and La Ramblas (Barcelona) and San Francisco Boulevard (Sacramento). The book contends that multi-way boulevards are just as safe if not safer than conventionally-designed roads by traffic engineers (Table 3.2 for US Boulevards and Table 3.3 for European Boulevards). Queens Boulevard is cited as being a dangerous boulevard $(60.96 \mathrm{~m}$ wide; 3-lane each way \& 2-lanes each way on the access lanes, capable of 3-lanes and traffic speed equally fast); trees are not prominent; low pedestrian movement. A possible reconfiguration is to widen the median between the main carriageways and narrow down the access lanes to provide one traffic land and 2 parallel parking lanes.

\section{DESIGN GUIDELINES}

The book lists down the following design guidelines for boulevards:

\section{- Location, context and use}

Where there is a need to carry both through traffic and local traffic, especially if the through traffic is faster than the local traffic and there is potentially, a conflict between both

At major significant elements in the city; the special places. 
Where there is a significant volume of pedestrian movement, such as commercial streets, streets with high residential density, streets with public transit or those with significant presence of public buildings.

\section{- Buildings that face the boulevard}

The difference between a boulevard and an ordinary arterial street is that access to buildings fronting boulevards is not limited from access lanes to encourage pedestrian accessibility and improve visibility of commercial areas.

When a boulevard borders a public park or civic institution and parking is not desired, it can be one-sided with an access street only on one side with ordinary buildings. A wider pedestrian promenade might front a park or civic institution and reinforce its importance. If one side has buildings fronting it and the other is a commercial development surrounded by parking lots, a one-sided boulevard with a pedestrian promenade along the parking lot frontage can mitigate the impact of the open parking lot. However, Jacobs mentions that the latter can be replaced by buildings facing the boulevard and an access road.

\section{- Boulevard realm and overall size}

The multi-way boulevard comprises two distinct realms: the fast through
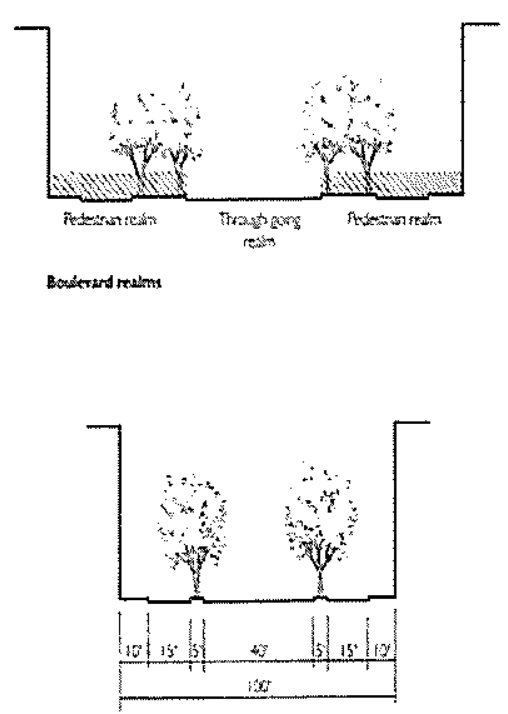

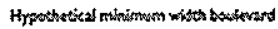

Jacobs, MacDonald, Roie, The Boulevard

traffic realm and the pedestrian realms of continuous tree-lined medians separating them, the narrow access roads and the sidewalks. This treeplanted median can be of varying widths.

The proportion of the two realms on a good boulevard is roughly $1: 1$ up to two-thirds of the width for the medians, access roads and sidewalks as shown in the book's Table 5.1 and the diagram (attached). From the analysis in the book, $30.48 \mathrm{~m}$ is the minimum with a dual 2-lane of $3.2 \mathrm{~m}$ each lane; access roads of $4.9 \mathrm{~m}$ for passing and parking lane; two medians $1.5 \mathrm{~m}$ each and sidewalks of $2.4 \mathrm{~m}$ wide each. 
Boulevards, narrower than $30.48 \mathrm{~m}$, is possible but might not have $7.6 \mathrm{~m}$ to accommodate one moving lane and one parking lane.

\section{- The Through-going realm}

A minimum dual of 2-lane boulevard to serve the through-going realm up to a maximum of dual 3-lanes for greater flexibility.

Overall width of central realm should be balanced with overall right-of-way, traffic capacity desired, and need for safe crossings by pedestrians. Widths exceeding $25 \mathrm{~m}$ should be avoided due to safety of pedestrians crossing it.

\section{- The pedestrian realm}

A minimum of $9.1 \mathrm{~m}$ pedestrian realm comprising $1.5 \mathrm{~m}$ tree-planting, $4.6 \mathrm{~m}$ access lane each direction and a $3 \mathrm{~m}$ sidewalk is advocated. This is to allow pedestrians to walk on the access road and on the median if the pedestrian traffic is heavy

Access road can be treated with slight change in elevation from the centre realm (carriageway) and rougher surface material to promote slow-moving pace.

\section{- Continuous tree-lined medians}

Continuous tree-lined medians protect the pedestrian realm from the central through traffic. A median is the area between the central through traffic realm and the pedestrian realm. It does not refer to the central median in between the two directions of through traffic.

Medians should be provided with bus-stops, subway access points, regularlyspaced benches, pedestrian-scaled street lights, at intervals not exceeding $15.2 \mathrm{~m}$, water fountains, kiosks, public toilets, café seating, flower stands.

\section{- Rows of Trees and Tree Spacing}

Trees are the defining characteristic of all boulevards and have 3 functions:

- They define the various boulevard realms as in trees at medians.

- They break down the visual scale of wide right-of-ways

- They create a pleasant environment for pedestrians and drivers alike.

Trees at medians should be closely spaced and continue all the way to the intersection. The maximum spacing is $10.6 \mathrm{~m}, 7.6 \mathrm{~m}$ is preferable. The spacing should be such that the branches can form a continuous overhead canopy. 
Trees should be deciduous as they provide shade in the summer and yet allow sun in the winter.

\section{- Public transport}

Multi-way boulevards are a natural location for public transport

Bus lanes can be designated along the carriageway. If light rail is incorporated into the boulevard, it can run on the central median.

\section{- Parking}

On-street parking is critical on the access roads. It discourages cars from

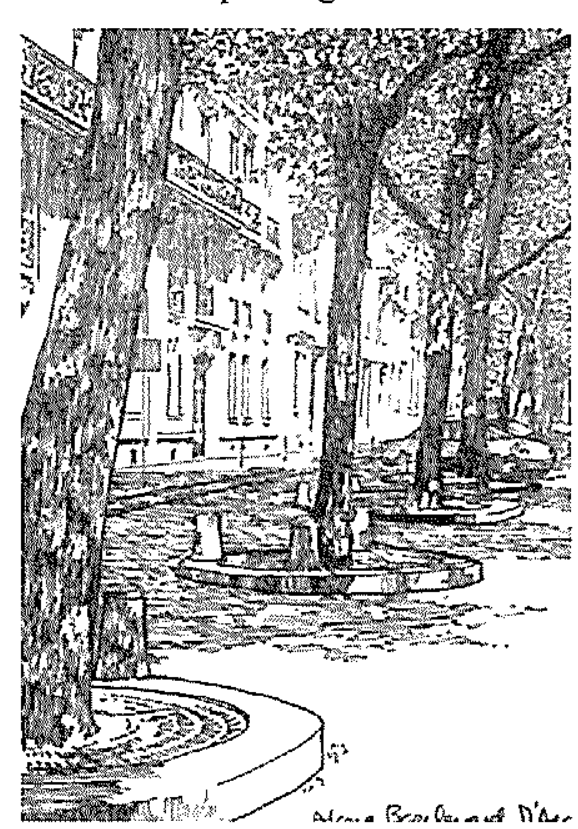

Boulevard de Strasbourg. Jacobs, MacDonald,

Rofe, The Boulevard Book, 2003 speeding on access roads, gives direct access to buildings fronting the boulevard, increases the pedestrian movement along a street and encourages street-oriented development. Parking should be avoided in the carriageway.

Parking lanes should be narrow, about $1.8 \mathrm{~m}$ or $2.1 \mathrm{~m}$ up to a maximum of $2.4 \mathrm{~m} /$ $2.7 \mathrm{~m}$. Angled parking can be incorporated into wide medians (Boulevard de Strasbourg).

If more parking is needed near boulevard, it can be underground parking under the carriageway with entries/ exits for cars under the access roads and from medians for pedestrians without disrupting the pedestrian character of these spaces.

\section{- Lane Widths}

Ideally, $2.7 m-3.3 m$ for lanes on the carriageway and $2.1 m-2.7 m$ for the access roads. The access roads function as local roads and design to encourage slower traffic speeds while the lanes on the carriageway should be wider but not too much as to encourage speeding.

\section{- Bicycle Lanes}

Local bicycle traffic can be incorporated into the access roads. Designated bicycle lanes for faster commuter bicycles can be provided in the median on 
a designated path or a narrow first lane in the carriageway, next to the median.

\section{CONCLUSION}

The book presents the controversial idea that pedestrians and cars can mix and interact and this encourages a vibrant and safer community for all. Perhaps we have let the car control us too much and have accommodated the rising reliance of the cars to get us anywhere and everywhere and as close as possible to our destination.

According to Jacobs' findings, when cars are more fully aware of and integrated into the pedestrian realm, both pedestrians and drivers are safer as seen in some European examples.

"If we can develop and design streets so that they are wonderful, fulfilling places to be - community-building places, attractive for all people - then we will have successfully designed about one-third of the city directly and will have had an immense impact on the rest."- Jacobs

Additionally, referring to the book's design guidelines on the importance of trees, especially deciduous trees and how they are the defining characteristic of all boulevards, I would like to appeal to local authorities and developers to see the need for shade-providing trees. My several work trips to North China from winter to summer make me appreciate our majestic Pukul Lima, stately tembusu and evergreen angsana not forgetting our fragrant Chempaka putih and frangipanni. The trees there grow much slower than ours. The Northern Chinese know it is spring when trees bud. We live in a lush tropical environment and should capitalise on our luxuriant flora in our towns, new developments, housing gardens, in front of the ubiquitous shop office, in our car parks, industrial parks.

The book mentioned that the Pasteur boulevard (Ho Chi Minh and the narrowest boulevard discussed) have Dipterocarpus alatus rex (kerning) along the medians. Isn't it great if our central medians are lined with magnificent meranti, jelutong, pulai, and balau that tower over the street lighting? Not just the jati trees along our N-S expressway? How about planting a rainforest in our Open Spaces in the urban areas? And put swings on the Tembusu \& build tree houses in these Open Spaces for our children to play in? 
PLANNING MALAYSIA

Journal of the Malaysia Institute of Planners (2020)

\section{NOTES TO CONTRIBUTORS AND GUIDELINES FOR MANUSCRIPT SUBMISSION}

\section{INTRODUCTION}

The Journal of the Malaysian Institute of Planners or PLANNING MALAYSIA is a multidisciplinary journal related to theory, experiments, research, development, applications of ICT, and practice of planning and development in Malaysia and elsewhere.

The objective of the journal is to promote the activity of town planning through dialogue and exchange of views concerning professional town planning practice. PLANNING MALAYSIA will welcome any news, feature articles, or peer reviewed (including book reviews, software review, etc.) articles for publication. All articles should be original work by the authors. Articles, views and features will not be taken to be the official view of the Malaysian Institute of Planners (MIP) unless it carries the name of MIP as the author. This is to encourage open discussion on diverse issues and opinion for the advancement of town planning practice. Articles and contributions will be accepted from MIP members and non-members worldwide.

In year 2010, PLANNING MALAYSIA Journal has been indexed in SCOPUS. Previous issues of PLANNING MALAYSIA Journal can be viewed on the MIP website.

\section{SUBMISSION OF MANUSCRIPTS}

Manuscript should be emailed to pmjournal@gmail.com. Manuscript should ideally be in the range of 8-10 pages long. Each manuscript should have a title page and an abstract of about 150 words. The title page should contain the title, full name(s), designation(s), organizational affiliation(s), a contact address, and an email address. All manuscripts are received on the understanding that they are not under concurrent consideration at another journal. Exclusive copyright of accepted manuscripts shall be assigned to the Publisher (i.e. the MIP), and in consideration for this, one copy of the current Journal will be provided for each article. Additional reprints of article can be ordered, at cost, by the author(s). PDF format of the article (if available) can be obtained from the Publisher.

\section{LAYOUT}

Manuscript should be typed in single spacing (including footnotes, endnotes and references) on one side of the paper only (preferably A4) with the following margins: right and left $-4.25 \mathrm{~cm}$, top $-5.5 \mathrm{~cm}$ and bottom $-5.2 \mathrm{~cm}$ (including header $-4.5 \mathrm{~cm}$ and footer $-4.3 \mathrm{~cm}$ ) in 11 point Times New Roman font. Footnotes should be numbered consecutively and placed at the end of the manuscript. Footnotes should be kept to a minimum. Tables and diagrams should be provided in the text. References should follow the APA (6th Edition) referencing format. All foreign words must be typed and transliterated. The Editorial Board reserves the right to change the transliteration of all historical names, titles and non-English terminology to bring them into conformity with its own style. 


\section{USE OF FORMULA, FIGURES AND TABLES}

Formula (mathematical formula) should be used only when necessary and the CONCLUSION derived must be explained and made intelligible to a non-mathematical reader. Wherever possible, authors are encouraged to place the mathematical parts of the article in an appendix. In cases of empirical articles, authors are expected to make readily available a complete set of data and any specialized computer programs to interested readers.

All illustrations, figures and/or tables in the manuscript must be captioned, in clear black and white (grayscale) and ready for reproduction.

\section{REFEREEING PROCEDURE}

Manuscripts will be acknowledged upon receipt. Only selected (preferred) manuscripts will be reviewed by two (or three) referees in addition to the editors. Editorial decision will normally be made within two to six months, but circumstances beyond control occasionally dictate a longer cycle. If authors are invited to prepare a revision for further consideration, the major issues to be resolved will be outlined and will be forwarded to them as quickly as possible.

\section{ACCEPTED ARTICLES}

Authors of accepted articles will be requested to provide a digital copy of the manuscript, preferably in Microsoft Word to the MIP (the Publisher) via email at pmjournal@gmail.com. MIP will not be responsible for the loss or damage of the digital copy.

\section{COPYRIGHT}

Copyright \& Creative Commons Licence

eISSN: 0128-0945 (C) Year. The Authors. Published for Malaysia insititute of planner.

This is an open-access article under the CC BY-NC-ND license.

The authors hold the copyright without restrictions and also retain publishing rights without restrictions.

\section{Contact:}

Editor-in-Chief

PLANNING MALAYSIA

Journal of the Malaysian Institute of Planners

B-01-02, Jalan SS7/13B, Aman Seri, Kelana Jaya,

47301, Petaling Jaya, Selangor Darul Ehsan, MALAYSIA

Tel: +603 78770637 Fax: +603 78779636

Email: pmjournal@gmail.com

Homepage: www.planningmalaysia.org 


\section{ETHIC STATEMENT}

The Journal of the Malaysia Institute of Planners or PLANNING MALAYSIA is a peerreviewed journal. This statement spells out ethical behaviour of all parties involved in the act of publishing an article for this journal, i.e. the author, the peer-reviewer, the chief editor and editors, and the publisher. This statement is based on COPE's Best Practice Guidelines for Journal Editors. URL: http://publicationethics.org/files/u2 /Best_Practice.pdf

\section{DUTIES OF AUTHORS}

\section{Reporting Standards}

Authors of original research should present an accurate account of the work done as well as an objective discussion of its significance. Data of the research should be represented accurately in the article. An article should contain sufficient detail and references to permit others to replicate the work. Fraudulent or knowingly inaccurate statements constitute unethical behaviour and are unacceptable.

\section{Data Access and Retention}

Authors may be asked to provide the raw data in connection with an article submitted for editorial review, and should be prepared to provide public access to such, if practicable, and should in any event be prepared to retain such data for a reasonable time after publication.

\section{Originality and Plagiarism}

Authors should ensure that they have written entirely original works, and if the authors have used the work and/or words of others this must be appropriately cited or quoted. Such quotations and citations must be listed in the Reference at the end of the article.

\section{Multiple Publication}

An author should not in general publish manuscripts describing essentially the same research in more than one journal or primary publication. Submitting the same manuscript to more than one journal concurrently constitutes unethical publishing behaviour and is unacceptable.

\section{Acknowledgment of Sources}

Proper acknowledgment of the work of others must always be given. Authors should cite publications that have been influential in determining the nature of the reported work.

\section{Authorship of the Paper}

Authorship should be limited to those who have made a significant contribution to the conception, design, execution, or interpretation of the study, and should be listed as coauthors. Others who have participated in certain substantive aspects of the research project, they should be acknowledged or listed as contributors. 


\section{Corresponding Author}

Corresponding author is the author responsible for communicating with the journal for publication. The corresponding author should ensure that all appropriate co-authors and no inappropriate co-authors are included on the paper. All co-authors have seen and approved the final version of the paper and have agreed to its submission for publication.

\section{Acknowledgment of Funding Sources}

Sources of funding for the research reported in the article should be duly acknowledged at the end of the article.

\section{Disclosure and Conflicts of Interest}

All authors should disclose in their manuscript any financial or other substantive conflict of interest that might be construed to influence the results or interpretation of their manuscript.

\section{Fundamental Errors in Published Works}

When an author discovers a significant error or inaccuracy in his/her own published work, it is the author's obligation to promptly notify the journal editor or publisher and cooperate with the editor to retract or correct the paper.

\section{DUTIES OF REVIEWERS}

\section{Contribution of Peer Review}

Peer review assists the chief editor and the editorial board in making editorial decisions while editorial communications with the author may also assist the author in improving the paper.

\section{Unqualified to Review or Promptness}

Any reviewer who feels unqualified to review the assigned manuscript or unable to provide a prompt review should notify the editor and excuse himself/herself from the review process.

\section{Confidentiality}

Manuscripts received for review must be treated as confidential documents. They must not be shown to, or discussed with, others except as authorized by the chief editor. Privileged information or ideas obtained through peer review must be kept confidential and not used for personal advantage.

\section{Standards of Objectivity}

Reviews should be conducted objectively. There shall be no personal criticism of the author. Reviewers should express their views clearly with supporting arguments.

\section{Acknowledgment of Sources}

Reviewers should identify relevant published work that has not been cited by the authors. Any statement that had been previously reported elsewhere should be accompanied by the relevant citation. A reviewer should also call to the chief editor's attention any 
substantial similarity or overlap between the manuscript under consideration and any other published paper of which they have personal knowledge.

\section{Conflict of Interest}

Reviewers should decline to review manuscripts in which they have conflicts of interest resulting from competitive, collaborative, or other relationships or connections with any of the authors.

\section{DUTIES OF EDITORS}

\section{Decision on the Publication of Articles}

The chief editor of the PLANNING MALAYSIA is responsible for deciding which of the articles submitted to the journal should be published. The chief editor may be guided by the policies of the journal's editorial board subjected to such legal requirements regarding libel, copyright infringement and plagiarism. The chief editor may confer with other editors or reviewers in making this decision.

\section{Fair play}

Manuscripts shall be evaluated solely on their intellectual merit.

\section{Confidentiality}

The chief editor/editors and any editorial staff must not disclose any information about a submitted manuscript to anyone other than the corresponding author, reviewers, potential reviewers, other editorial advisers, and the publisher.

\section{Disclosure and Conflicts of Interest}

Unpublished materials disclosed in a submitted manuscript must not be used by anyone who has a view of the manuscript while handling it in his or her own research without the express written consent of the author 


\section{PLANNING MALAYSIA JOURNAL: THE PAST ISSUES}

\section{Volume 1, 2003:}

- Incorporating Sustainable Development Objectives Into Development Plans Through Strategic Environmental Assessment

- Muhammad Faris Abdullah \& Ishak Ariffin

- Environmental Concern In Local Planning Practice

- Foziah Johar

- Ecotourism Planning: Who is Really Responsible?

- Badarudin Mohammed \& Abdul Aziz Hussin

- Towards A Sustainable Built Environment: Environmentally Conscious Planning, Design and Construction

- Norhayati Mahyuddin

- Rural Sustainability: An Examination Of The Practice Of Sustainable Development Principles In A Rural Community In Malaysia

- Ibrahim Ngah

- Managing Urban Development Process By Using Spatial Information System: A Case Study of I-Space

- Alias Abdullah, Muhammad Faris Abdullah \& Fauzan Nordin

- USM Pushing The Frontier Of Town Planning

- Lee Lik Meng

- The Suburbanisation Of The Kuala Lumpur Metropolitan Region

- Jamalunlaili Abdullah 


\section{Volume 2, 2004:}

- Creating The Essence Of Cities: The Putrajaya's Experience - Jebasingam Issace John

- A Study To Evaluate Child-Friendly Neighbourhoods Through A Set Of Child-Friendly Indicators

- Alias Abdullah \& Nik Munerahanim Nik Muhammad

- The Evaluation Of Beaches In Northern Malaysia

- Badarudin Mohammed, Rahmat Azam Mustafa, Adrin Abdullah, A. Ghafar Ahmad \& Shida Irwana Omar

- Urban Land Use Change \& The Langat Basin Ecosystem Health

- Shaharudin Idrus \& Abdul Samad Hadi

- Application Of Land Use Approaches In Controlling Industrial Wastewater Discharge Into River

- Muhammad Faris Abdullah

\section{Volume 3, 2005:}

- Planning Education, Accreditation \& Inter-Professional Links

- Mohd Thalha Alithamby

- Electronic Local Authority Management System

- Tan Thean Siew

- A Study On The Demand Of Spatial Planning \& Decision Support System In Malaysia

- Muhammad Faris Abdullah, Alias Abdullah, Mansor Ibrahim \& Dazilah Abdul Samad

- The Technology Of Asset Management \& Maintenance Culture In Ensuring Sustainable Development

- Khairiah Talha \& KC Leong

- Tessellation Planning \& Honeycomb Housing

- Mazlin Ghazali, Michael J. Durack \& Mohd Peter Davis 